\title{
Effects of Landscape Structure and Agricultural Practices on Farmland Birds in Ontario
}

\author{
By Elena Kreuzberg \\ (Elena Mukhina) \\ Bachelor's Biology, Nizhny Novgorod, Russia, 1980 \\ Doctorate, Conservation Biology, Moscow, Russia, 1993 \\ A thesis submitted to the Faculty of Graduate and Postdoctoral Affairs \\ in partial fulfillment of the requirements for the degree of \\ Master of Science \\ in \\ Biology \\ Carleton University \\ Ottawa, Ontario \\ (C) 2011 Elena Kreuzberg
}


Library and Archives
Canada

Published Heritage Branch

395 Wellington Street Ottawa ON K1A ON4

Canada
Bibliothèque et

Archives Canada

Direction du

Patrimoine de l'édition

395, rue Wellington

Ottawa ON K1A ON4

Canada

Your file Votre référence

ISBN: 978-0-494-81702-5

Ourfile Notre reférence

ISBN: 978-0-494-81702-5

\section{NOTICE:}

The author has granted a nonexclusive license allowing Library and Archives Canada to reproduce, publish, archive, preserve, conserve, communicate to the public by telecommunication or on the Internet, loan, distribute and sell theses worldwide, for commercial or noncommercial purposes, in microform, paper, electronic and/or any other formats.

The author retains copyright ownership and moral rights in this thesis. Neither the thesis nor substantial extracts from it may be printed or otherwise reproduced without the author's permission.
AVIS:

L'auteur a accordé une licence non exclusive permettant à la Bibliothèque et Archives Canada de reproduire, publier, archiver, sauvegarder, conserver, transmettre au public par télécommunication ou par l'Internet, prêter, distribuer et vendre des thèses partout dans le monde, à des fins commerciales ou autres, sur support microforme, papier, électronique etlou autres formats.

L'auteur conserve la propriété du droit d'auteur et des droits moraux qui protège cette thèse. $\mathrm{Ni}$ la thèse ni des extraits substantiels de celle-ci ne doivent être imprimés ou autrement reproduits sans son autorisation.
In compliance with the Canadian Privacy Act some supporting forms may have been removed from this thesis.

While these forms may be included in the document page count, their removal does not represent any loss of content from the thesis.
Conformément à la loi canadienne sur la protection de la vie privée, quelques formulaires secondaires ont été enlevés de cette thèse.

Bien que ces formulaires aient inclus dans la pagination, il n'y aura aucun contenu manquant.

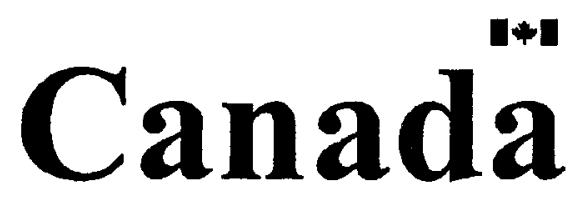




\begin{abstract}
Agricultural expansion and intensification are considered major contributors to biodiversity loss worldwide. However, agricultural landscapes still contain considerable biodiversity, often providing ecosystem services crucial for production.

Farmland birds are recognized in Europe, but not in North America. Based on the EU approach, a list of farmland birds was compiled for Ontario using literature review and expert opinion. Regression analysis for 54 species using point counts from the 2001-2005 Ontario Breeding Bird Atlas with statistics for 181 subdivisions from the 2006 Census of Agriculture was conducted to validate retention and refine categorization of species. The final list for Ontario included 45 species, comprised of 34 specialists (6 row crop, 16 pasture and 12 farmstead) and 11 edge generalists. Landscape structure (especially composition but also configuration and heterogeneity) was more important than practices for richness and abundance of all farmland birds, specialists, generalists and Bird Conservation Region 13 priority species based on statistical comparison of regression models. Subsetting subdivisions (by \% farmland) showed that effects of landscape structure (especially composition) on abundance of specialists and edge generalists varied in relation to agricultural extent and intensity. Effects of practices were also more evident. Because tradeoffs existed across the gradient in landscape composition, farmland bird abundance was optimized when row crop occupied $40 \%$ to $70 \%$ of subdivisions (with 8 to $10 \%$ pasture).

The "farmland bird" approach shows promise for monitoring, assessment and management of agricultural landscapes in North America as in Europe.
\end{abstract}




\section{Acknowledgements}

The current research was implemented under the wise direction of research supervisor, Adjunct Professor of the Carleton University and Landscape Ecologist with Environment Canada, Dr. Kathryn Lindsay. She, as a lodestar, always guided me in my work to finding the optimal ways and solutions. She permanently conducted a monitoring of the project; we discussed all details of the work, from its initial conception and methodical execution to the technical design of the manuscript. She also organized an approbation of study results at the $24^{\text {th }}$ International Congress of the Society for Conservation Biology (Edmonton, $\mathrm{AB}, 03-07.07 .2010$ ). In fact, great and hard work has been done by Dr. Kathryn Lindsay and my gratitude to her may be only great and infinite.

Members of advisory committee Dr. Antoine Morin and Dr. Naomi Cappuccino presented valuable suggestions and recommendations which facilitated the execution of study. I am greatly thankful to them for their help.

Actually, for the opportunity of fulfilment of the project in Geomatics and Landscape Ecology Laboratory I am very much obliged to the Co-director of the Lab, Dr. Lenore Fahrig. Her lectures on landscape ecology had utmost importance for my education, and her great attention to my work was a crucial factor for its implementation. During last two years I always used all possible scientific assistance of the members of GLEL, viz: Dr. Adam Smith, Leif Olson, Dan Bert, Jude Jirard-Phillips, Sarah Overington, and Heather Coffey. I am tremendously grateful to Dr. Lenore Fahrig and all mentioned above colleagues and highly appreciate their help and support. My special thanks to perfect ornithologists Drs. David Kirk, Pierre Mineau and Ted Chesky for their critical revision of candidate farmland bird list for Ontario and our fruitful 
conversations. Dr. David Sharp and Joel Rivard from the Maps \& GIS division of the Carleton University Library assisted me with searching of materials for Census of Agriculture subdivisions and helped very much with technical suggestions and practical materials, particularly with Ontario Pesticide Survey.

The execution of this study would be impossible without comprehensive bird database of the Ontario Breeding Bird Atlas collected by efforts of many volunteers under leadership of Bird Studies Canada. I am deeply obliged to all of them, and especially, to Dr. Denis Lepage and Andrew Couturier for the opportunity to explore this database and to use point count data for testing of my assumptions.

My friends Drs Alexander Mischenko and Olga Sukhanova, Institute of Nature Conservation, Moscow, Russia, Dr. Todd Katzner, Director of Conservation and Field Research in National Aviary, Pittsburgh, USA, Dr. Victoria Kovshar, Zoological Institute of National Academy of Science, Almaty, Kazakhstan, and Dr. Roman Kashkarov, coordinator of IBA program in Uzbekistan supported my efforts sharing information on published works in Russia and Central Asia and practical recommendations. I appreciate their help and encouragements.

Finally, I realize fully that without permanent attentive support of my family this work would be profoundly laboured. Thanks to Alex and patient kids, Daniel and Elina. 


\section{Table of Contents}

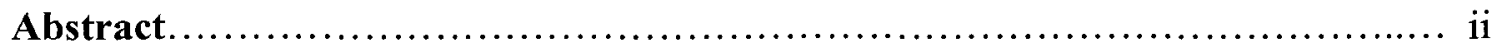

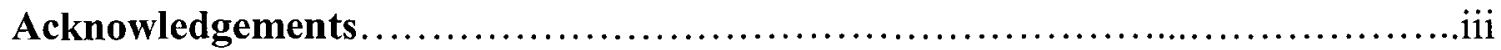

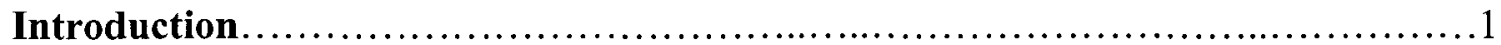

Chapter 1: Continental Comparison..................................... 6

1.1 Effects of farmland structure...................................... 8

1.2 Effects of agricultural practices........................................

1.3 Effects of agricultural expansion, intensification and abandonment.........10

1.4 Agri-environmental schemes.......................................... 12

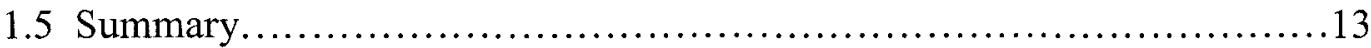

Chapter 2: Ontario Case Study Methods ................................ 15

2.1 Compilation of farmland birds ....................................... 15

2.2 Census of Agriculture data....................................... 15

2.3 Ontario Breeding Bird Atlas data....................................... 16

2.4 Statistical analysis................................................... 17

Chapter 3: Ontario Case Study Results....................................23

3.1 Farmland characteristics............................................... 23

3.2 List of farmland birds for Ontario....................................24

3.3 Bird characteristics .................................................... 26

3.4 Effects of farmland structure and agricultural practices....................27

3.5 Effects of agricultural expansion and intensification ...................... 30

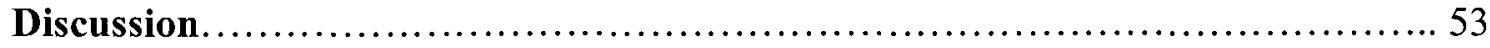

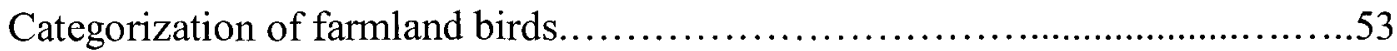

Effects of farmland structure and agricultural practices...........................54

Effects of agricultural expansion and intensification..........................56

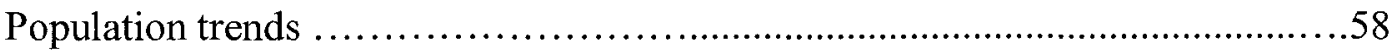

Conservation implications.............................................59

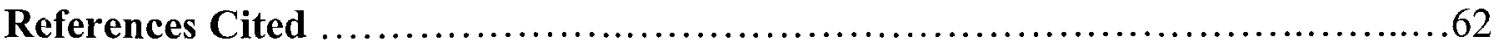

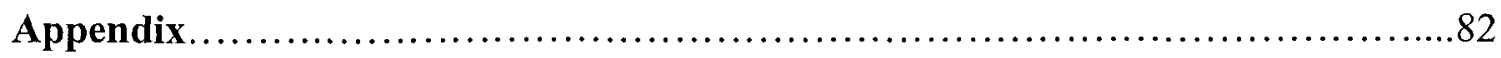




\section{List of Tables}

Table 3.1 Descriptive statistics for explanatory variables across 181 subdivisions in Ontario

Table 3.2 Descriptive statistics for explanatory variables for subdivision subsets in Ontario. .35

Table 3.3 Regression results for candidate farmland bird species in 181 subdivisions

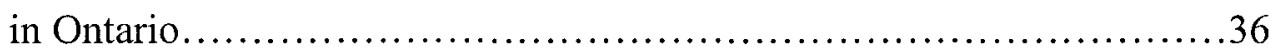

Table 3.4 List of farmland birds for Ontario 39

Table 3.5 Descriptive statistics for bird response variables for 181 subdivisions in Ontario 40

Table 3.6 Descriptive statistics for bird response variables for subdivision subsets in Ontario

Table 3.7 Regression results for bird abundance and richness in 181 subdivisions in Ontario for A. All farmland birds B. Farmland specialists C. Farmland generalists and D. BCR 13 priority species.

Table 3.8 Regression results for farmland bird abundance in 181 subdivisions and in subsets with different agricultural intensity in Ontario.... 


\section{List of Figures}

Figure 1.1 Continental distribution of papers on bird-agriculture relationships ........14

Figure 1.2 Comparison of bird studies in agricultural landscapes of Europe (EU) and North America (NA) .............................................. 14

Figure 2.1 Agricultural subdivisions (subsetted by percent farmland) used in the case study for Ontario.

Figure 2.2 Bird point count density for agricultural subdivisions used in the case study for Ontario

Figure 3.1 Numerical response of farmland bird abundance and richness to farmland structure and practices in 181 subdivisions in Ontario.

Figure 3.2 Abundance-habitat relationship for row crop specialists (6 species) in 181 subdivisions in Ontario.

Figure 3.3 Abundance-habitat relationship for pasture specialists (11 species) in 181 subdivisions in Ontario

Figure 3.4 Relationship between farmland bird abundance and richness per point count in 181 subdivisions in Ontario

Figure 3.5 Relationships between farmland bird abundance and row crop area for 181 subdivisions in Ontario.

Figure 3.6 Modeled responses of farmland birds to farmland composition in Ontario.....52 


\section{List for Appendix}

Table A1 Pearson correlations among explanatory variables.......................82

Table A2 Synopsis of studies on birds and agriculture in North America .............83

Table A3 Candidate list of farmland birds for North America.......................87

Table A4 Characteristics of candidate farmland birds in Ontario.....................89

Table A5 Regression results for abundance of farmland birds on the final list for Ontario (45 species) using A. 181 subdivisions B. subdivisions with 5-40\% farmland C. subdivisions with 40-60\% farmland and D. subdivisions with $60-94 \%$ farmland. 


\section{Introduction}

Agriculture represents one of the most powerful driving forces determining the direction and intensity of biotic processes on Earth (MEA 2005). Agricultural intensification during the second half of the $20^{\text {th }}$ century exceeded in scale all previous agricultural revolutions and has led to a widespread decline in many different wildlife taxa (Benton et al. 2003). In addition to intensification, two other processes have contributed to biodiversity-related conflicts: abandonment of marginally productive land of high habitat value for open-country biodiversity, and expansion of agricultural operations (Heinle et al. 2008).

Agriculture is also considered to be one of the major factors likely to impact biodiversity in the next 50 years (MEA 2005, Pagiola 2010) from direct and indirect effects mediated through deterioration of ecosystem resilience and exacerbation of stresses by climate change (Wallace \& Brklacich 2009, NRC 2010). This is doubly problematic because biodiversity also provides valuable ecosystem services (e.g. pollination, pest control, nutrient cycling) that are important for promoting more sustainable agriculture (MEA 2005). Some recent modeling forecasts the loss of up 50\% of bird species diversity worldwide by 2050 due largely to agricultural expansion (Teyssedre \& Couvet 2007) and attendant loss and degradation of habitat (Walker et al. 2008). A better understanding of the relationships between bird diversity, farming practices and landscape structure at different spatial and temporal scales is still needed to inform mitigation of adverse impacts and implementation of more effective conservation measures to provide for both biodiversity and ecosystem services (McPherson et al. 2008). 
In Canada, agriculture occurs mostly within the southern regions of the country where there are fertile soils and warmer climates. Agricultural expansion has transformed $65 \%$ of the prairies, $18 \%$ of the boreal plains, $9 \%$ of the mixedwood plains (in Ontario and Quebec) and 8\% of other ecozones (AAFC 2009) through conversion of native habitats (e.g., tall-grass prairies, wetlands, savannah, upland woodlands) (OPF 2005). Ontario is one of the largest and most populated provinces of Canada. Due to environmental conditions, the population mainly inhabits the southern extents close to the border with the USA with attendant urban, agricultural and industrial development. Primary agricultural lands (class $1-3$ soils) occupy $12 \%$ or 7.4 million hectares of the province (AAFC 2009) with over 50\% of those primary lands concentrated south of the Canadian Shield (Turvey \& Koney 2006). The most ecologically diverse landscapes occur in southern Ontario along with the most anthropogenic pressure largely from agriculture because it covers a larger area than that of urban and industrial development (OPF 2005). As a result of agricultural development, many natural landscapes, especially those of open country, have been converted to production. For example, tallgrass prairie (historically only in southern Ontario) has been almost completely lost, a pattern mirrored at the continental scale (Sampson \& Knopf 1994).

Birds have been used extensively as indicators of biodiversity status and trends in agricultural landscapes (Burel et al. 1998, Donald et al. 2002, Sauberer et al. 2004, Gaston \& Fuller 2007, Devictor \& Jiguet 2007, Lemoine et al. 2007) for many reasons including: (1) their ecology is well understood; (2) they respond relatively rapidly to environmental changes that are difficult and expensive to measure directly; (3) they have a great resonance with the public and decision makers; (4) they are easily detected 
allowing rapid and extensive data collection including by volunteers; and (5) the indicators are statistically robust, cost effective, relatively simple and easy to update and complementary to other biodiversity indicator (BLI 2004; Padoa-Schioppa et al. 2006). They have been used as focal species (species having spatial and resource requirements that define environmental conditions that provide for the protection of other species) in agricultural landscapes at local and landscape scales (Padoa-Schioppa et al. 2006).

Birdlife International (BLI 2004) has developed Common Bird Indices based on the population trends of bird species representative of various types of habitats in order to track changes in environmental conditions. The European Bird Conservation Council (EBCC 2009) uses a Common Bird Index and its derivative, the Farmland Bird Indicator, to track the ability of landscapes to support wildlife and advocates its use in Europe for conservation and management of bird populations. In the EBCC context, farmland refers to the areas under production within agricultural landscapes. The EBCC (2009) has categorized species occurring in farmland within agricultural landscapes as: "farmland specialists", "farmland generalists" and "other". Farmland specialists are defined as species that largely depend on areas under production within agricultural landscapes; indeed, many are restricted to farmland (Sanderson et al. 2009). They are typically food specialists and require specific types of farmland habitat for breeding or feeding. "Farmland generalists" are species that use the variety of different cover types as supplementary habitat, but equally inhabit adjacent native habitats. These are mostly the widely distributed, omnivorous species that have extended their habitat selection with the emergence of the new ecological niches and high productivity associated with 
farmed landscapes. Birds categorized as "other" are species that only incidentally use farmland adjacent to their remnant native habitats.

The EBCC Farmland Bird Indicator has been adopted by the European Union (EU) as a structural and sustainable development indicator (Scholefield et al. 2010) and is being used to monitor progress in reversing the long-term decline of biodiversity in farmlands. According to recent results, the populations of $66 \%$ of farmland birds (116 species) across 21 countries are declining, at least to some degree, and this decline is more evident for the 36 species of farmland specialists (EBCC 2009). The Farmland Bird Indicator is also being used in land-use planning and decision making to model the response of biodiversity to potential or forecasted changes.

In North America, the Common Bird Indicator has been developed and used by the Audubon Society (2009) to show that many previously common species have experienced severe declines since 1967. The link to changes in farmland has not yet been discerned in part because species have not been categorized in terms of their relationship with farmland. The present study was intended to address this gap by developing the concept of a "farmland bird" for Canada and the USA (hereafter referred to as North America) and testing it in a case study for Ontario.

Because the concept of a "farmland bird" is not yet developed for North America, it was necessary to conduct a literature review of existing work elsewhere, but particularly in Europe, in order to answer the first research question:

What is a farmland bird in North America and more particularly, in Ontario?

The farmland bird list was then refined through expert opinion prior to use in analyses to validate and refine the candidate list. The review of the existing literature was also 
used to conduct a continental comparison of studies between Europe and North America (Chapter 1) and to inform the methods for the empirical case study in Ontario (Chapter 2) aimed at addressing the next two research questions:

$>$ How do landscape structure and agricultural practices affect farmland birds?

What are the effects of agricultural intensification on farmland birds?

The results of the Ontario case study (Chapter 3) were based on relating 2006 Census of Agriculture data (Statistics Canada 2009) to bird data collected by point counts in the 2001-2005 Ontario Breeding Bird Atlas (Cadman et al. 2007). Analyses were conducted at the scale of agricultural subdivisions over a gradient of farming intensity and using a variety of farmland bird response metrics.

The current research is a first effort to apply the "farmland bird" concept to North America to demonstrate relationships with landscape structure and agricultural practices and thereby inform initiatives such as Bird Conservation Region planning and the development of agri-environmental schemes for conservation of biodiversity and the ecosystem services that it provides. In addition, farmland birds could be used to monitor and assess effects of agriculture, and to model effects of projected changes in land-use on biodiversity to inform policy development, planning and decision making. 


\section{Chapter 1 Continental comparison}

The existing literature was reviewed by sourcing papers from two electronic databases (Science Direct: Agricultural and Biological Sciences and JSTOR) using the key words: "farmland bird" and "birds and agriculture". Searching efforts yielded about 500 papers from around the world since the 1950s until present, of which 195 met the following additional criteria for selection:

Analyses of breeding bird-habitat relationships in agricultural landscapes;

Focused on birds as indicators of agricultural effects on biodiversity;

Used statistical models (e.g., General Linear Modeling) for the analysis.

The review showed that the interest in effects of agriculture on birds has increased substantially in the last decade, especially in Europe and North America relative to other continents (Fig. 1.1). The most studies were conducted in Europe (53\% of 195 papers analyzed); North America was next with $28 \%$. In North America, studies covered the most intensively developed agricultural regions in Canada (prairie-pothole and mixedwood plain) and the USA (Great Plains, Midwest, north and central States).

Studies from Europe and North America reflected four crosscutting areas of inquiry related to:

$>$ Effects of landscape (farmland) structure (composition, configuration and heterogeneity) on birds;

$>$ Effects of agricultural practices on birds;

$>$ Impact of land-use change (primarily agriculture intensification and abandonment) on birds; and

$>$ Use of agri-enviromental schemes to mitigate negative impacts on biodiversity. 
The most common bird metrics used as response variables were species richness and species abundance (density or relative) followed by population trend, indicator species, or guilds (ecological groupings) with breeding success being the least common.

Grouping of species as "farmland birds" was commonly used in European studies. In contrast, North American studies were still focused on native habitat associations (e.g., grassland, forest, wetland) rather than on associations with farmland habitats (e.g., crops, pastures, farmstead). This difference reflected the long history of agriculture in Europe compared to North America (Kleijn \& Baldi 2005). The first agricultural revolution (Neolithic revolution) occurred in the Fertile Crescent (including the Mediterranean region) about 10,000 B.C., and in Mesoamerica about 3,500 B.C. (Gupta 2004). According to Cadman et al. (2007), European settlers started clearing lands for agriculture production in southern and eastern Ontario about 150-200 years ago. Prior to that time, the Huron Nation practiced agriculture in only about 200 square kilometres.

In Europe, many bird species are now considered as farmland birds due to their historical relationship with traditional agrarian landscapes (O'Connor \& Shrubb 1986). Their composition is diverse and well known, and includes 173 bird species, more than any other habitat type in Europe (Tucker \& Evans 1997). There are some geographical variations in farmland bird diversity arising from historical distribution patterns of many open grassland species as they followed the spread of agriculture into Europe from the Asian steppes and Mediterranean semi-deserts (O'Connor \& Shrubb 1986). Many forest species have become adapted to remnant woodland edges and plantations in open country and in some regions comprise about $80 \%$ of all farmland birds (O'Connor \& Shrubb 1986). Thus, European farmlands support an important community of forest 
edge as well as open-country species. Currently, farmland provides the breeding and wintering habitats for nearly 120 bird species of conservation concern (Donald et al. 2002). Although not a focus of the current research, farmlands also play an important role in the dynamics of many migrant bird species in Europe (Farina 1989) and in North America (Boutin et al. 1996, Kirk et al. 2001, Ogden et al. 2008).

\subsection{Effects of farmland structure}

Studies conducted on both continents have shown the effect of habitat composition, configuration and heterogeneity of agricultural landscapes on bird species richness and abundance although from different perspectives (Figure 1.2). In Europe the value of farmland mosaics for biodiversity conservation is well recognized, especially those of traditional agrarian landscapes (Calvo-Iglesias et al. 2009). In North America, the primary focus has been on "patch-matrix" effects associated with the amount, patch size, vegetation composition and fragmentation of native habitat by "hostile" intervening production areas leading to the prevailing question of "How much habitat is enough?'(reviewed recently for grasslands by Ribic et al. 2009a). Relatively fewer studies have focused on the importance of farmland composition, configuration and heterogeneity associated with individual crop types, pasture and hayfields, field size, and crop and noncrop diversity and include Freemark et al. (1991), Best et al. (1995, 1998, 2001), Jobin et al. (1996, 2001), Duelli (1997), Vandermeer et al. (1998), Boutin et al. (1999), Perkins et al. (2000), Kirk et al. (2001), Freemark \& Kirk (2001), Giuliano \& Daves (2002), Jones et al. (2005), Woodhouse et al. (2005) and Winter et al. (2006). In Europe, more studies have been devoted to the effects of composition and 
configuration of the farmland mosaic associated with field size, crop composition, and the presence of native habitats within farms (Berg 2002, Benton et al. 2003, Heikkinen et al. 2004, Hietala-Koivu et al. 2004, Belfrage et al. 2005, Piha et al. 2007, Anhstrom et al. 2008, Henderson et al. 2009). Importance of semi-natural habitats (e.g., hedgerows, field margins) to farmland species and avian diversity in farmland has been shown by many studies on both continents (Perkins et al. 2000, Fuller et al. 2001, 2004, Jobin et al. 2001, Kirk et al. 2001).

\subsection{Effects of agricultural practices}

Studies conducted on both continents showed effects of agricultural management on birds including weed control and application of pesticides, time and intensity of agricultural operations, and grazing intensity (Spark et al. 1996, Paskual et al. 1999, Martin \& Forsyth 2003, Chapman et al. 2004, McMaster et al. 2005, Woodhouse et al. 2005, Buckingham et al. 2006, Puckett et al. 2009, Swagemakers et al. 2009). Organic farming is emerging as one of the ways to mitigate the negative effects of chemicalbased farming (Chamberlain et al. 1999, Henderson et al. 2009, Freemark \& Kirk 2001, Beecher et al. 2002, Belfrage et al. 2005, Jones \& Sieving 2006, Piha et al. 2007, Kragten et al. 2008). In both Europe and North America, studies conducted in the last two decades have shown that practices are relatively less important than farmland structure to birds (Chapman et al. 2004, Jobin et al. 1996, Martin \& Forsyth 2003, Mineau et al. 2005, McMaster et al. 2005, Woodhouse et al. 2005, Billeter et al. 2008, Perlut et al. 2008, Henderson et al. 2009, Ribic et al. 2009b, Gabriel et al. 2010). 


\subsection{Effects of agricultural expansion, intensification and abandonment}

In recent times, the most rapid and extensive changes of agricultural lands were observed both in Western Europe and in North America after the Second World War as a result of agricultural expansion and intensification. The main effects included: 1) conversion to agriculture of marginal lands including remnants native habitats such as woodlands, wetlands and grasslands 2) simplification and homogenization of farmland from local to regional scales from production specialization (livestock or cropping), development of monocultures, simplified rotations, , increasing of farm size through tenure consolidation, increasing of field sizes with the removal of field margins and hedgerows, and alteration of hydrological flows from field drainage and irrigation, and 3) intensified management of production areas including increases in chemical inputs (fertilizers and pesticides) and more frequent disturbances such as tillage and mowing and more efficient harvest (less wastage on fields) (O'Connor \& Shrubb 1986, Freemark \& Boutin 1995, Matson et al. 1997, Benton et al. 2003, Herzon et al. 2008).

Sharp declines in birds observed during the last several decades in Europe and North America have been attributed to rapid agricultural intensification (Benton et al. 2003, Murphy 2003, Freemark 2005, Heinle et al. 2008, Herzon et al. 2008) initially as a result of loss of habitat and farmland heterogeneity (Fuller 2000, Benton et al. 2003, Hietala-Koivu et al. 2004, Van Turnhout et al. 2007, Buenestado et al. 2008) followed by more subtle, indirect, adverse effects of increased chemical inputs and mechanisation during the breeding and overwintering seasons (Peach et al. 2001, Anderson et al. 2002, Peterjohn 2003, Newton 2004, Nocera et al. 2005, Herzon \& O' Hara 2007). Since the $1970 \mathrm{~s}$, farmland bird populations have declined by about $0.8 \%$ per year in Western 
Europe and about 0.3\% per year in Eastern Europe (Sotherton 1998; Chamberlain \& Fuller 2000; Donald et al. 2001, 2006; Siriwardena et al. 2001; Chamberlain 2002; Jepsen et al. 2005; Baldi \& Farago 2007; Sirami et al. 2008; Rodriguez \& Wiegand 2009). Farmland specialists in particular have exhibited significant population declines (Noble \& Raven 2002, Kujawa 2002). While farmland birds are still abundant in many Eastern European countries, increasing intensification is beginning to result in population declines similar to those that have occurred in Western Europe (Verhulst et al. 2004, Herzon \& O'Hara 2007). In North America, effects of agricultural intensification have also been linked to landscape transformation (sometimes as a result of land conversion) and farming practices (Freemark 1995, Rodriguez 2002, Martin \& Forsyth 2003, Warren \& Anderson 2005, Askins et al. 2007, Perlut et al. 2008).

Abandonment of marginal farmlands has been observed in many regions of Europe, the eastern United States (Hart 2005) and eastern Canada (OMAFRA 2009). Abandonment in Europe has occurred mostly in mountainous regions (Pueyo \& Begueria 2007) and in former socialistic countries. From $13 \%$ to $20 \%$ of farmland has been abandoned in the Carpathians area of Poland, Slovakia and Ukraine (Kuemmerle et al. 2008), up to $30 \%$ in Estonia (Herzon et al. 2008) and up to $45 \%$ in Russia (Mischenko \& Sukhanova 2008). In Ontario, farmland area declined by almost $13 \%$ between 1976 and 2006 (OMAFRA 2009) largely from abandonment of pastures.

The abandonment of marginal farmlands has had direct adverse effects on biodiversity, birds in particular, from loss of habitat through succession (Nikolov 2010) and increased fragmentation of the remaining farmland area, in addition to indirect effects from changes in the abundance, composition and availability of food resources, 
destruction of drainage systems and land bogging (Mischenko \& Sukhanova 2008). In the USA, grassland bird declines have also been associated with farmland abandonment (Brennan \& Kuvlevsky 2005, Askins 2007).

\subsection{Agri-environmental schemes}

In Europe, agri-environmental schemes have been recognized as an important instrument to mitigate the negative effects of intensive agriculture on biodiversity (Vandermeer et al. 1998, Hietala-Koivu et al. 2004, Kleijn et al. 2004, Vickery et al. 2004, Mattison \& Norris 2005, Donald et al. 2006, Herzon \& O'Hara 2007). They play an important role in the management of biodiversity, focal species and species of conservation concern (Benton et al. 2003, Herzog et al. 2005; Swagemakers et al. 2009). Organic and integrated farming is central in such schemes in conjunction with countryside stewardship (Vickery et al. 2004). Other practices include set-aside schemes, integrated crop management, and arable stewardship pilot schemes (Bracken \& Bolger 2006, Bradbury \& Kirby 2006, Field et al. 2007, Stevens \& Bradbury 2006).

In the USA, the Conservation Reserve Program (CRP) was introduced as an agrienvironmental scheme to reduce soil erosion but has had beneficial effects on biodiversity including birds (Best et al. 1998, Horn \& Koford 2000, Veech 2006, Perlut et al. 2008, Ribic et al. 2009b). Habitat-based standards for biodiversity have recently been developed in Canada under the National Agri-Environmental Standards Initiative (NAESI; McPherson et al. 2008). The NAESI recommendation was retention of $25 \%$ to $30 \%$ of natural habitats within agricultural watersheds to support biodiversity of forest, 
riparian and grassland species. The role of farmlands (i.e. the area under production) for biodiversity conservation and management was not considered by NAESI.

\subsection{Summary}

In reviewing the literature on birds and agriculture in Europe and North America, several major similarities and differences were apparent (Fig. 1.2):

The concept and use of "farmland birds" is not yet developed in North America in contrast to Europe;

Landscape structure (composition, configuration, heterogeneity) has a primary influence on bird diversity. However, in North America, farmlands are typically viewed as a hostile matrix, rather than habitat. Agricultural landscapes are not yet viewed as mosaics with a gradient in suitability among cover types and farming regimes as is the case in Europe;

$>$ Effects of agricultural practices are secondary to those of landscape structure. Many practices, especially chemical inputs and mowing, have adverse effects, some of which can be mitigated by changes in farming regime (e.g., organic farming);

$>$ Land-use changes (expansion, intensification and abandonment) are affecting bird populations on both continents;

$>$ Agri-environmental schemes on both continents are conserving biodiversity and thereby sustaining ecological services in farmland. However, the application of such schemes explicitly for biodiversity conservation in North America has not yet occurred. Nor is the role of farmlands as a base for conserving birds yet a focus of North-American studies. 


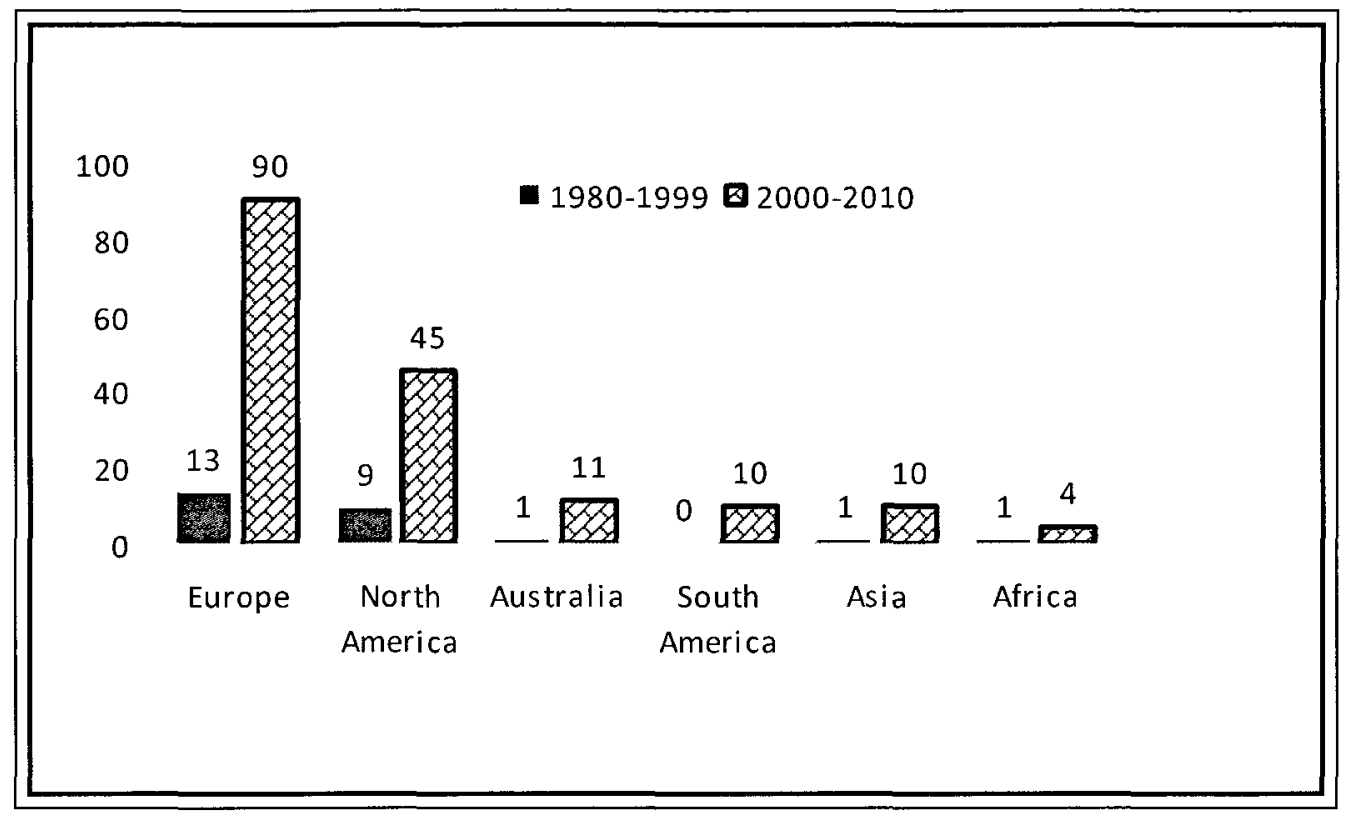

Figure 1.1 Continental distribution of papers reviewed on bird-agriculture relationships.

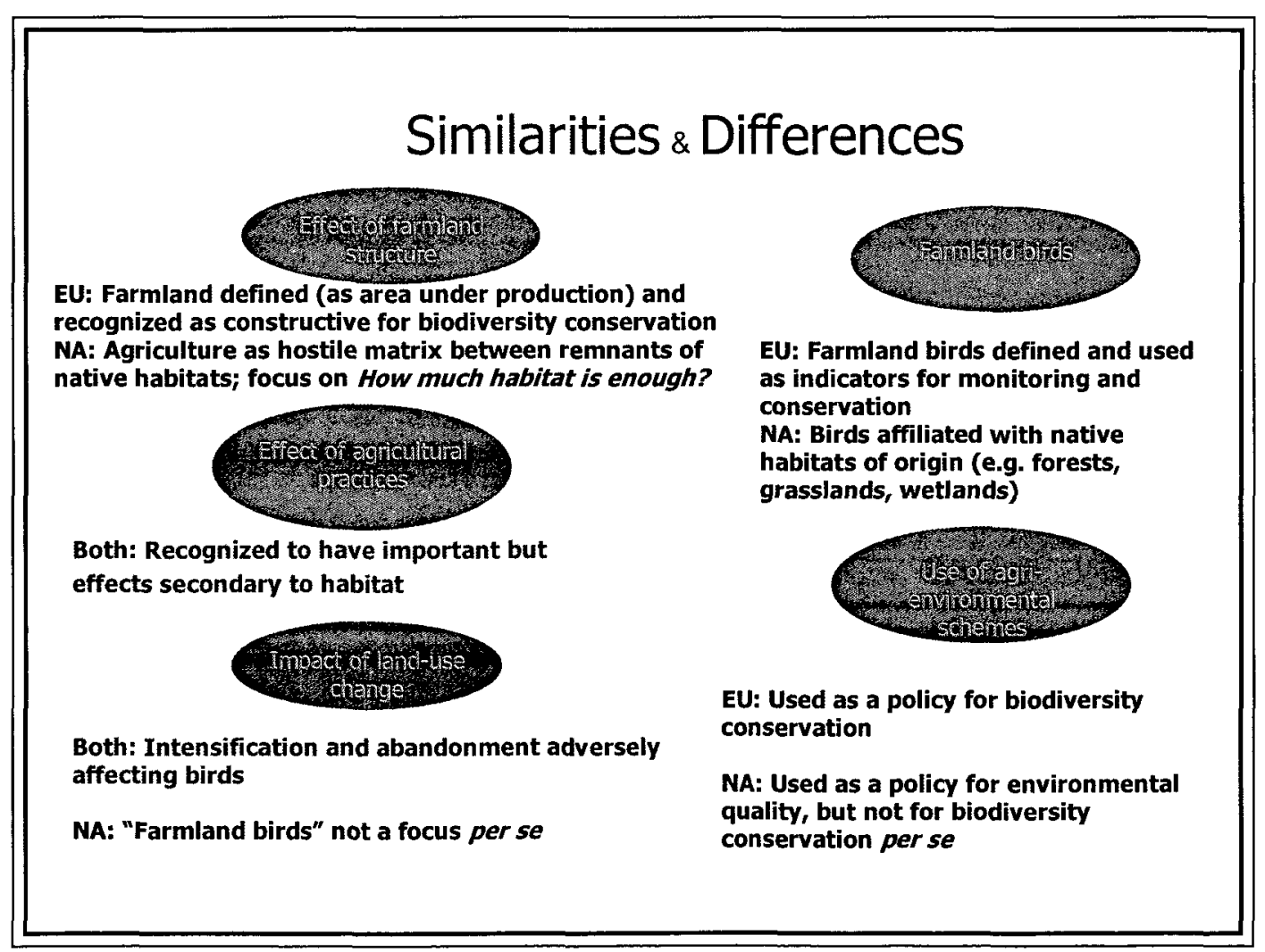

Figure 1.2 Comparison of bird studies in agricultural landscapes between Europe (EU) and North America (NA). 


\section{Chapter 2: Ontario Case Study Methods}

\subsection{Compilation of farmland bird lists}

A literature review (Appendix Table A2) was conducted to compile and characterize a candidate list of farmland birds for North America (Appendix Table A3). Following the EBBC (2009) guidelines, species were classified as "farmland specialists", "farmland generalists" or "other". Farmland specialists were species primarily associated with only one habitat (e.g., row crop, pasture or farmstead). Farmland generalists were species associated with a variety of habitats including native remnants (trees, woods, grasslands, wetlands or their edges), row crop, pasture and farmstead. The candidate list for Ontario (Appendix Table A4) included only farmland generalists or specialists that were detected in the most recent Ontario Breeding Bird Atlas (Cadman et al. 2007) and validated in reviews by six local bird experts.

\subsection{Census of Agriculture data}

The 2006 Census of Agriculture (Statistics Canada 2009) was the source of farmland and agricultural practice information. There were 269 subdivisions in Ontario. Subdivisions with 5\% - 94\% of farmland area were used for analysis. Fourteen variables derived from the subdivision statistics had high loadings and relatively low colinearity based on Principal Component Analysis (PCA).

Farmland composition had six variables (percent area of each subdivision): row crop, natural pasture, seeded pasture, summer fallow, farmstead and native remnants. Row crop included corn, soybean, spring/winter wheat, oats, barley, and other field crops; natural pasture included areas used for pasture that have not been cultivated and 
seeded; seeded pasture was grazeable land that has been improved from its natural state by seeding, draining, fertilizing and weed control and includes hay and fodder crops; summer fallow was cultivated land left free of vegetation for one growing season; farmstead included roads, native remnants were within farmland only.

Farmland heterogeneity was measured as a Shannon-Wiener diversity index using the 6 composition variables. Crop heterogeneity was measured as a Shannon-Wiener diversity index using statistics for 24 crop types.

Farmland configuration had two variables: average farm size (farmland area divided by the number of farms per subdivision) and average crop per farm (crop area divided by the number of farms per subdivision).

Agricultural practices had four variables: intensity of livestock grazing, pesticide input, fertilizer input and machinery per farm. Grazing intensity was the total number of "grazing" animals (cows, horses, sheep, goats) divided by the area of natural pasture per subdivision. Machinery per farm was a count of machinery used for production (e.g., tractors, mowers, combines) divided by the number of farms per subdivision. Pesticide input was a percent based on the summed area treated with herbicides, fungicides or insecticides divided by the area of row crop plus seeded pasture per subdivision. Fertilizer input was a percent based on the summed area treated with fertilizers divided by the area of row crop plus seeded pasture per subdivision.

\subsection{Ontario Breeding Bird Atlas data}

The point count data of the Ontario Breeding Bird Atlas (OBBA) survey conducted in 2001-2005 (Cadman et al. 2007) was used as the source of information on 
bird species, richness and abundance. Each $10 \times 10 \mathrm{~km}$ atlas square had 50 points randomly placed on roadsides (excluding provincial highways) at least $500 \mathrm{~m}$ apart. The proportional representation of habitats in the sample was evaluated against the habitat distribution for the atlas square and off-road points were added for under-sampled habitats. Points were numbered 1-50 with the first 25 to be covered by surveyors; if a point could not be surveyed then it was replaced by the next point in the sequence.

Point were surveyed for birds in good weather during the peak of the breeding season (May 24 - July 10) between dawn and 5 hours after by the collective efforts of thousands of experienced volunteers across Ontario (Cadman et al. 2007). All birds seen and heard during 5 minutes within and beyond $100 \mathrm{~m}$ from observer were recorded. For the purpose of this study, the unlimited-distance point count data for each species on the candidate list of farmland birds were used for analysis.

\subsection{Statistical analysis}

The set of agricultural subdivisions selected was overlaid with OBBA point count locations. Subdivisions that had a bird survey effort less than 1 point count per 500 hectares were removed, leaving 181 subdivisions (Fig. 2.1) with 29,116 point counts (Fig.2.2) for analysis. The dataset was also partitioned into subdivision subsets (Fig.2.1) with $5-39.9 \%$ farmland (59 subdivisions), 40-59.9\% (54 subdivisions) or $60-94 \%$ (68 subdivisions) for analysis of effects of agricultural intensification.

All statistical analyses were conducted in SPSS. General linear modeling (GLM) was used to explore the relationship between farmland birds and landscape structure and farming practices using regression analysis (Grafen \& Hails 2002). Best- fitted models 
were selected based on the Akaike Information Criteria (AIC) corrected for small sample size (i.e., $<100)$ (Akaike 1974) and significance $\left(p \leq 0.05\right.$ ). The adjusted $\mathrm{R}^{2}$ coefficient of determination (as a percent or proportion) was also used as a goodness-offit measure (Grafen \& Hails 2002).

Regression models for candidate farmland birds: Analyses were conducted to examine the validity of the inclusion and specialist or generalist categorization of species in Ontario. Multiple regression with forward selection was used with the 181 subdivision dataset, all explanatory variables and the abundance of individual species (mean number of birds per point count per subdivision). If that failed, backward selection was used (which was the case for 3 species). Of the 66 candidate farmland birds (Appendix Table A4), 54 species had sufficient data for analysis. Based on the results, some species were removed from the candidate list and some species were recategorized. Model results were also used to categorize habitat association for specialist species based on the strength of their association with row crop, pasture, or farmstead; and generalists on their association with habitat edges.

Species were also categorized in relation to their priority for conservation in Bird Conservation Region (BCR) 13 from the list in OPF (2005) refined with information provided by the Canadian Wildlife Service (Ken Tuininga pers. comm. 2010). BCR 13 covers the same region as the Census of Agriculture subdivisions selected for analysis. The species included in the current study represent $12 \%$ of all landbirds that regularly occur in southern Ontario. Some BCR 13 priority species are of concern continent-wide and have important populations in southern Ontario (e.g., Short-eared Owl). Many are relatively abundant and widespread but are declining rapidly with continued declines a 
strong possibility (e.g., Eastern Kingbird, Brown Thrasher, Vesper Sparrow, Eastern Meadowlark). Other species are listed because southern Ontario has a high global responsibility for the species' population in combination with other concerns (e.g., Northern Harrier, Bobolink, Baltimore Oriole). BCR 13 is also home to many of Canada's, and Ontario's, listed Endangered and Threatened species (e.g., Northern Bobwhite, Barn Owl, Loggerhead Shrike, Henslow's Sparrow), which are also included as priority species.

Regression models for farmland birds: To explore alternative hypotheses of effects of landscape structure and agricultural practices on farmland birds, best-fit regression models were produced using the 181 subdivision dataset for explanatory variables grouped by composition, configuration, heterogeneity, agricultural practices or all combined. For the latter group, the best-fit model (i.e., the most parsimonious model) was used as the basis for comparison and is hereafter referred as the "base" model. For each model, a proportional partial regression coefficient (PPRC) was calculated for each variable as a strength metric (as proposed by Smith, 2010) and tabled in relation to composition, configuration, heterogeneity or agricultural practices. The PPRC was calculated by multiplying the regression coefficient in the model by the range in variation for the explanatory variable in the dataset used. The result is interpreted as a numerical change per point per subdivision in response to the observed variability of an explanatory variable.

Mean abundance and/or mean richness per point count per subdivision were analysed for all farmland birds, specialists, generalists and BCR 13 priority species. 
Regression models for agricultural expansion and intensification: Best-fit regression models using all explanatory variables were produced for abundance (mean number of birds per point count per subdivision) of edge farmland generalists, BCR 13 priority species, farmland specialists, row crop specialists, and pasture specialists using subdivisions subsetted by percent farmland. For each base model, the PPRC was calculated for each explanatory variable and tabled by composition, configuration, heterogeneity and practices. Modelled abundances were graphed against row crop because it was the most extensive cover type and was significant in many base models. 


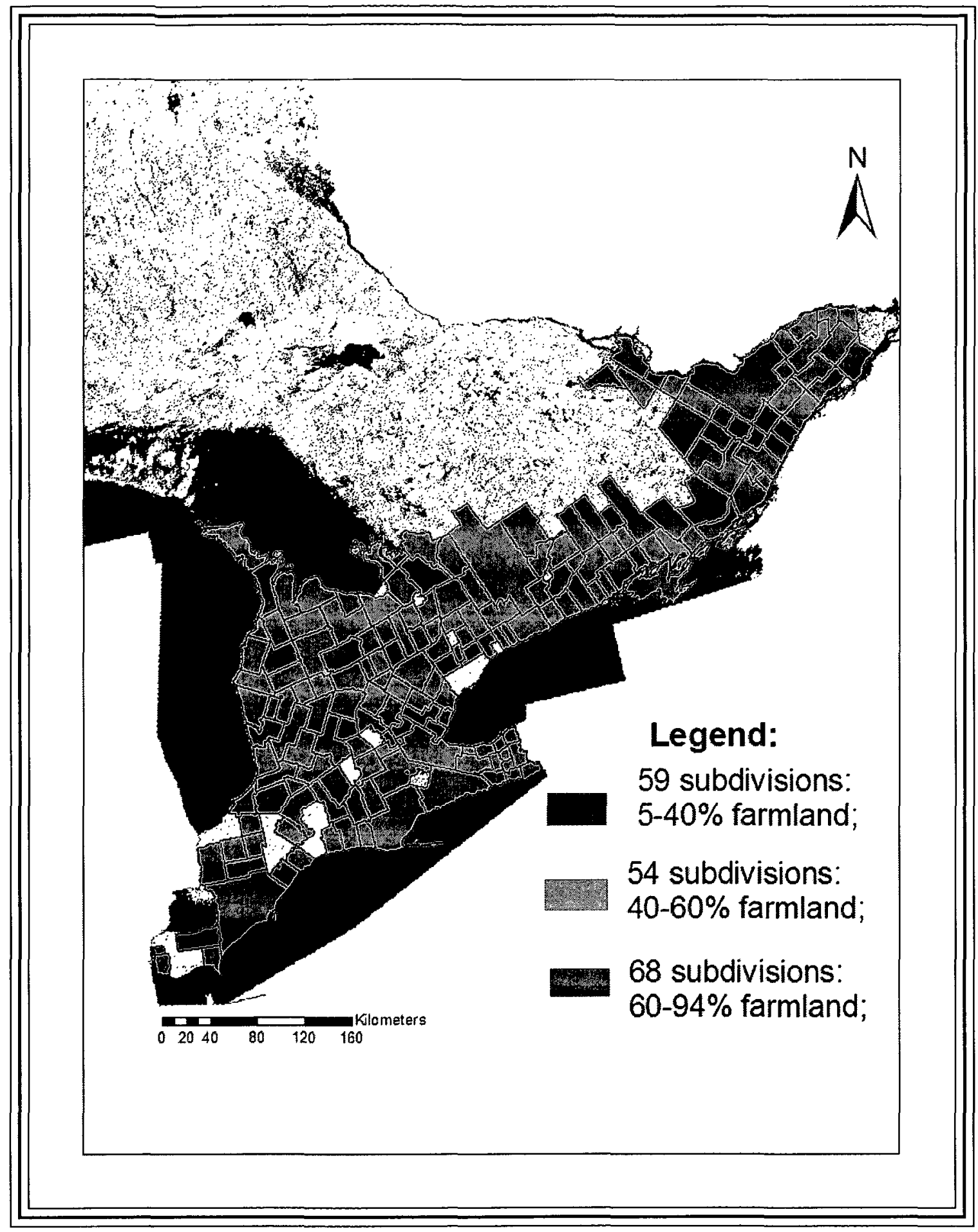

Figure 2.1 Agricultural subdivisions (subsetted by percent farmland) used in the case study for Ontario. 


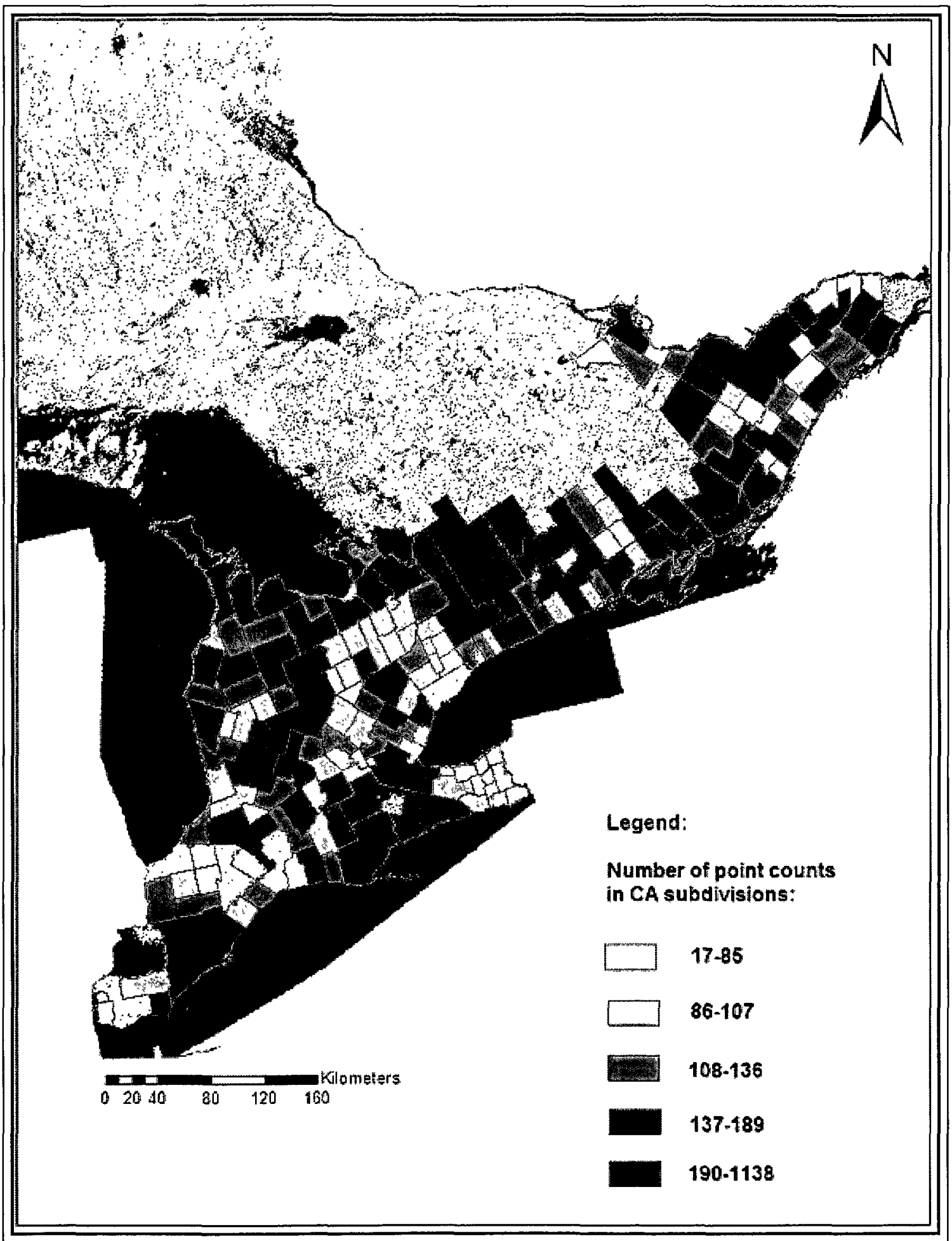

Figure 2.2 Bird point count density for agricultural subdivisions used in the case study for Ontario. 


\section{Chapter 3: Ontario Case Study Results}

\subsection{Farmland characteristics}

The 181 subdivisions included in the analysis represented $84 \%$ of farmland in Ontario. On average, farmland occupied $53 \%$ of each subdivision (Table 3.1). Crop was the most extensive cover type accounting for, on average, $38 \%$ of each subdivision. Native remnants were next at $6.3 \%$ on average, with a high of $14 \%$. Configuration within farmland showed an average farm size of 92 ha with an average of 71 ha of crop per farm. Crop heterogeneity was higher on average than farmland heterogeneity. Agricultural practices within subdivisions included, on average, a grazing intensity of 11.1 animals per hectare of pasture, $66 \%$ and $56 \%$ of crop and seeded pasture treated with pesticides and fertilizers, respectively, and 3.4 units of machinery per farm. While significant correlations existed among explanatory variables, most had low values (Pearson correlation $<0.500$; Appendix, Table A1). Exceptions were between the configuration metrics (negative), between farmland heterogeneity and row crop $\left(^{+}\right)$, native remnants (-) and average crop size $(+)$ and between pesticide use and fertilizer use (-).

Subsetting subdivisions based on percent farmland (Table 3.2) was used to examine effects of agricultural expansion and intensification on farmland birds. Percent farmland per subdivision expanded from a mean of $28 \%$ in the least intensive subset (5$40 \%$ farmland) to $76 \%$ in the most intensive subset (60-94\% farmland). Crop increased from an average of $16 \%$ to $61 \%$ reflecting a simplification in production consistent with intensification effects. Pasture remained about the same across subsets, on average, 
although the proportion of natural (versus seeded pasture) declined from 0.7 to 0.5 from the least to the most intensive subset. Averages for summer fallow, farmstead and native remnants were similar across subsets. Farmland heterogeneity decreased between the least and most intensive subsets whereas crop heterogeneity remained the same. Mean average farm size was similar across subsets whereas mean average crop per farm increased from 57 to 87 ha, the latter consistent with intensification. The average for agricultural practices (except for machinery per farm) increased from the least to the most intensive subset.

\subsection{List of farmland birds for Ontario}

A total of 159 species have been observed in agricultural landscapes based on the review of studies in five provinces in Canada and 18 states in the USA (Appendix Table A2). Of these, 79 breeding species were categorized in the current study as farmland specialists (43 species including 5 introduced) or farmland generalists (36 species) (Appendix Table A3). The remaining 80 species were categorized as "other" and excluded from further consideration because they occurred in non-breeding seasons or during the breeding season were primarily associated with more extensive areas of native habitat within agricultural landscapes rather than native remnants in farmland.

Of the 79 species of specialists or generalists, 66 breed in Ontario (Appendix Table A4). Four of these species were not detected in the subdivisions used for the case study (which represented $84 \%$ of the agricultural area in the Census of Agriculture for Ontario) and were thus removed from the candidate list. Eight species of farmland specialists ( 3 row crop and 5 pasture specialists based on the literature review) did not 
have sufficient point count data for analysis but were retained in the candidate list because they are considered species of conservation concern.

Regression models for the 54 species with sufficient point count data (Table 3.3) generally supported categorizations from the literature; specialists showed significant positive correlations with crop, pasture or farmstead, and generalists showed no correlations with cover types or significant positive correlation with a variety of cover types (including native remnants). However, two species originally categorized as generalists (Northern Mockingbird and Common Grackle) were re-categorized as specialists based on models with high explained variance and positive correlations with farmstead. Three species (Mallard, Turkey Vulture, Red-tailed Hawk) with insignificant or low variance explained $(<3 \%)$ were removed from the final list (Table 3.3). Despite low variance explained, Blue-winged Teal and Baltimore Oriole were retained for analysis and Eastern Wood-pewee excluded based on the literature and expert opinion.

Model results (coupled with expert opinion) indicated that three species had positive association with row crop (RCS, Table 3.3) and eleven species with pastures (PSS, Table 3.3). Twelve species were categorized as farmstead specialists (FSS, Table 3.3), including the Brown-headed Cowbird (despite its historical association with grasslands). Twelve generalist species were further categorized as "edge farmland generalists" (EFG, Table 3.3) based on the literature, expert opinion, and models with reasonable variance explained and significant positive correlations with farmland heterogeneity and remnants of native habitats.

The list of farmland birds for Ontario used for analysis with the 181 subdivision dataset included 54 species overall comprised of 23 farmland generalists and 34 
farmland specialists (Table 3.4). Twenty-one species were also BCR 13 priority species (18 had sufficient data for analysis). In relation to life history, 13 species are resident, 32 are short-distance migrants, 14 are long-distance migrants and 23 are ground nesters (Appendix Table A4). Farmland specialists were comprised mostly of species that historically inhabited grasslands (Appendix Table A3) as well as 5 species introduced by European settlers (and currently categorized in the EU as farmland birds; EBCC 2009). Farmland generalists were composed of species associated historically with woods, grasslands, shrub, wetlands and their edges (Appendix Table A3). Of species that were categorized by habitat association, 6 were row crop specialists (RCS), 16 pasture specialists (PSS), 12 farmstead specialists (FSS) and 11 edge farmland generalists (EFG). Of the 18 BCR 13 priority species with sufficient data for analysis, over half were pasture specialists. The final proposed list of farmland birds for Ontario was culled to only include the 45 species comprised of all 34 farmland specialists and the 11 edge farmland generalists (bolded in Table 3.4).

\subsection{Bird characteristics}

Mean abundance for all farmland birds in the 181 subdivision dataset was 12.0 birds per point per subdivision; mean richness was 5.6 species per point per subdivision (Table 3.5). On average, generalists had higher abundance and more species per point than specialists. BCR 13 priority species were relatively uncommon both in abundance and richness per point. For subdivision subsets, abundance of birds in all groups increased across the gradient of increasing percent farmland (Table 3.6). Distributional data for individual species are provided in the Appendix (Table A4). 


\subsection{Effects of farmland structure and agricultural practices}

Results of regression models for abundance and richness in the 181 subdivisions were summarized by model fit ( $p \leq 0.05 ; \triangle \mathrm{AICc}$, variance explained) and strength metrics (proportional partial regression coefficient or PPRC) to characterize relationships between farmland birds and farmland structure and agricultural practices.

Base models (i.e., regression models with the lowest $\mathrm{AICc}$ ) for abundance and richness of all farmland birds explained $28 \%$ and $14 \%$ of variation, respectively, and showed correlations with farmland structure but not practices (Table 3.7A). The numerical response (PPRC) to composition was a gain of 8.3 birds from an increase of natural pasture (from 0.1 to $16.5 \%$ ) and 3.7 birds from an increase of farmstead (from 0.1 to $11.5 \%$ ) and 1.8 species per point as crop area increased (from 1.2 to $84.2 \%$ ). Configuration resulted in a decrease of 5.1 birds per point in response to an increase in average farm size (from 18 to $194 \mathrm{ha}$ ). Increasing heterogeneity of farmland resulted in a decrease of 10.4 birds per point. Models partitioned by composition, heterogeneity, configuration or practices for abundance had AICc values well above the base model ( $\triangle \mathrm{AICc}>2$ or 4 , the cut-offs recommended by Anderson and Burnham 2002). For richness, the base model was the same as the best-fit model for composition. All other partitioned models had AICc values well above the base model.

There were two competing best-fit models for the abundance of farmland specialists (Table 3.7B), one based on practices (the lowest AICc) and the other on landscape structure $(\triangle \mathrm{AIC}=3.4)$. The latter was used as the base model because it explained twice as much variation as the former. With that, the base models for farmland specialist abundance and richness explained $50 \%$ and $47 \%$ of variation, 
respectively, and showed correlations only with farmland structure (Table 3.7B). Birds and species increased in response to composition (crop, natural and seeded pasture for both metrics; abundance also with farmstead) and decreased with configuration (average crop size for abundance; average farm size for richness) and heterogeneity (crop for abundance, farmland for both). Other than the result noted above, all other partitioned models had AICc values well above the base model.

Base models for farmland generalist abundance and richness explained a low amount of variation (9\% and $6 \%$, respectively) and showed correlations with farmland structure but not practices (Table 3.7C). For abundance, the numerical response to composition was a gain of birds per point as natural pasture increased, and a decrease with configuration (average farm size) and heterogeneity (farmland). For richness, the base model was the same as the best-fit model for composition and the numerical response to composition was a gain of species per point as native remnants and summer fallow increased. Partitioned models (other than composition) had AICc values well above the base model for abundance.

There were two competing best-fit models for the abundance of BCR 13 priority species (Table 3.7D), one based on composition and the other on composition and heterogeneity. The latter was used as the base model because it had the lower AICc. With that, the base models for BCR 13 priority species abundance and richness explained $30 \%$ and $38 \%$ of variation, respectively. Species richness showed correlations with both farmland structure and practices. Abundance and richness increased with composition (both metrics with seeded and natural pasture, richness with crop) and decreased with heterogeneity (farmland). Richness also decreased with configuration 
(farm size) and practices (grazing intensity). Partitioned models (other than composition) had $\triangle \mathrm{AICc}$ values more than 4 above the base model.

The variation explained by base models for abundance (Fig 3.1) was highest for specialists (50\%) and lowest for generalists (9\%). Except for BCR 13 priority species, response patterns to composition, configuration, heterogeneity and practices were similar across groups although explanatory variables and strengths of the numerical response varied. BCR 13 priority species had no correlation with configuration and the effect of heterogeneity was absent from a competing best-fit model. For other groups, composition and heterogeneity had numerical effects that were in opposite directions, positive and negative, respectively. Heterogeneity had the strongest numerical response of all explanatory variables with negative effects on all categories of farmland birds and especially specialists. Agricultural practices had no effect on farmland bird abundance.

The variation explained by base models for richness (Fig 3.1) was also highest for specialists (47\%) and lowest for generalists (6\%). Composition was the most important for all categories of farmland birds. It was the only set of explanatory variables significant for all birds and for generalists. Both specialists and BCR 13 priority species responded negatively to configuration and heterogeneity. Composition and heterogeneity had the strongest and equal numerical effects among variables with a positive effect of row crop on all farmland birds and a negative effect of heterogeneity on specialists. Practices were important for $\mathrm{BCR} 13$ priority species having a negative effect on richness.

The abundance of row crop specialists was positively correlated with crop area within subdivisions (Fig. 3.2; Appendix Table A5A). Visual inspection indicated that 
subdivisions with more than $40 \%$ crop supported a higher than average abundance of these species. A similar pattern was observed for pasture specialists, with higher than average abundances for subdivisions with more than $8-10 \%$ of pasture (Fig. 3.3).

\subsection{Effects of agricultural expansion and intensification}

After removal of outlier species, the abundance of the remaining 41 species of farmland birds were analyzed (bolded species in Table 3.4); richness was not because it was highly correlated with abundance overall (Fig.3.4) and especially for specialists (Pearson correlation $=0.79)$ and BCR 13 priority species $(0.81)$. Regression analyses were conducted with the three subdivision subsets with differing percent farmland and intensification (Appendix Table A5B,C,D). Regression results for the 181 subdivision dataset were also tabulated for comparative purposes (Appendix Table A5A). Base models (i.e., the most parsimonious regression models with the lowest AICc) were used for comparisons.

In the least intensive subset (5-40\% farmland), the base model for edge farmland generalists (Table $3.8 \mathrm{~A}$ ) explained $34 \%$ of variation in abundance with increases in response to composition (native remnants) and configuration (more edge from smaller farm size and larger crop size per farm) and a decrease with practices (fertilizer input). In the moderate subset $(40-60 \%$ farmland), only practices were significant with a negative effect on abundance related to pesticide inputs. In the most intensive subset (60-94\% farmland), abundance increased in response to composition (natural pasture) and decreased with practices (grazing intensity). There was no observed effect of heterogeneity in any subset. Compared to the full dataset (181 subdivisions), subsetting 
showed the importance of native remnants within farmland in the least intensive subset and natural pasture in the most intensive subset, and the important, and negative effects of practices that were not otherwise evident.

For BCR 13 priority species (Table 3.8A), the base models explained $13 \%$ of variation in abundance in the least intensive subset, $25 \%$ in the moderate and $50 \%$ in the most intensive. Only composition was significant, with a positive effect on abundance related to natural pasture (least intensive subset), seeded pasture (moderate subset) and both pastures plus crop (most intensive subset). The strength of response (PPRC) increased gradually from the least to the most intensive subset. There was no observed effect on abundance of configuration, heterogeneity or practices in any subset. Subset results showed no effects of heterogeneity in contrast to the full dataset.

For farmland specialists, the base model for the least intensive subset (Table 3.8A) explained $56 \%$ of variation in abundance with an increase in response to composition (crop) and decreases with configuration (crop size) and heterogeneity (farmland). In the moderate subset (11\% variance explained), only configuration was important, with a negative effect from farm size. In the most intensive subset $(20 \%$ variance explained), abundance decreased in response to composition (native remnants) and heterogeneity (crop). There was no observed effect of practices in any subset or the full dataset. Subsetting showed that composition was not as important as it was in the full dataset and that its effect varied among cover types across subsets. Effects of configuration and heterogeneity also varied across subsets, a result not evident in the full dataset. 
Regression analyses for species grouped by habitat association (Appendix Table A5) helped to explain the variability within farmland specialists. The base model for row crop specialists in the least intensive subset (Table $3.8 \mathrm{~B}$ ) explained $56 \%$ of variation in abundance, with a response only to composition (positive to crop and summer fallow and negative to native remnants). In the moderate subset, abundance decreased in response to composition (native remnants) and increased in response to practices (grazing intensity). In the most intensive subset, abundance increased in response to composition (crop). There was no observed effect of configuration in any subset. Subsetting showed that composition was the most important factor for row crop specialists. A negative response to heterogeneity (crop) was detected only in the full dataset.

The base models for pasture specialists explained $22 \%$ to $55 \%$ of variance (Table 3.8B). In the least intensive subset, composition (crop and natural pasture) had a positive effect and practices (fertilizer inputs) had a negative effect. In the other subsets, only composition was significant with a positive response to seeded pasture in the moderate subset and both pastures and crop in the most intensive subset. In contrast to the full dataset, native remnants were not significant. Configuration and heterogeneity had no effects in any subset or the full dataset.

For farmstead specialists (Table $3.8 \mathrm{~B}$ ), base models explained $21 \%$ to $59 \%$ of variance. In the least intensive subset, composition (farmstead) had a positive effect and configuration (average crop size) and heterogeneity (farmland) had strong negative effects. In the moderate subset, composition (seeded pasture) and configuration (crop size) had negative effects. In the most intensive subset, configuration (crop size) had a 
negative effect and practices showed a positive effect of pesticide use and negative effect of fertilizer use. Subsetting showed similarities between the least intensive and full datasets.

Farmland specialists categorized by habitat association and BCR 13 priority species (Table 3.8) responded most often across subsets to landscape structure (composition, configuration and heterogeneity) compared to practices. Mostly positive responses to composition were evident in the least and most intensive subsets. Heterogeneity and configuration were generally less important across subsets for BCR 13 priority species and farmland specialists except farmstead specialists in all subsets and edge farmland generalists in the least intensive subset. When detected, effects of practices were negative for edge farmland generalists and pasture specialists, positive for row crop specialists and mixed for farmstead specialists.

To further explore responses in relation to landscape structure, farmland birds were graphed against percent row crop per subdivision (Fig.3.5) because it was the most extensive cover type and was significant in many base models, especially for specialists. When responses were combined (Fig. 3.6), it was evident that there were tradeoffs in abundance of species across the gradient in landscape composition. The abundance of farmland birds was optimized when crop occupied between $40-70 \%$ of subdivisions. 
Table 3.1 Descriptive statistics for explanatory variables across 181 subdivisions in Ontario.

\begin{tabular}{|c|c|c|c|c|}
\hline \multirow{2}{*}{\multicolumn{2}{|c|}{\begin{tabular}{l|l} 
Explanatory variables & Code
\end{tabular}}} & \multicolumn{3}{|c|}{ 181subdivisions } \\
\hline & & Mean & SD & Range \\
\hline Subdivision area (ha) & & 48,214 & 42,160 & $000-347.000$ \\
\hline $\begin{array}{l}\text { Farmland ( } \% \text { subdivision } \\
\text { area) }\end{array}$ & & & 22.0 & $5 \cdot 0 \cdot 94.0$ \\
\hline \multicolumn{5}{|c|}{$\begin{array}{l}\text { Composition (\% subdivision } \\
\text { area) }\end{array}$} \\
\hline $\mathrm{R} \theta W$ crop & GOP & 378 & 215 & 1.2 .84 .2 \\
\hline Summer fallow & SFALP & 0.14 & 0.20 & $0-1.28$ \\
\hline Tame'seeded pasture & TSPP & 2.8 & 2.3 & $0.1-2.3$ \\
\hline Natural pasture & NPP & 3.4 & 2.6 & $0.1-16.5$ \\
\hline $\begin{array}{l}\text { Native remnants } \\
\text { trees, woods, wetlands in } \\
\text { farmland) }\end{array}$ & $T W W P$ & & 2.9 & $0.2-1.4 .4$ \\
\hline Farmstead (includes road) & FSAP & 2.2 & 1.1 & $0.1-11.5$ \\
\hline \multicolumn{5}{|c|}{ Heterogeneity } \\
\hline Farmland & SWDIER & 0.97 & $0=0$ & $0.24-1.51$ \\
\hline Crop & SWDICR & 1.40 & 0.30 & $0.20-2.07$ \\
\hline \multicolumn{5}{|l|}{ Configuration } \\
\hline Average farm size (ha) & AVES & 92.4 & 26.2 & $8.0-194.0$ \\
\hline Average crop per farm (ha) & AVCRS & 70.6 & 24.0 & $16.0-152.0$ \\
\hline \multicolumn{5}{|c|}{ Agricultural Practices } \\
\hline \multicolumn{5}{|c|}{$\begin{array}{l}\text { Wvestock grazing } \\
\text { (headhina natural pasture) }\end{array}$} \\
\hline Fertilizer input $(\%)$ & FERTIN & 55.9 & 19.8 & $0.0-94.6$ \\
\hline Pesticide input $(\%)$ & PESTN & 66.2 & 38.5 & $21.0-296.0$ \\
\hline Machinery per farm (no.) & AMPF & 3.4 & 0.4 & $2.4-4.8$ \\
\hline
\end{tabular}

Explanatory note: Pesticide input and fertilizer input calculated as summed area treated divided by total area of crop and seeded pasture per subdivision 
Table 3.2 Descriptive statistics for explanatory variables for subdivision subsets in Ontario.

\begin{tabular}{|c|c|c|c|c|c|c|c|c|c|c|}
\hline \multirow{2}{*}{\multicolumn{2}{|c|}{ Explanatory variables code }} & \multicolumn{3}{|c|}{59 subdivisions } & \multicolumn{3}{|c|}{54 subdivisions } & \multicolumn{3}{|c|}{68 subdivisions } \\
\hline & & Mean & SD & Range & Mean & SD & Range & $\begin{array}{c}\text { Mea } \\
\mathbf{n}\end{array}$ & SD & Range \\
\hline \multicolumn{2}{|c|}{ Farmland (\% subdrivision area) } & 28.0 & 10.0 & & 50.0 & 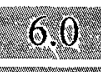 & & 76.0 & 10.0 & \\
\hline \multicolumn{2}{|c|}{ Composition ( $\%$ subdivision area) } & & & & & & & & & \\
\hline \multicolumn{2}{|c|}{ Row crop $\quad$ CROP } & 16.0 & 7.5 & $1.2-37.0$ & 32.6 & 8.1 & $16.0-47: 0$ & 61.0 & 11.7 & 34.0 \\
\hline \multirow{2}{*}{$\begin{array}{l}\text { Summer fallow } \\
\text { Tame/seeded pasture }\end{array}$} & SFALP & 0.14 & 0.20 & $0-1$. & 0.16 & 0.17 & $0-1.00$ & 0.10 & 0.19 & \\
\hline & TSPP & 1.9 & 1,3 & $0.1-6.5$ & 3.6 & 20 & $0.3-9.6$ & 3.0 & 2.9 & 0.3 \\
\hline \multirow{2}{*}{ Natural pasture } & NPP & 3.7 & 2.9 & 0.1 & 4.4 & 2.5 & $1.2-12.8$ & 2.5 & 2.2 & 0.2 \\
\hline & TWWP & 5.2 & 3.1 & $0.2-13.1$ & 7.0 & 2.4 & $1.9-13.7$ & 6.8 & 2.7 & $1.6-14.4$ \\
\hline \multirow{2}{*}{\multicolumn{2}{|c|}{$\begin{array}{l}\text { Farmstead } \\
\text { Treterogeneity }\end{array}$}} & 1.5 & 0.8 & & 2.4 & 1.0 & $11-62$ & 2.6 & 1.2 & 1.0 \\
\hline & & & 20 & & & & & & \\
\hline \multirow{2}{*}{\multicolumn{2}{|c|}{$\begin{array}{l}\text { Farmland } \\
\text { Crop }\end{array}$}} & 1.20 & 0.30 & $0.40-7.51$ & 1.10 & 0.20 & $0.60=1.46$ & 0.73 & \multicolumn{2}{|c|}{$0.20-0.20=1.30$} \\
\hline & & 1.40 & 0.30 & & 1.60 & 0.30 & $0.60-2.10$ & 1.50 & 0.25 & 0.7 \\
\hline \multicolumn{11}{|c|}{ Configuration } \\
\hline \multicolumn{2}{|c|}{ Average farm size (ha) V AVFS } & 890 & 30.1 & $18.0-194.0$ & 89.7 & 23.7 & $22.0-162.0$ & 98.5 & \multicolumn{2}{|c|}{$24.0 \times 24.0-161.0$} \\
\hline Average crop per farm (ha) & AVCRS & 56.8 & 20.5 & $16.0-$ & 65.6 & 18.8 & $19.0-113.0$ & 87.0 & 21.1 & 19.0 \\
\hline \multicolumn{11}{|l|}{ Agricultural Practices } \\
\hline \multicolumn{2}{|l|}{$\begin{array}{l}\text { Livestock grazing } \\
\text { (head/ha natural pasture) }\end{array}$} & & & & 7.2 & 4.4 & $1.0-25.0$ & 20.2 & \multicolumn{2}{|c|}{$139=2.0-58.5$} \\
\hline \multirow{2}{*}{$\begin{array}{l}\text { Fertilizer input }(\%) \\
\text { Pestielde input }(\%)\end{array}$} & FERTIN & 43.8 & 19.6 & $0.01-87.6$ & 52.1 & 16.0 & $20.0-81.0$ & 69.6 & \multirow{2}{*}{\multicolumn{2}{|c|}{\begin{tabular}{r|r}
13.8 & $11.5-94.6$ \\
27.5 & $16.0-173.0$
\end{tabular}}} \\
\hline & PESTIN & 44.0 & 34.9 & $0.1-213.0$ & 59.0 & 36.0 & $7.0-205.0$ & 91.8 & & \\
\hline Machinery per farm & AMPF & 3.1 & 0.4 & $2.4-4.8$ & 3.3 & 0.3 & $2.8-4.5$ & 3.7 & 0.3 & $3.0-4.5$ \\
\hline
\end{tabular}


Table 3.3 Regression results for candidate farmland bird species in 181 subdivisions in Ontario. Explanatory notes below.

\begin{tabular}{|c|c|c|c|c|}
\hline Species code & Regression model & Category & aR2 (\%) & $\boldsymbol{P}$ \\
\hline 1.RIPH & $0.003-0.00$ TWWP & FG [RCS] & 4.3 & 0.003 \\
\hline 2.WITU & $-0.007-0.00 \mathrm{CTPHA}+0.00$ FERTIN +0.8 NPP & FG & 5.7 & 0.004 \\
\hline 3. CAGO & $0.67-0.9$ AVFS & FG & 8.2 & 0.000 \\
\hline 4. MALL* & No significant model & $\mathrm{FG}[\mathrm{O}]$ & 1.3 & 0.118 \\
\hline 5. BWTE & $-0.005-0.00 \mathrm{CROP}+0.00 \mathrm{NPP}+0.002 \mathrm{AMPF}$ & $\mathrm{FG}$ & 2.6 & 0.026 \\
\hline 6. TUVU* & No significant model & $\mathrm{FG}[\mathrm{O}]$ & 0.1 & 0.350 \\
\hline 7. AMKE & $0.002+0.2$ TSPP & FS [PSS] & 9.3 & 0.000 \\
\hline 8. NOHA & $0.002+0.05$ CTPHA & FS [PSS] & 6.5 & 0.000 \\
\hline 9. RTHA & $0.018-0.0001$ AVFS & FG [O] & 2.3 & 0.024 \\
\hline 10. KILL & $0.121+0.3$ CROP - 0.1 TWWP -0.1 SWDICR & $\mathrm{FS}[\mathrm{RCS}]$ & 47.5 & 0.000 \\
\hline 11. UPSA & $0.000+0.1 \mathrm{NPP}$ & FS [PSS] & 11.1 & 0.000 \\
\hline 12. RBGU & $0.067+0.8$ SFALP & $\mathrm{FG}$ & 6.1 & 0.000 \\
\hline 13. RODO & $0.56+0.3$ CTPHA -0.3 SWDIFR -0.3 FERTIN & FS [FSS] & 16.6 & 0.000 \\
\hline 14. MODO & $1.6-1.1$ SWDIFR -0.5 CTPHA -0.5 AVCRS +0.3 NPP & FS [FSS] & 37.7 & 0.000 \\
\hline 15. CONI & $0.00+0.05 \mathrm{NPP}-0.04 \mathrm{TWWP}$ & $\mathrm{FS}[\mathrm{PSS}]$ & 8.0 & 0.000 \\
\hline 16. RHWO & $0.014+0.003$ SFALP -0.1AVCRS - 0.01 FERTIN -0.01 SWDIFR & $\mathrm{FG}[\mathrm{EFG}]$ & 3.8 & 0.038 \\
\hline 17. NOFL & $0.08-0.1$ CROP & $\mathrm{FG}$ & 14.6 & 0.000 \\
\hline 18. EAPH & $\begin{array}{l}-0.007+0.1 \text { SWDIFR }+0.1 \text { TWWP }-0.05 \text { FSAP }-0.03 \text { TSPP }-0.03 \\
\text { SWDICR }+0.01 \text { AVFS }\end{array}$ & $\mathrm{FG}[\mathrm{EFG}]$ & 40.3 & 0.000 \\
\hline 19. EAWP* & $0.11-0.001$ AVCRS & $\mathrm{FG}[\mathrm{O}]$ & 4.6 & 0.002 \\
\hline 20. EAKI & $0.128+0.2$ NPP -0.3 PESTIN +0.1 CROP -0.1 AVFS & FG [EFG] & 29.6 & 0.000 \\
\hline 21. GCFL & $0.073+0.1$ SWDIFR - 0.07 SWDICR -0.1 FSAP & FG [EFG] & 30.4 & 0.000 \\
\hline 22. BLJA & $0.54-0.2$ CROP -0.2 AMPF +0.1 FERTIN - 0.1 SWDICR & FG & 24.5 & 0.000 \\
\hline 23. AMCR & $-0.22+0.5$ SWDIFR +0.3 FERTIN -0.3 FSAP -0.4 AVFS +0.4 AVCRS & FG & 16.2 & 0.000 \\
\hline 24. CEDW & $0.31-0.1$ AVCRS +0.1 SFALP & $\mathrm{FG}$ & 4.5 & 0.006 \\
\hline 25. TRES & $0.21+0.3 \mathrm{NPP}$ & FS [FSS] & 5.0 & 0.001 \\
\hline
\end{tabular}




\begin{tabular}{|c|c|c|c|c|}
\hline Species code & Regression model & Category & aR2 (\%) & $\boldsymbol{P}$ \\
\hline 26. BARS & $0.77+0.2$ CROP -0.3 AVFS +0.6 NPP -0.7 SWDIFR & FS [FSS] & 22.8 & 0.000 \\
\hline 27. CLSW & $-0.016+0.2$ CROP & FS [FSS] & 10.1 & 0.000 \\
\hline 28. HOLA & $0.1+0.7$ CROP -0.2 SFALP -0.2 FSAP -0.2 SWDICR -0.1 TWWP & FS [RCS] & 58.6 & 0.000 \\
\hline 29. HOWR & $0.06+0.1$ CROP -0.1 CTPHA +0.1 NPP & FS [FSS] & 6.8 & 0.001 \\
\hline 30. NOMO & $\begin{array}{l}0.03-0.00 \text { AVFS }+0.008 \text { FSAP }-0.001 \text { TWWP }-0.009 \text { SWDICR }+0.015 \\
\text { SFALP }-0.001 \text { CROP }\end{array}$ & FG $[\mathrm{FSS}]$ & 47.0 & 0.000 \\
\hline 31. BRTH & $0.004+0.1 \mathrm{NPP}$ & FG [EFG] & 33.0 & 0.000 \\
\hline 32. EUST & 5.1 -3.4 SWDIFR -2.2 AVCRS +2.1 FSAP -1.0 CTPHA & FS [FSS] & 34.5 & 0.000 \\
\hline 33. EABL & $0.009+0.1$ TSPP & $\mathrm{FG}[\mathrm{EFG}]$ & 7.5 & 0.000 \\
\hline 34. AMRO & $1.6-0.4$ AVFS -0.6 SWDIFR -0.4 CTPHA +0.5 NPP & $\mathrm{FG}$ & 12.0 & 0.000 \\
\hline 35. HOSP & $\begin{array}{l}\text { 4.5-3.4 SWDIFR -0.8 AVCRS - 1.4 CROP -0.8 SWDICR + 0.9 FSAP } \\
+0.8 \text { TSPP }\end{array}$ & FS [FSS] & 51.1 & 0.000 \\
\hline 36. AMGO & $0.545+0.4$ TSPP + 0.2 SFALP & FG & 5.9 & 0.002 \\
\hline 37. HOFI & $\begin{array}{l}0.67+0.03 \text { TWWP }-0.2 \text { AVFS }+0.3 \text { PESTIN }-0.5 \text { CROP }-0.5 \\
\text { SWDIFR }+0.1 \text { NPP }+0.2 \text { TSPP-0.1 SWDICR }\end{array}$ & FS [FSS] & 45.9 & 0.000 \\
\hline 38. COYE & $-0.18+0.3$ SWDIFR +0.2 AVFS -0.3 TSPP +0.1 TWWP & FG [EFG] & 38.8 & 0.000 \\
\hline 39. BAOR & $0.109+0.2$ FSAP & FG & 2.9 & 0.013 \\
\hline 40. OROR & $0.069-0.05$ SWDIFR -0.1 CTPHA -0.01 AVCRS & FG & 7.3 & 0.001 \\
\hline 41. $\mathrm{BHCO}$ & $0.1+0.3$ CROP + 0.3 FSAP -0.2 CTPHA & FS [FSS] & 22.0 & 0.000 \\
\hline 42. RWBL & $2.26+0.9$ AVCRS +0.9 NPP -1.2 SWDIFR -1.3 FERTIN +1.0 FSAP & $\mathrm{FG}[\mathrm{EFG}]$ & 16.4 & 0.000 \\
\hline 43. COGR & $1.98-1.3$ SWDIFR + 0.9 FSAP & FG [FSS] & 30.6 & 0.000 \\
\hline 44. EAME & $0.007+0.3 \mathrm{NPP}+0.3 \mathrm{TSPP}$ & FS [PSS] & 45.6 & 0.000 \\
\hline 45. BOBO & $-0.037+1.4 \mathrm{TSPP}+0.2$ AVFS $-0.3 \mathrm{TWWP}+0.4 \mathrm{NPP}+0.2 \mathrm{CROP}$ & FS [PSS] & 43.7 & 0.000 \\
\hline 46. SOSP & $0.48+0.2 \mathrm{CROP}+0.3 \mathrm{NPP}$ & $\mathrm{FG}[\mathrm{EFG}]$ & 9.2 & 0.000 \\
\hline 47. SAVS & $0.081+0.5$ CROP + 1.1 TSPP -0.2 TWWP & FS [PSS] & 43.3 & 0.000 \\
\hline 48. GRSP & $0.000+0.03 \mathrm{NPP}$ & FS [PSS] & 12.4 & 0.000 \\
\hline 49. CHSP & $0.135+0.3$ TWWP +0.2 PESTIN & $\mathrm{FG}[\mathrm{EFG}]$ & 13.0 & 0.000 \\
\hline 50. CCSP & $0.000+0.01 \mathrm{NPP}$ & FS [PSS] & 6.8 & 0.000 \\
\hline
\end{tabular}




\begin{tabular}{|l|l|l|c|c|}
\hline Species code & \multicolumn{1}{|c|}{ Regression model } & Category & aR2 (\%) & $\boldsymbol{P}$ \\
\hline 51. FISP & $0.018+0.1 \mathrm{NPP}-0.06 \mathrm{TSPP}$ & FS [PSS] & 10.7 & 0.000 \\
\hline 52. VESP & $0.021+0.2 \mathrm{CROP}-0.1 \mathrm{CTPHA}-0.1$ SWDICR & FS [RCS] & 23.6 & 0.000 \\
\hline 53. EATO & $0.008+0.06 \mathrm{NPP}-0.06 \mathrm{TSPP}$ & FS $[\mathrm{PSS}]$ & 17.7 & 0.000 \\
\hline 54. INBU & $0.065+0.2 \mathrm{FERTIN}-0.06 \mathrm{SWDICR}$ & FG $[\mathrm{EFG}]$ & 8.5 & 0.000 \\
\hline
\end{tabular}

\section{Explanatory notes:}

Species code explained in Appendix Table A4

Best-fitted models $((p \leq 0.05$, lowest AICc) using forward regression (except when * denotes backward regression); variable coefficient as partial proportional regression coefficient (PPRC)

Explanatory variables: $\mathrm{CROP}=$ row crop percent per subdivision, $\mathrm{SFALP}=$ summer fallow percent per subdivision, NPP $=$ natural pasture percent per subdivision, TSPP = tamed and seeded pasture percent per subdivision, TWWP = trees, woods and wetlands in farmland as percent per subdivision, FSAP = farmstead area percent per subdivision; AVFS = average farm size per subdivision, AVCRS $=$ average area of crop per farm per subdivision; CTPHA = livestock per hectare per subdivision, PESTIN = pesticide input, FERTIN = fertilizer input; AMPF = machinery per farm per subdivision, SWDIF = farmland diversity index; SWDICR = crop diversity index.

Category: FS = farmland specialist; RCS $=$ row crop specialist, PSS $=$ pasture specialist, FSS $=$ farmstead specialist, FG $=$ farmland generalist, $\mathrm{EFG}=$ edge farmland generalist, $\mathrm{O}=$ other, $[$ ] = additional category

$\mathrm{aR}^{2}(\%)=$ percent variance explained 
Table 3.4 List of farmland birds for Ontario. Final in bold.

\begin{tabular}{|c|c|c|c|c|c|}
\hline N & Farmiand specialists & Category & N & Farmland generalists & Category \\
\hline & Northern Bobwhite* & RCS & 1 & Red-headed Woodpecker* & EFG \\
\hline 2 & Ring necked Pheasant & RCS & 2. & Eastern Phoebe & EEC \\
\hline 3 & Gray Partridge & RCS & 3 & Eastern Kingbird* & EFG \\
\hline 4. & Killdeer & RCS & 4. & Great crested flycatcher & EFC \\
\hline & Horned Lark & RCS & 5 & Brown Thrasher* & EFG \\
\hline 6 & Vesper Sparrow: & RCS & 6 & Eastern Bluebird & EFE \\
\hline 7 & American Kestrel* & PSS & 7 & Common Yellowthroat & EFG \\
\hline 8 & Northern Harrier: & PSS & 8 & Song Spariow & EFG \\
\hline 9 & Upland Sandpiper & PSS & 9 & Chipping Sparrow & EFG \\
\hline 10 & Barn Owl & PSS & 10 & IndigoBunting & EFG \\
\hline 11 & Short-eared Owl* & PSS & 11 & Red-winged Blackbird & EFG \\
\hline 12. & Common Nighthawk t & eSS & 12. & Blue-winged Teal & $\mathrm{FG}$ \\
\hline 13 & Loggerhead Shrike* & PSS & 13 & Wild Turkey & FG \\
\hline 14 & Eastern Meadowlark & PSS & 14 & Canada Goose & EO \\
\hline 15 & Bobolink* & PSS & 15 & Ring-billed Gull & FG \\
\hline 16 & Savaninah Sparrow & PSS & 16 & Northern Elicker* & $\mathrm{ESO}$ \\
\hline 17 & Grasshopper Sparrow* & PSS & 17 & Blue Jay & FG \\
\hline 18 & Henslow's Sparrow: & PSS & 18 & American Crow & E) \\
\hline 19 & Clay-colored Sparrow & PSS & 19 & Cedar Waxwing & FG \\
\hline 20 & Field Sparrow. & PSS & 20. & American Robin & $\mathrm{FG}$ \\
\hline & Eastern Towhee* & PSS & 21 & American Goldfinch & FG \\
\hline 22 & Dickcissel* & PSS & 22. & Baltimore Orioles & FG \\
\hline & Rock Pigeon & FSS & 23 & Orchard Oriole & FG \\
\hline 24. & Mourning Doye & ISS & & 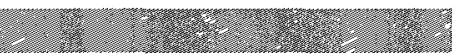 & \\
\hline 25 & Tree Swallow & FSS & & & \\
\hline 26 & Barn Swallowt & ESS & & & \\
\hline 27 & Cliff Swallow & FSS & & & \\
\hline 28 & House Wren & ESS & & & \\
\hline 29 & Northern Mockingbird & FSS & & & \\
\hline 30 & European Starling & ESS & & & \\
\hline & House Sparrow & FSS & & & \\
\hline 32 & House Finch & FSS & & & \\
\hline & Brown-headed Cowbird & FSS & & & \\
\hline 34 & Common Grackle & FSS & 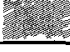 & & \\
\hline
\end{tabular}

\section{Explanatory notes:}

Species scientific names and codes in Appendix Table A4

* Priority species for BCR 13 in Ontario

Category codes: $\mathrm{RCS}=$ row crop specialists, $\mathrm{PSS}=$ pasture specialists, $\mathrm{FSS}=$ farmstead specialists, $\mathrm{EFG}=$ edge farmland generalists, $\mathrm{FG}=$ farmland generalists 
Table 3.5 Descriptive statistics for bird response variables for 181 subdivisions in Ontario. $\mathrm{n}=$ number of species included in regression analyses.

\begin{tabular}{|c|c|c|c|}
\hline Response vatiables & Mean & SD & Range \\
\hline \multicolumn{4}{|c|}{ Abundance (mean no. birds per point count per subdivision) } \\
\hline All farmiand birds $(n-53)^{*}$ & 12.0 & 4.0 & $4.1-30.18$ \\
\hline farmiand generalists $(n=23)$ & 7.0 & 1.9 & $3.2-15.2$ \\
\hline Edge farmland generalists $(n=11)$ & 2.9 & 0.8 & $1.1-6.0$ \\
\hline Farmland specialists $(\mathrm{n}=30) *$ & 5.0. & 2.5 & $0.8-17.1$ \\
\hline Row crop specialists $(n=6)$ & 0.3 & 0.4 & $0-2.1$ \\
\hline Pasture : & 1.1 & 0.6 & $0.2-3.6$ \\
\hline Farmstead specialists $(n=12)$ & 3.1 & 2.1 & $0.5-16.5$ \\
\hline BCR 13 priority species $(n=1 / 7)$ & $1,3=$ & Q6. & $0.2-4.4$ \\
\hline Richness (mean no. species per point & subdiv & 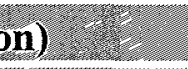 & \\
\hline All farmland birds $(n=53) *$ & 5.6 & 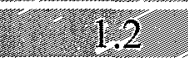 & 2.729 .8 \\
\hline Farmland generalists $(n=23)$ & 3.5 & 0.6 & $2.2-6.1$ \\
\hline Farmland specialists (n=30) & 2.0 & 0.8 & $130.5-42$ \\
\hline BCR 13 priority species $(\mathrm{n}=17)$. & 0.5 & 0.3 & 0.2 .2 .0 \\
\hline
\end{tabular}

*Four species (all BCR 13 priority species) had no observations (Barn Owl, Loggerhead Shrike, Henslow's Sparrow, Dickcissel) 
Table 3.6 Descriptive statistics for bird response variables for subdivision subsets in Ontario.

\begin{tabular}{|c|c|c|c|c|c|c|c|c|c|c|c|}
\hline \multirow{2}{*}{ Species } & \multirow[t]{2}{*}{ Variable } & \multirow[t]{2}{*}{ Code } & \multicolumn{3}{|c|}{59 subdivisions } & \multicolumn{3}{|c|}{54 subdivisions } & \multicolumn{3}{|c|}{68 subdivisions } \\
\hline & & & Mean & SD & Range & Mean & SD & Range & $\begin{array}{c}\text { Mea } \\
\text { n }\end{array}$ & SD & Range \\
\hline & $\begin{array}{l}\text { Farmlate } \\
\text { (os area per subdivisien) }\end{array}$ & & 28.0 & 100 & $5.0-39.9$ & 50. & 6.0 & $40.0-599$ & 76.0 & 10. & $60.0-94.0$ \\
\hline$x=$ & & & andanc & mean & birds pe & point co & ers $\mathrm{si}$ & ision) & 10 & 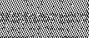 & 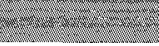 \\
\hline $15^{*} \dagger$ & BCR 13 priority species & PRS & 0.6 & 0.3 & $0-1.9$ & 1.0 & 0.6 & $0.3-3.3$ & 1.1 & 0.7 & $0.1-3.6$ \\
\hline 111 & Edge farmland generalists & EEFG & 2.7.7. & 0.9 & $1.1-4.7$ & 2.8 & 0.7 & 1.4-4.5 & 3.1 & 0.9 & $2.0-6.0$ \\
\hline $30^{*}$ & Farmland specialists & FS & 4.9 & 3.1 & $1-19$ & 5.3 & 2.5 & $2-19.5$ & 7.9 & 2.4 & $4.0-15.0$ \\
\hline 6. & Row crop specialists & $\mathrm{R} C \mathrm{~S}$ & 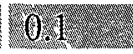 & 0,08 & 0.0 .4 & 0.2 & 0.08 & $0.03=0.5$ & 0.6 & 0.4 & $0.05-2.1$ \\
\hline $12 *$ & Pasture specialists & PSS & 0.5 & 0.3 & $0.03-1.8$ & 0.9 & 0.5 & $0.3-3.2$ & 1.0 & 0.6 & $0.05-3.4$ \\
\hline 12. & Harmstead specialists & HSS & 4.3 & 30 & $0.8-19.1$ & 4.2 & 2.4 & $1.3-18.2$ & 604 & 2.0 & $3.2-12.5$ \\
\hline
\end{tabular}

* BAOW, LOSH, HESP and DICK had no OBBA point count observations

$†$ NOFL and BAOR not included because categorized as farmland generalists 
Table 3.7 Regression results for bird abundance and richness in 181 subdivisions in Ontario for A. All farmland birds B. Farmland specialists C. Farmland generalists and D. BCR 13 priority species. Only best-fit models $(p \leq 0.05$, lowest AICc) tabulated. Base model generally had the lowest AICc. PPRC = partial proportional regression coefficient (no. birds or species per point per subdivision); sum bolded.

A. All farmland birds (No. species $=53$ )

\begin{tabular}{|c|c|c|c|c|c|c|c|c|}
\hline \multirow{3}{*}{$\begin{array}{l}\text { Response Variables: } \\
\text { Overall farmland birds }\end{array}$} & \multicolumn{4}{|c|}{ Abundance } & \multicolumn{4}{|c|}{ Richness } \\
\hline & \multicolumn{3}{|c|}{ Partitioned models } & \multirow{2}{*}{$\begin{array}{c}\text { Base model: } \\
\mathrm{aR}^{2}(\%)=28 \\
\mathrm{AICc}=\mathbf{9 6 8} \\
\text { Intercept }=\mathbf{2 0 . 8}\end{array}$} & \multicolumn{3}{|c|}{ Partitioned models } & \multirow{2}{*}{$\begin{array}{c}\text { Base model } \\
\mathrm{aR}^{2}(\%)=14 \\
\mathrm{AICc}=562.1 \\
\text { Intercept }=5.3\end{array}$} \\
\hline & & & & & & & & \\
\hline Model statistics & PPRC & $a R^{2}(\%)$ & $\triangle \mathrm{AICc}$ & PPRC & PPRC & $a R^{2}(\%)$ & $\triangle \mathrm{AICc}$ & PPRC \\
\hline Composition & & 18 & 20.1 & & & 14 & 0 & \\
\hline Crop \% & 5.0 & & & & 1.8 & & & 1.8 \\
\hline Seeded pasture $\%$ & & & & & & & & \\
\hline Natural pasture $\%$ & & & & 8.3 & & & & \\
\hline Native remnants $\%$ & -3.6 & & & & & & & \\
\hline Farmstead \% & 5.9 & & & 3.7 & & & & \\
\hline Summer fallow $\%$ & & & & & & & & \\
\hline Configuration & & 15 & 25.2 & & & 9 & $\mathbf{1 3 . 5}$ & \\
\hline Average farm size & -8.6 & & & -5.1 & -2.1 & & & \\
\hline Average crop size & 9.5 & & & & 2.2 & & & \\
\hline Heterogeneity & & 19 & 15.1 & & & 10 & 10 & \\
\hline Farm & -7.1 & & & -10.4 & -1.6 & & & \\
\hline Crops & & & & & & & & \\
\hline Practices & & 9 & 33.8 & & & 9 & 12.0 & \\
\hline Livestock per hectare & & & & & & & & \\
\hline Average machinery & & & & & & & & \\
\hline Fertilizer input & 5.6 & & & & & & & \\
\hline Pesticide input & & & & & 1.6 & & & \\
\hline
\end{tabular}


Table 3.7 Regression results for bird abundance and richness in 181 subdivisions in Ontario for A. All farmland birds B. Farmland specialists C. Farmland generalists and D. BCR 13 priority species. Only best-fit models ( $p \leq 0.05$, lowest AICc) tabulated. Base model generally had the lowest AICc. PPRC = partial proportional regression coefficient (no. birds or species per point per subdivision); sum bolded.

B. Farmland Specialists (No. species $=30$ )

\begin{tabular}{|c|c|c|c|c|c|c|c|c|}
\hline \multirow{3}{*}{$\begin{array}{l}\text { Response Variables: } \\
\text { Farmland Specialists }\end{array}$} & \multicolumn{4}{|c|}{ Abundance } & \multicolumn{4}{|c|}{$\begin{array}{r}\text { Richness } \\
\end{array}$} \\
\hline & \multicolumn{3}{|c|}{ Partitioned models } & \multirow{2}{*}{$\begin{array}{c}\text { Base model: } \\
\mathrm{aR}^{2}(\%)=50 \\
\mathrm{AICc}=733.4 \\
\text { Intercept }=\mathbf{1 7 . 6}\end{array}$} & \multicolumn{3}{|c|}{ Partitioned models } & \multirow{2}{*}{$\begin{array}{c}\text { Base model } \\
\mathrm{aR}^{2}(\%)=47 \\
\mathrm{AICc}=314.6 \\
\text { Intercept }=\mathbf{3 . 7}\end{array}$} \\
\hline & & & & & & & & \\
\hline Model statistics & PPRC & $a R^{2}(\%)$ & $\triangle \mathrm{AICc}$ & PPRC & PPRC & $a R^{2}(\%)$ & $\triangle \mathrm{AICc}$ & PPRC \\
\hline Composition & & 33 & 48.3 & & & 37 & 27.1 & \\
\hline Crop $\%$ & 4.3 & & & 2.3 & 1.7 & & & 0.5 \\
\hline Natural pasture $\%$ & & & & 4.3 & & & & 1.6 \\
\hline Native remnants $\%$ & -3.2 & & & & -0.8 & & & \\
\hline Farmstead \% & 4.7 & & & 5.0 & & & & \\
\hline \multicolumn{9}{|l|}{ Summer fallow \% } \\
\hline Configuration & & 23 & 72.3 & & & 23 & 59.7 & \\
\hline Average farm size & -7 & & & & -2.0 & & & -1.4 \\
\hline Practices & & 26 & -3.4 & & & 28 & 49.1 & \\
\hline Livestock per hectare & & & & & 0.9 & & & \\
\hline \multicolumn{9}{|l|}{ Average machinery } \\
\hline \multicolumn{9}{|l|}{ Fertilizer input } \\
\hline Pesticide input & 6.0 & & & & 1.4 & & & \\
\hline
\end{tabular}


Table 3.7 Regression results for bird abundance and richness in 181 subdivisions in Ontario for A. All farmland birds B. Farmland specialists C. Farmland generalists and D. BCR 13 priority species. Only best-fit models $(p \leq 0.05$, lowest AICc) tabulated. Base model generally had the lowest AICc. PPRC = partial proportional regression coefficient (no. birds or species per point per subdivision); sum bolded. ns = no significant model

\section{Farmland Generalists (No. species $=23$ )}

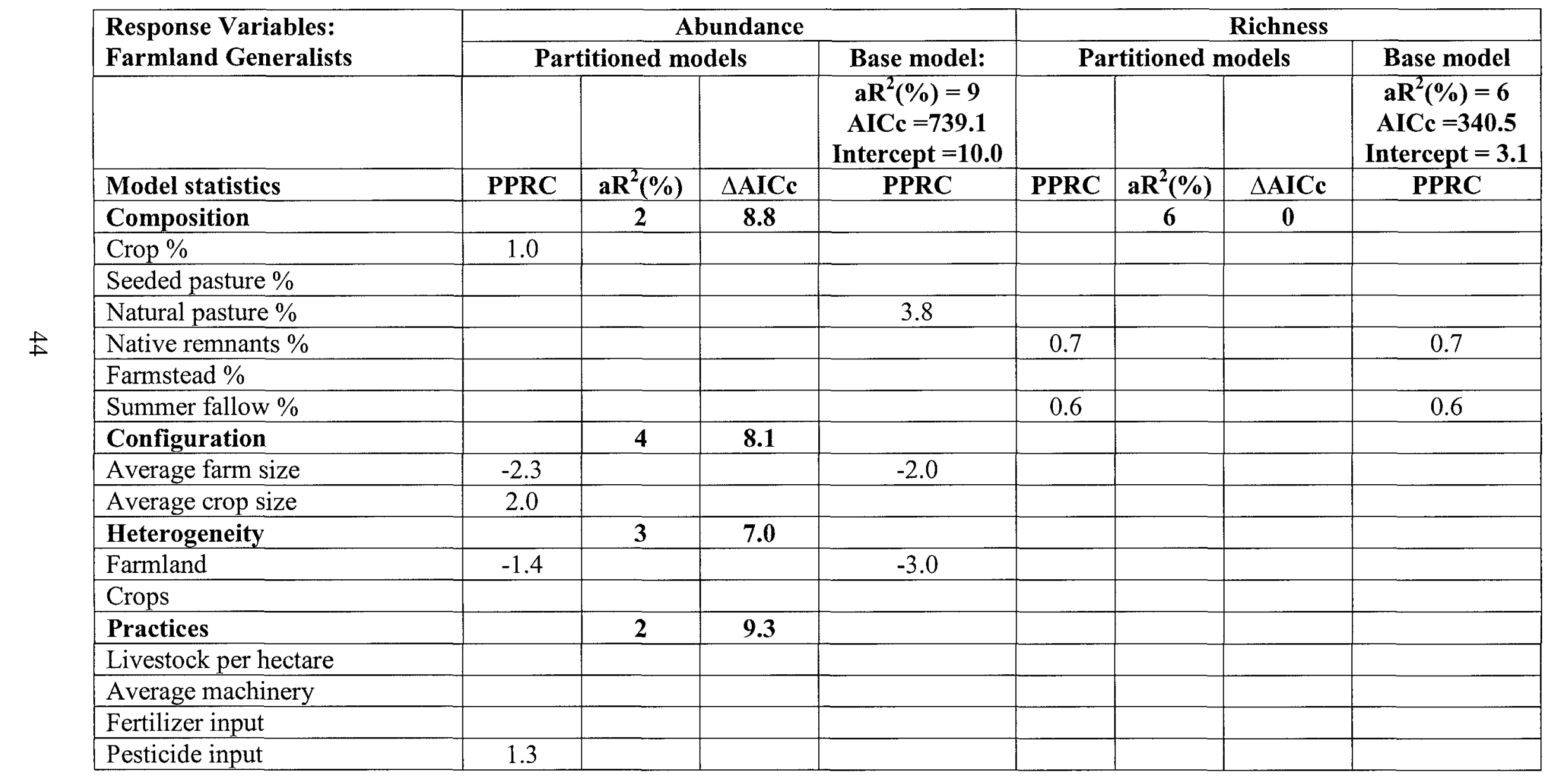


Table 3.7 Regression results for bird abundance and richness in 181 subdivisions in Ontario for A. All farmland birds B. Farmland specialists C. Farmland generalists and D. BCR 13 priority species. Only best-fit models $(p \leq 0.05$, lowest AICc) tabulated. Base model generally had the lowest AICc. PPRC = partial proportional regression coefficient (no. birds or species per point per subdivision); sum bolded.

D. BCR 13 Priority Species (No. species = 17)

\begin{tabular}{|c|c|c|c|c|c|c|c|c|}
\hline \multirow{3}{*}{$\begin{array}{l}\text { Response Variables: } \\
\text { BCR } 13 \text { Priority Species }\end{array}$} & \multicolumn{4}{|c|}{ Abundance } & \multicolumn{4}{|c|}{ Richness } \\
\hline & \multicolumn{3}{|c|}{ Partitioned models } & \multirow{2}{*}{$\begin{array}{r}\text { Base model: } \\
\mathrm{aR}^{2}(\%)=30 \\
\mathrm{AICc}=272.5 \\
\text { Intercept }=1.5\end{array}$} & \multicolumn{3}{|c|}{ Partitioned models } & \multirow{2}{*}{$\begin{array}{c}\text { Base model } \\
\mathrm{aR}^{2}(\%)=38 \\
\mathrm{AICc}=-21.3 \\
\text { Intercept }=0.4\end{array}$} \\
\hline & & 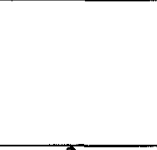 & & & & & & \\
\hline Model statistics & PPRC & $\mathrm{aR}^{2}(\%)$ & $\triangle \mathrm{AICc}$ & PPRC & PPRC & $a R^{2}(\%)$ & $\triangle \mathrm{AICc}$ & PPRC \\
\hline Composition & & 29 & 2.1 & & & 35 & 5.4 & \\
\hline Crop \% & 0.7 & & & & 0.3 & & & 0.5 \\
\hline Seeded pasture $\%$ & 1.2 & & & 1.8 & 0.5 & & & 0.9 \\
\hline Natural pasture $\%$ & 1.4 & & & 1.9 & 1.0 & & & 0.6 \\
\hline Native remnants $\%$ & & & & & & & & \\
\hline Farmstead \% & & & & & & & & \\
\hline Summer fallow \% & & & & & & & & \\
\hline Configuration & & 2 & 56.5 & $\mathbf{0}$ & & 2 & 76.1 & \\
\hline Average farm size & 0.4 & & & & 0.3 & & & -0.4 \\
\hline Average crop size & & & & & & & & \\
\hline Heterogeneity & & 0.2 & 61.3 & & & 2 & 76.4 & \\
\hline Farmland & 0.1 & & & -1.0 & 0.2 & & & -1.0 \\
\hline Crops & & & & & & & & \\
\hline Practices & & 1 & 58.4 & $\mathbf{0}$ & & 3 & 74.6 & \\
\hline Livestock per hectare & & & & & & & & -0.3 \\
\hline Average machinery & & & & & & & & \\
\hline Fertilizer input & -0.3 & & & & -0.3 & & & \\
\hline Pesticide input & & & & & & & & \\
\hline
\end{tabular}


Table 3.8 Regression results for farmland bird abundance in 181 subdivisions and in subsets with different agricultural intensity in Ontario. Only base models ( $p \leq 0.05$, lowest AICc) tabulated. PPRC $=$ partial proportional regression coefficient (no. birds per point per subdivision); sum bolded. Additional details in Appendix Table A6.

\section{A. Farmland generalists, Farmland specialists and BCR 13 priority species}

\begin{tabular}{|c|c|c|c|c|c|c|c|c|c|c|c|c|}
\hline \multirow{2}{*}{$\begin{array}{l}\text { Variables (No. spp.) } \\
\% \text { farmland }\end{array}$} & \multicolumn{4}{|c|}{ Edge Farmland Generalists (11) } & \multicolumn{4}{|c|}{ Farmland Specialists (30) } & \multicolumn{4}{|c|}{ BCR Priority Species (15) } \\
\hline & $5-94$ & $5-40$ & $40-60$ & $60-94$ & $5-94$ & $5-40$ & $40-60$ & $60-94$ & $5-94$ & $5-40$ & $40-60$ & $60-94$ \\
\hline \# subdivisions & 181 & 59 & 54 & 68 & 181 & 59 & 54 & 68 & 181 & 59 & 54 & 68 \\
\hline $\mathrm{aR}^{2}(\%)$ & 13 & 34 & 18 & 17 & 43 & 56 & 11 & 20 & 30 & 13 & 25 & 50 \\
\hline \multicolumn{13}{|c|}{ PPRC } \\
\hline \multicolumn{13}{|l|}{ Composition } \\
\hline Crop \% & & & & & & 4.0 & & & & & & 0.7 \\
\hline Seeded pasture $\%$ & & & & & 3.5 & & & & 1.8 & & 1.3 & 2.2 \\
\hline Natural pasture $\%$ & 1.0 & & & 1.6 & 3.1 & & & & 1.9 & 0.7 & & 1.8 \\
\hline Native remnants $\%$ & 0.7 & 2.2 & & & & & & -3.0 & & & & \\
\hline Farmstead \% & & & & & 3.4 & & & & & & & \\
\hline \multicolumn{13}{|l|}{ Summer fallow $\%$} \\
\hline \multicolumn{13}{|l|}{ Configuration } \\
\hline Average farm size & & -1.8 & & & & & -5.6 & & & & & \\
\hline Average crop size & 1.1 & 3.3 & & & -5.1 & -6.8 & & & & & & \\
\hline \multicolumn{13}{|l|}{ Heterogeneity } \\
\hline Farmland & & & & & -10.4 & -10.0 & & & -1.0 & & & \\
\hline Crops & & & & & & & & -4.6 & & & & \\
\hline \multicolumn{13}{|l|}{ Practices } \\
\hline Livestock per hectare & & & & -1.0 & & & & & & & & \\
\hline \multicolumn{13}{|l|}{ Average machinery } \\
\hline Fertilizer input & & -1.8 & & & & & & & & & & \\
\hline Pesticide input & & & -1.8 & & & & & & & & & \\
\hline
\end{tabular}


Table 3.8 Regression results for farmland bird abundance in 181 subdivisions and in subsets with different agricultural intensity in Ontario. Only base models ( $p \leq 0.05$, lowest AICc) tabulated. PPRC $=$ partial proportional regression coefficient (no. birds per point per subdivision); sum bolded. Additional details in Appendix Table A6.

\section{B. Row crop specialists, Pasture specialists and Farmstead specialists}

\begin{tabular}{|c|c|c|c|c|c|c|c|c|c|c|c|c|}
\hline \multirow{2}{*}{$\begin{array}{l}\text { Variables (No spp.) } \\
\% \text { farmland }\end{array}$} & \multicolumn{4}{|c|}{ Row crop specialists (6) } & \multicolumn{4}{|c|}{ Pasture specialists (12) } & \multicolumn{4}{|c|}{ Farmstead specialists (12) } \\
\hline & $5-94$ & $5-40$ & $40-60$ & $60-94$ & $5-94$ & $5-40$ & $40-60$ & $60-94$ & $5-94$ & $5-40$ & $40-60$ & $60-94$ \\
\hline \# subdivisions & 181 & 59 & 54 & 68 & 181 & 59 & 54 & 68 & 181 & 59 & 54 & 68 \\
\hline $\mathrm{aR}^{2}(\%)$ & 56 & 56 & 23 & 24 & 46 & 27 & 22 & 55 & 42 & 59 & 21 & 32 \\
\hline \multicolumn{13}{|c|}{ PPRC } \\
\hline \multicolumn{13}{|l|}{ Composition (Sum) } \\
\hline Crop \% & 1.2 & 0.2 & & 1.0 & 0.5 & 0.7 & & 0.6 & & & & \\
\hline Seeded pasture $\%$ & & & & & 2.7 & & 1.2 & 2.2 & & & -3.3 & \\
\hline Natural pasture $\%$ & & & & & 1.0 & 0.4 & & 1.5 & & & & \\
\hline Native remnants $\%$ & -0.2 & -0.1 & -0.1 & & -0.4 & & & & & & & \\
\hline Farmstead \% & -0.4 & & & & & & & & 3.9 & 3.3 & & \\
\hline Summer fallow \% & & 0.1 & & & & & & & & & & \\
\hline \multicolumn{13}{|l|}{ Configuration (Sum) } \\
\hline Average farm size & & & & & & & & & & & -4.2 & \\
\hline Average crop size & & & & & & & & & -4.4 & -6.8 & & -3.5 \\
\hline \multicolumn{13}{|l|}{ Heterogeneity (Sum) } \\
\hline Farmland & & & & & & & & & -7.5 & -12.0 & & \\
\hline Crops & -0.2 & & & & & & & & & & & \\
\hline \multicolumn{13}{|l|}{ Practices (Sum) } \\
\hline Livestock per hectare & & & 0.2 & & & & & & & & & \\
\hline \multicolumn{13}{|l|}{ Average machinery } \\
\hline Fertilizer input & & & & & & -0.6 & & & & & & -5.0 \\
\hline Pesticide input & & & & & & & & & & & & 9.4 \\
\hline
\end{tabular}



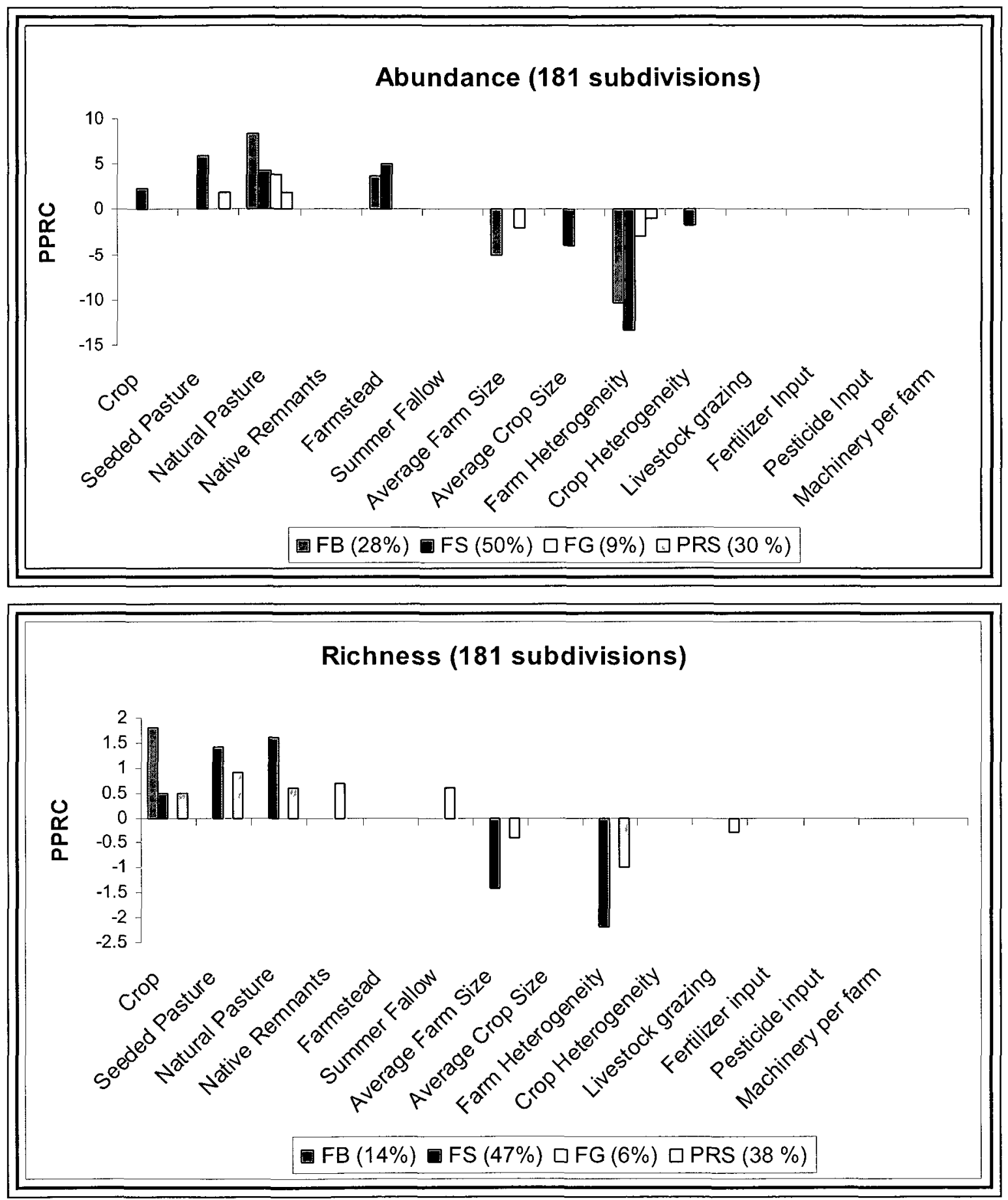

Figure 3.1 Numerical response of farmland bird abundance and richness to farmland structure and practices in 181 subdivisions in Ontario. $\quad$ PPRC $=$ partial proportional regression coefficient (change in the number of birds or species per point per subdivision). Legend: $\mathrm{FB}=$ all farmland birds, $\mathrm{FG}=$ farmland generalists, FS = farmland specialists, PRS = BCR 13 priority species, $(\%)=$ percent variance explained by base model. 


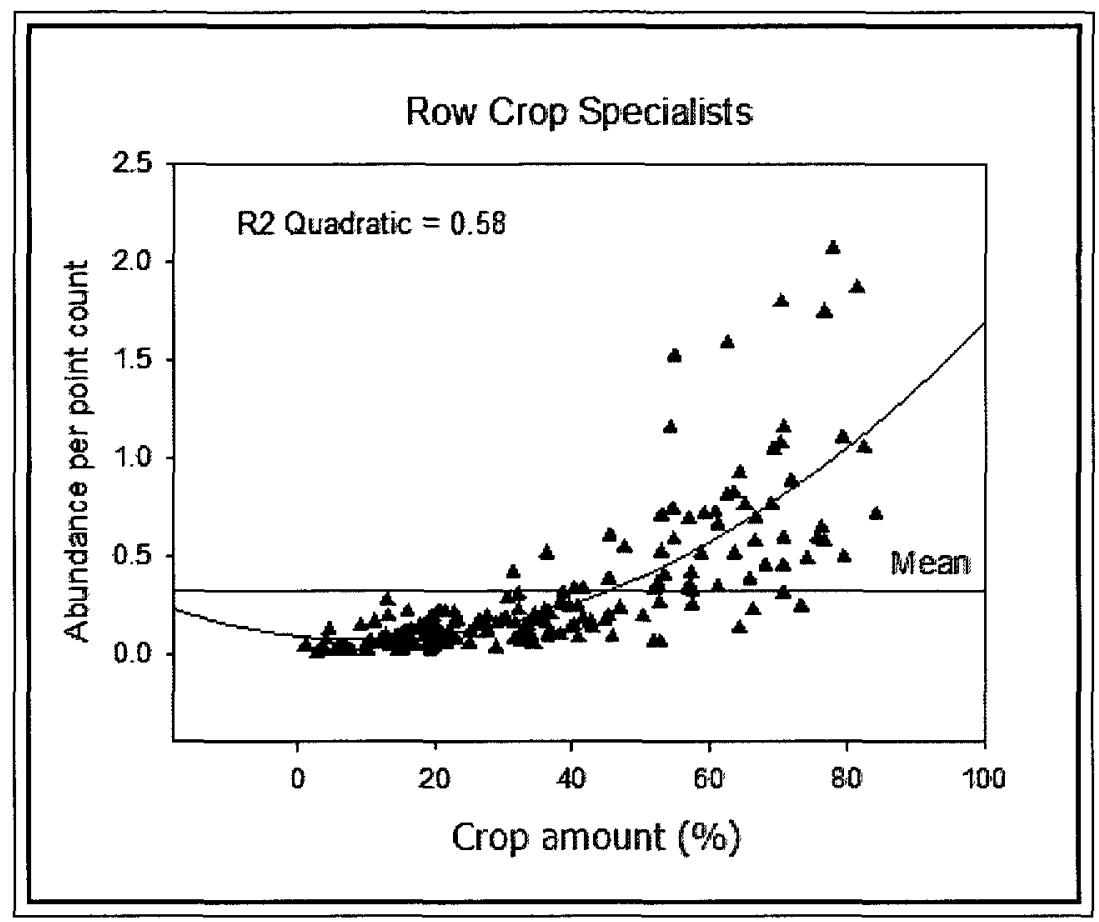

Figure 3.2 Abundance-habitat relationship for row crop specialists (6 species) in 181 subdivisions in Ontario. R2 = proportion of variance explained.

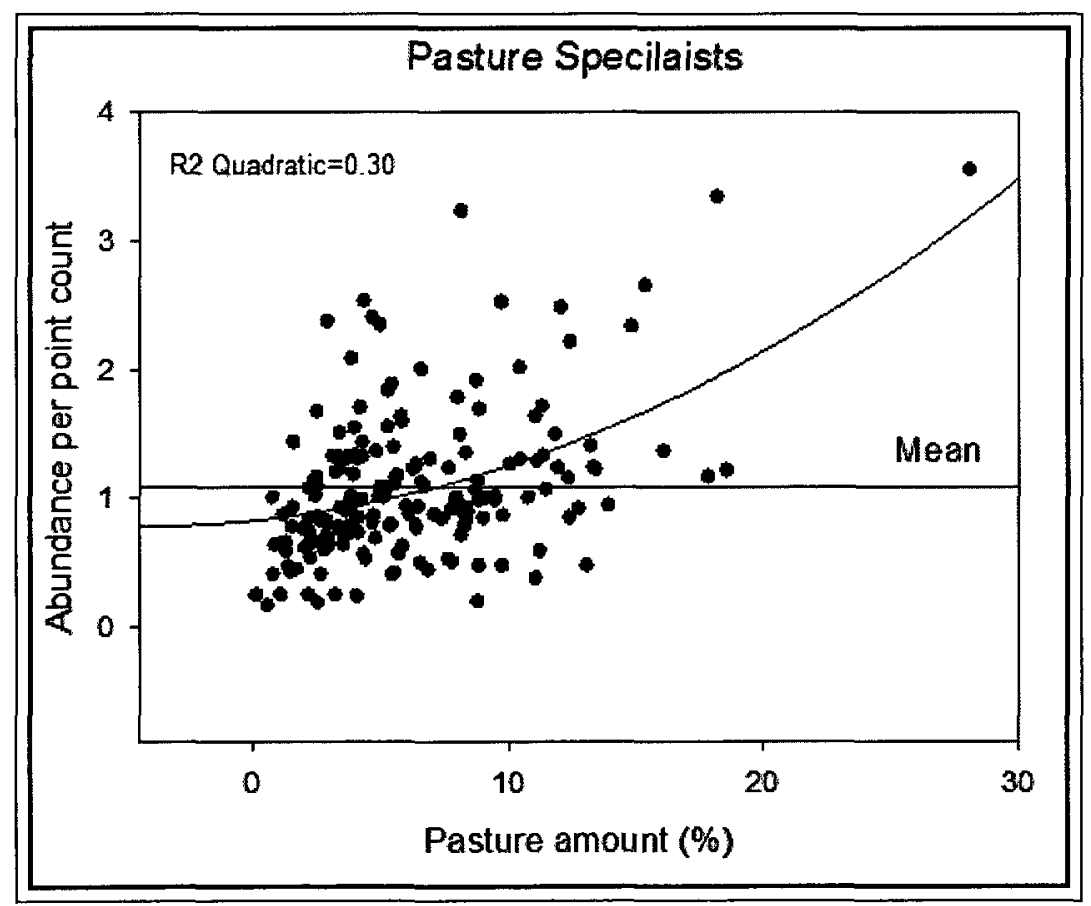

Figure 3.3 Abundance-habitat relationship for pasture specialists (11 species) in 181 subdivisions in Ontario.. Pasture amount $=$ percent area of subdivision in natural + seeded pasture. $\mathrm{R} 2=$ proportion of variance explained. 


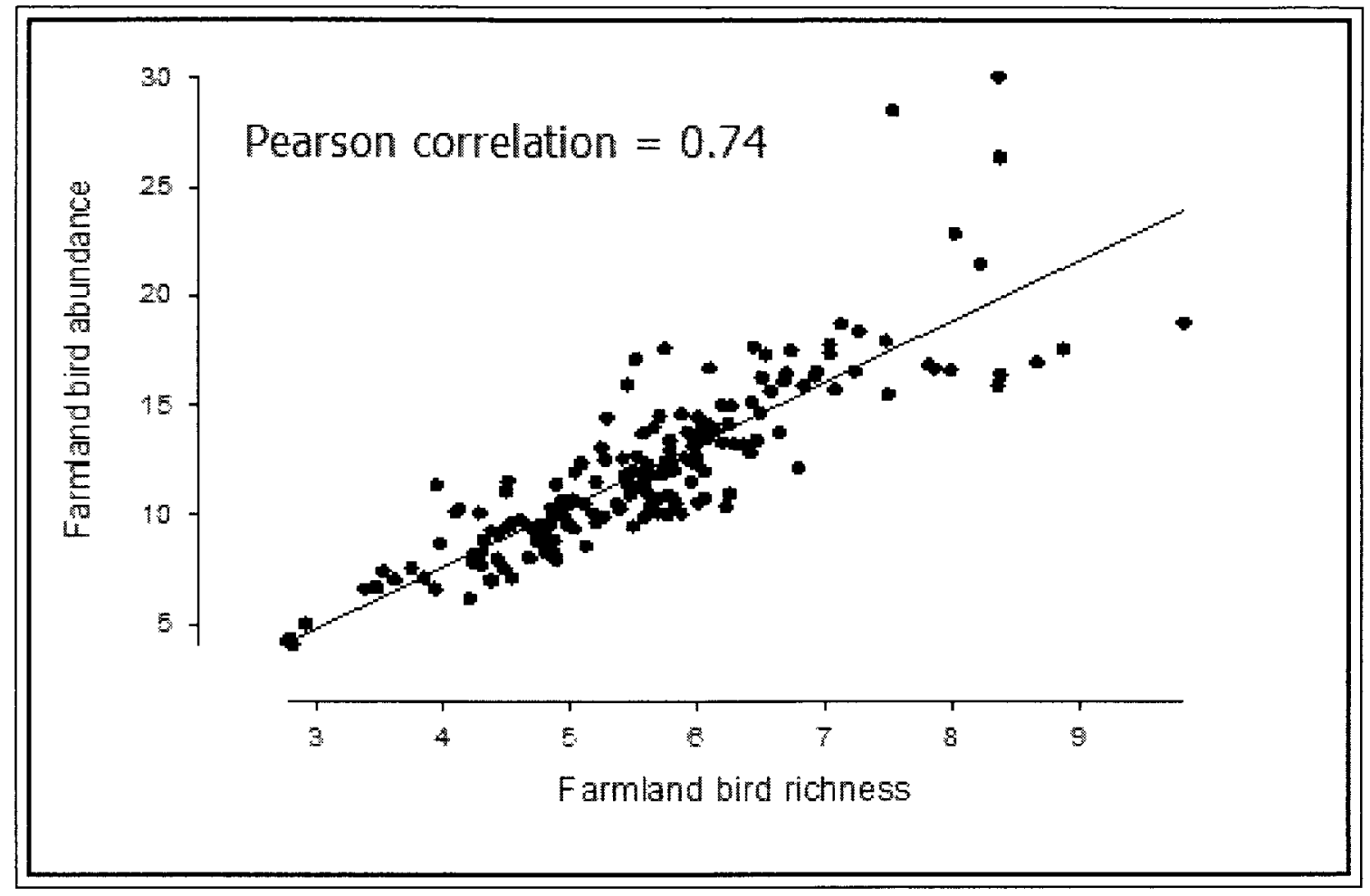

Figure 3.4 Relationship between farmland bird abundance and richness per point count in 181 subdivisions in Ontario. 


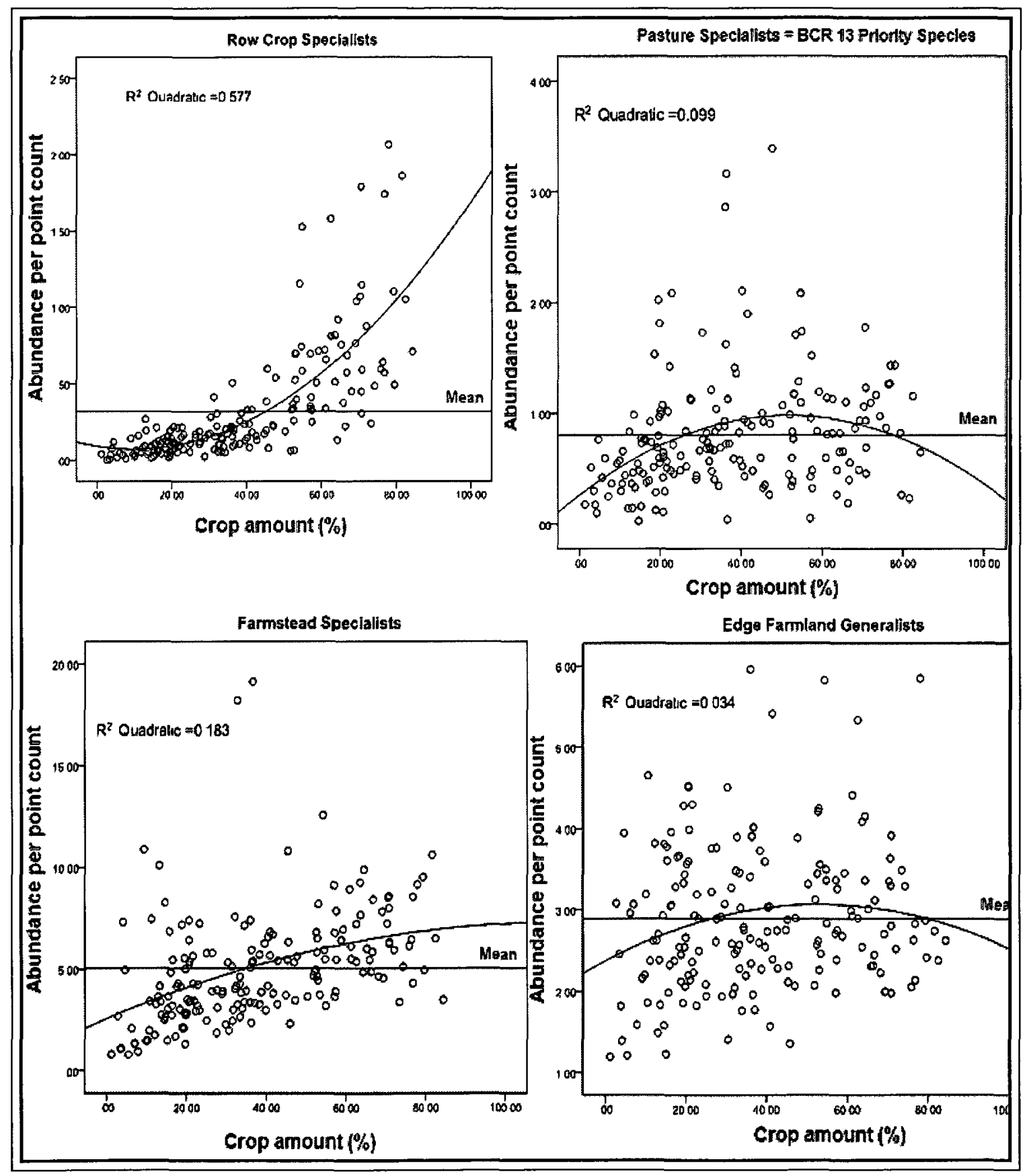

Figure 3.5 Relationships between farmland bird abundance and row crop area for 181 subdivisions in Ontario. Amount $=$ percent subdivision area in row crops. $\mathrm{R} 2=$ proportion of variance explained. $\mathrm{BCR} 13$ priority species $(\mathrm{R} 2=0.10)$. 


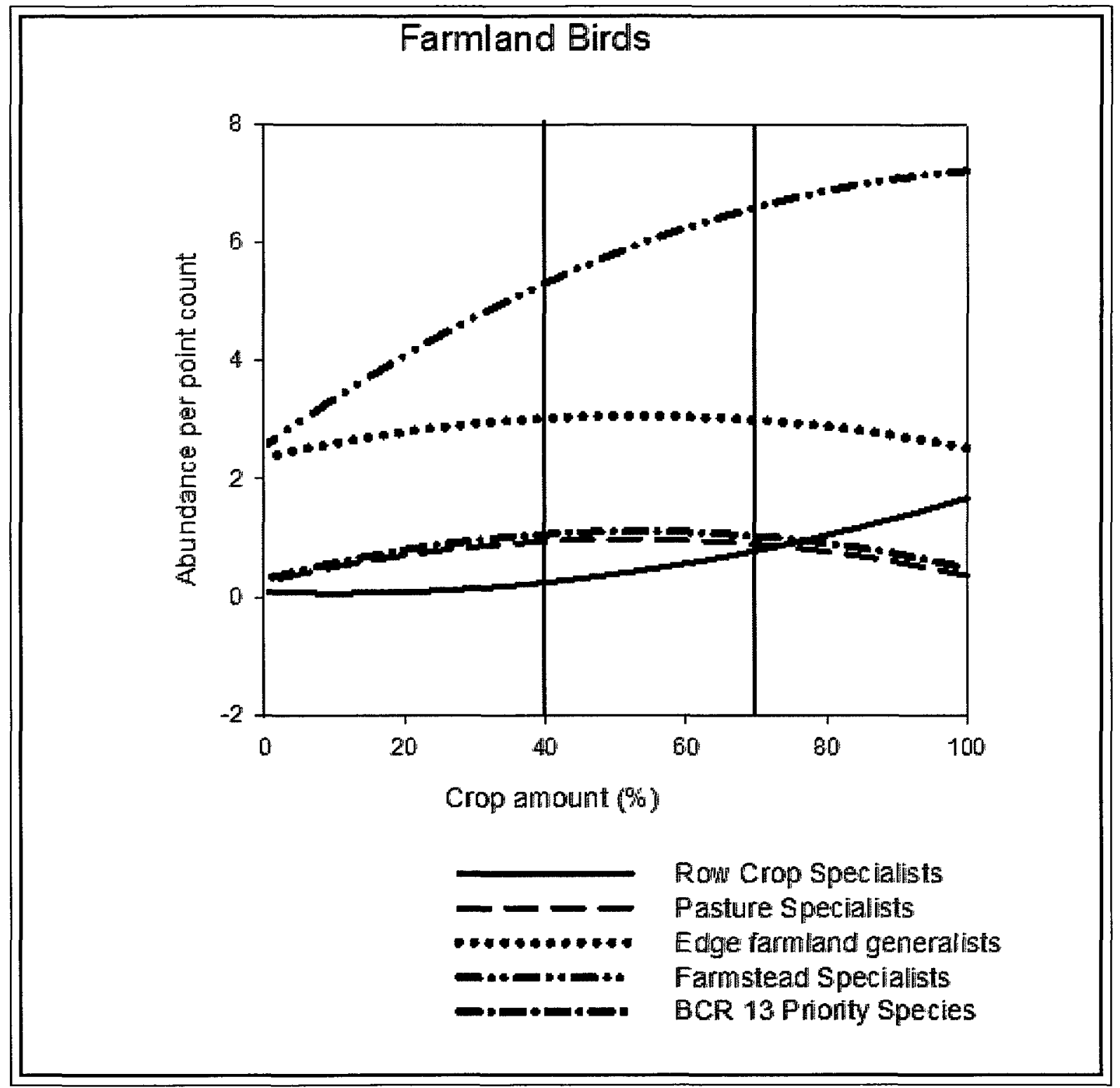

Figure 3.6 Modeled responses of farmland birds to farmland composition in Ontario. Crop amount $=$ percent area of subdivision in row crop. 


\section{Discussion}

Previous studies in North America have primarily focused on temporal trends in grassland birds in relation to agriculture. This thesis has extended this focus to one on farmland birds using a spatial framework at a single point in time for birds in Ontario and subsetting datasets to explore effects of agricultural intensification. Currently, agriculture is a dominant land use in southern Ontario, occupying two-thirds of all land cover. Historically, over $90 \%$ of southern Ontario was covered by deciduous and mixed woodlands even in the early 1800 s. However, between the mid-1700s and the early 1900 s about $90 \%$ of the landscape was converted to agricultural production. Not surprisingly, the statistics of natural habitat loss in southern Ontario reflect this trend with $68 \%$ of wetlands 10 st, $97 \%$ of prairie and savannah habitats, and $94 \%$ of the original upland woodland (OPF 2005). Despite the loss of natural grassland habitats, traditional smallscaled farming practices had created suitable surrogate habitats for grassland species, which have resulted in the expansion of historical ranges (Birds of North America 2009). Over the last 40 years, many grassland and other open-country species have shown negative population trends (OPF 2005).

\section{Categorization of farmland birds}

The European approach (EBCC 2009) differentiates farmland birds as either specialists or generalists in relation to their use of farmland within agricultural landscapes. This categorization was applied to species in North America based on the literature and expert opinion. Julliard et al. (2006) argue that a more powerful method is to use quantitative analysis of abundance patterns a priori to categorize species 
specialization because it is more efficient and less subjective. In the present study, regression analysis was used to validate and refine species categorization and to further categorize species by association with row crop, pasture, farmstead and edges. This further categorization turned out to be important for understanding the differential distribution of species in response to landscape-scale effects within farmland.

The final list of farmland bird for Ontario includes 45 species, comprised of 34 specialists ( 6 row crop, 16 pasture and 12 farmstead) and 11 edge generalists. This is comparable to the list of farmland birds for EU which includes 36 specialists. As done in the current study, Ahnstrom et al. (2008) categorize species that use farmsteads in Sweden as specialists based on their dependence on human habitations for breeding. However, regression results for this set of species suggested that they could alternatively be categorized as farmstead generalists, because while strongly associated to farmstead, they also responded strongly to configuration, heterogeneity and practices as did edge generalists and farmland generalists overall. Furthermore, many farmstead species also occur in urban and suburban areas (Birds of North America 2009). Clavel et al. (2010) would likely categorize them as generalists based on the breadth of their habitat use. They might also re-categorize edge generalists as edge specialists given their preferred use of habitat edges. The choice of categorization is important because it influences what conservation actions are most appropriate when species become of concern.

\section{Effects of farmland structure and agricultural practices}

The current analysis represents $84 \%$ of all farmland in Ontario. Landscape structure (composition, configuration, heterogeneity) was found to be more important 
than practices for richness and abundance of farmland birds, a finding consistent with the review of the existing literature. Within landscape structure, composition variables were significant in all base models for both the abundance and richness of farmland birds. The primary importance of farmland composition has been observed in other, more local studies in Ontario (Freemark \& Kirk 2001) and in Europe (Billeter et al. 2008). At the same time, as it would be expected, farmland specialists showed a stronger response to farmland composition than generalists. Farmland specialists exhibited positive associations with crop, pastures and/or farmstead, and negative with native remnants, results that are consistent with other studies (e.g., Heikkinen et al. 2004; Ribic et al. 2009b). A habitat-based standard for row crop and pasture specialists was evident with higher than average abundances at about $40 \%$ crop and $8 \%-10 \%$ pasture, respectively. Both the richness and abundance of farmland generalists (including edge generalists) were associated with a variety of cover types in farmland including a positive association with native remnants.

Greater heterogeneity was found to have negative effects on both the average abundance and richness of farmland birds per point count per subdivision, especially specialists but also BCR 13 priority species. These findings appear contrary to other studies which have found that bird richness increases with farmland diversity (Benton et al. 2003, Van Turnhout et al. 2007, Vepsalainen 2007, Herzon et al. 2008, Wretenberg et al. 2010) but may in part be due to methodological differences. The effect of heterogeneity on beta diversity (change in species composition among points) still needs to be investigated for Ontario. The observed negative effect of heterogeneity on farmland bird abundance is consistent with the existing literature (Herzon et al. 2008, 
Wretenberg et al. 2010) and, based on the subset analysis, may be a result of negative effects particularly in the least intensively- farmed subdivisions, perhaps as a result of habitat patches being too small to be useful. Potential bias in the point count data analysis may also be a factor in subdivisions with low amounts of farmland. Farmland heterogeneity appeared to be more important than heterogeneity in crop types., a finding that is consistent with other studies (Fillipi-Codaccioni et al. 2010b). However, farmland heterogeneity was the variable with the most colinearity. The role of crop heterogeneity merits further research, especially at finer levels of resolution.

Configuration was important to those farmland birds that specialize on edge habitats (edge farmland generalists) or need production areas in close proximity to their breeding habitat (e.g. farmstead specialists). Larger field size has been found to have an adverse effect on bird richness in other studies in Ontario (Freemark and Kirk 2001) and in Europe (Vickery et al. 2004, Belfrage et al. 2005, Kati \& Sekersioglu 2006, Herzon et al. 2008).

Agricultural practices were only significant to the richness of BCR 13 priority species but remain important to consider for conservation action because the effect was negative.

\section{Effects of agricultural expansion and intensification}

BCR 13 priority species, row crop specialists and pasture specialists showed the strongest response to change in farmland composition in the most intensively-farmed subdivisions in Ontario. Row crop specialists increased in abundance with the expansion of farmland and habitat simplification created by agricultural intensification, a finding 
consistent with studies at field scales in Europe (Fillipi-Codaccioni et al. 2010a). BCR 13 priority species and pasture specialists showed that at least some pasture (between $8 \%-10 \%)$ in the most intensively farmed landscapes can have strong, positive effects on their abundance. Subsetting of subdivisions surfaced the importance of practices in relation to agricultural intensification, although still secondary compared to landscape structure as found by other studies (Freemark 1995, Freemark \& Boutin 1995, Askins et al. 2007). Reduction in fertilizer use should benefit edge generalists, pasture specialists and farmstead specialists; reduction in pesticide use and grazing intensity should benefit edge generalists. The positive response of farmstead specialists to pesticide inputs continues to be hard to explain and is counter to conclusions that organic farming unequivocally benefits biodiversity from reductions in pesticide use.

In the least intensively-farmed subdivisions, increasing crop size (configuration) had a positive effect on the abundance of edge generalists as noted above, suggesting a minimum patch size may well exist when farmland is not predominant. Adverse effects of configuration were only observed for farmstead specialists and were evident in all subsets, presumably due to loss of suitable foraging areas in close proximity to farmsteads.

Tradeoffs were evident across the gradient in agricultural intensity. The abundance of farmland birds was optimized when crop occupied $40 \%$ to $70 \%$ of subdivisions, presumably because all farmland birds can find their required resources. This finding is consistent with the literature review on agricultural intensification which showed adverse impacts on avian biodiversity through simplification in farmland structure and intensified management (O’Connor \& Shrubb 1986, Herzon et al. 2008). 


\section{Population trends}

Over the past 200 years, $80 \%$ of the species on the candidate list of farmland birds for North America (Appendix Table A3) have expanded their ranges in response to agricultural development based on a review of Birds of North America (2009) and is consistent with analyses by others (Murphy 2003, Peterjohn 2003, Veech 2006, Askins et al. 2007, Ribic et al. 2009a). Analysis at the continental scale of population trends since the 1960 s indicated that $62 \%$ of 43 species of farmland specialists and $17 \%$ of 36 species of farmland generalists have been declining. Askins et al. (2007) have reported continental widespread population declines for most grassland species since the 1960 s.

Based on a comparison of OBBA results from 1981-85 to 2001-2005 for BCR 13 in Ontario, 66\% of the 45 species currently proposed as farmland birds have shown population declines (Appendix Table A4). This included all row crop specialists, 80\% of pasture specialists, $64 \%$ of edge generalists and 33\% of farmstead specialists. These findings are further evidence to suggest that farmstead species are better categorized as farmstead generalists rather than specialists and edge generalists as edge specialists.

Agricultural intensification (including conversion of pastures to cropland, and earlier and more frequent haying) and field abandonment have been posited as the main drivers of recent declines (Murphy 2003, Peterjohn 2003, Nocera et al. 2005, Perlut et al. 2008). Given the observed positive effect of agricultural expansion on the abundance of row crop specialists, their population declines are likely related to demographic effects of intensification of agricultural practices as has been observed in Europe (Fillipi-Codaccioni et al. 2010a). In other words, row crops in intensively farmed landscapes are functioning as "ecological traps" (Best 1986) in that they attract birds but 
those birds are unable to reproduce at or above replacement. Edge generalists, pasture specialists, farmstead specialists and BCR 13 priority species were all found to have negative responses to practices (grazing intensity, inputs of fertilizers and inputs of pesticides except for farmstead specialists which showed a positive response) in addition to being adversely affected by loss of their preferred habitats in intensivelyfarmed landscapes. Monitoring and assessment of habitat and demography of farmland birds would help to elucidate underlying causes of population declines.

\section{Conservation implications}

One of the main problems of the $21^{\text {st }}$ century is to achieve biodiversity conservation and agricultural production goals at the same time and often in the same place (McNeely \& Scherr 2003). In Canada, the National Agri-Environmental Standards Initiative (NAESI) recently recommended retention of 25 to $30 \%$ of natural habitats within agricultural watersheds to support biodiversity of forest, riparian and grassland species (McPherson et al. 2008). In the present study, the abundance of farmland birds (including priority species and grassland species that now use pastures) was optimized when crop occupied $40 \%$ to $70 \%$ of subdivisions (with 8 to $10 \%$ pasture) leaving at least $30 \%$ of the landscape for non-farmed habitats. The current results also show that agri-environmental schemes should promote a combination of field size diversity, mixed cropping regimes, reduced grazing intensity, and reduced chemical inputs (unequivocally fertilizers) to benefit bird populations and mitigate negative effects of

agricultural intensification, findings consistent with the existing literature (Fuller et al. 2004, Henderson et al. 2009, Sanderson et al. 2009). 
Farmlands in Ontario can contribute to the conservation and management of priority bird species including many grassland species. However, $90 \%$ of all lands in southern Ontario are privately owned so conservation efforts need to support and motivate landowners' initiatives through stewardship organizations (OPF 2005). Some suggest that sustainable biodiversity conservation needs external support, such as payments for environmental services (Pagiola 2010).

The Farmland Bird Indicator in Europe is based on population trends of common breeding birds (BLI 2004). In the current study, a "space-for-time" analysis design was used to explore potential effects of land use change on farmland birds. The results suggest that a Farmland Bird Indicator would be a useful step forward for monitoring and assessment of biodiversity at multiple spatial scales in North America. The regression models produced in the present study can also be used to inform the development of conservation plans and actions for farmland birds, including for priority bird species within BCR 13.

Climate change is now recognized as one of the most powerful driving forces affecting habitats. Areas that are not currently farmed may become suitable in the future with more favourable climatic and soil conditions and increasing demand from a growing human population worldwide. Many birds including many categorized in the present study as farmland birds are beginning to expand their ranges in response to climate change (NABCI 2010). Edge generalists in particular may benefit given their flexibility to adapt and use habitats that may no longer be suitable for specialists.

The concept of environmental corridors assumes connecting of biodiversity core areas. Under climate change, agricultural areas will likely serve as range shift corridors 
facilitating bird population persistence and their seasonal movements across landscapes especially for migratory species (Galatowitch et al. 2009). Farmlands can mitigate the negative consequences of climate change impact, because they can provide food and habitat resources not only for human population, but for biodiversity as well, if they are managed not too intensively and managed by design at the landscape scale using evidence-based approaches. Knowledge of farmland bird distribution patterns and species - agriculture relationship models should inform the development of strategies for biodiversity adaptation to climate change and the design and implementation of environmentally supportive agri-environmental schemes. 


\section{References Cited}

AAFC (Agriculture and Agri-Food Canada). 2009. Agriculture and Agri-Food Canada website http://www.agr.gc.ca/ Accessed in December 2009.

Akaike, H. 1974. A new look at the statistical model identification. IEEE Transactions on Automatic Control, 19: 716-723.

Anderson, G.Q.A., D.J. Gruar, N.I. Wilkinson and R.H. Field. 2002. Three sparrow Passer montanus chick diet and productivity in an expanding colony. Birds and agriculture, Aspects of Applied Biology. Proceedings of the Association of Applied Biologists, 67: 35-42.

Anhstrom, J., A. Berg, and H. Soderlund. 2008. Birds on farmsteads - effects of landscape and farming characteristics. Ornis Fennica, 85: 98-108.

Askins, R.A., F. Chavez-Ramirez, B.C. Dale, C.A. Haas, J.R. Herkert, F.L. Knopf, and P.V. Vickery. 2007. Conservation of grassland birds in North America: Understanding Ecological Processes in Different Regions. Ornithological Monograph, 64: 1-64.

Audubon Society. 2009. State of the Birds. http://stateofthebirds.audubon.org, Accessed in September 2009.

Baldi, A. and S. Farago. 2007. Long-term changes of farmland game populations in a post-socialist country (Hungary). Agriculture, Ecosystems and Environment, 118: 307-311.

Beecher, N.A., R.J. Johnson, J.R. Brandle, R.M. Case, and L.J. Young. 2002. Agroecology of birds in organic and nonorganic farmland. Conservation Biology, 16: $1620-1631$. 
Belfrage, K, J. Bjorklund, and L. Salomonsson. 2005. The effects of farm size and organic farming on diversity of birds, pollinators, and plants in a Swedish landscape. Ambio, 34: 582-588.

Belanger, L., and M. Picard. 1999. Cattle grazing and avian communities of the St. Lawrence River Islands. Journal of Range Management, 52: 332-338.

Belfrage, K., J. Bjorklund, and L. Salomonson. 2005. The effect of farm size and organic farming on diversity of birds, pollinators, and plants in a Swedish landscape. Ambio, 34: 582-588.

Benton, T.G., J.A. Vickery and J. D. Wilson. 2003. Farmland biodiversity: is habitat heterogeneity the key? Trends in Ecology and Evolution, 18: 182-188.

Berg, A. 2002. Breeding birds in short-rotation coppices on farmland in central Sweden - the importance of Salix height and adjacent habitats. Agriculture, Ecosystems and Environment, 90: 265-276.

Best, L.B. 1986. Conservation tillage: Ecological traps for nesting birds? Wildlife Society Bulletin, 14: 308-317.

Best, L.B, K.E. Freemark, J.J. Dinsmore, and M. Camp. 1995. A review and synthesis of habitat use by breeding birds in agricultural landscapes of Iowa. American Midland Naturalist, 134: 1-29.

Best, L.B., H. Campa, K.E. Kemp, R.G. Robel, M.R. Ryan, J.A. Savidge, H.P. Weeks, and S.R. Wintershtein. 1998. Avian abundance and crop fields during winter in the Midwest. American Midland Naturalist, 139: 311-324.

Best, L.B., T.M. Bergin, and K.E. Freemark. 2001. Influence of landscape composition on bird use of rowcrop fields. Journal of Wildlife Management, 65: 442-449. 
Billeter, R., J.Liira, D. Bailey, R. Bugter, P. Arens, I. Augenstein, S. Aviron, J. Baudry, R. Bukacek, F. Burel, M. Cerny, G. De Blust, R. De Cock, T., Diekotter, H. Dietz, J. Dirksen, C. Dormann, W. Dura, M. Frenzel, R. Hamersky, F. Henderickx, F. Herzog, S. Klotz, B. Koolstra, A. Lausch, D. Le Coeur, J.P. Maelfait, P. Opdam, M. Roubalova, A. Schermann, N. Schermann, T, Schmidt, O. Schweiger, M.J.M. Smulders, M. Speelmans, P. Simova, J. Verboom, W. van Wingerden, M. Zobel, and P. Edwards. 2008. Indictors for biodiversity in aricultural ladscapes: a pan-European study. Journal of Applied Ecology, 45: 141-150.

Birds of North America. 2009. Cornell Lab of Ornithology. American Ornithological Union. http://bna.birds.cornell.edu/bna Accessed online October 2009.

BLI (BirdLife International). 2004. Birds in the European Union: a Status Assessment. Wageningen, The Netherlands, $59 \mathrm{p}$.

Boutin, C., K.E. Freemark, D.V. Weseloh, G.M. Donaldson, M. Csizy, P.A. Martin, A Wormington, J. McCracken, and D. Shepherd. 1996. Bird use of crops in Southern Ontario: Implications for assessment of pesticide risk. CWS Technical Report Series. No 284, Environment Canada, Ottawa, ON K1A OH3. 110 p.

Boutin, C., K. E. Freemark, and D.A. Kirk. 1999. Farmland birds in southern Ontario: field use, activity patterns and vulnerability to pesticide use. Agriculture, Ecosystems and Environment, 72: 239-254.

Bracken, F., and T. Bolger. 2006. Effects of set-aside management on birds breeding in lowland Ireland. Agriculture, Ecosystems and Environment, 117: 178-184. 
Bradbury, R.B., and W.B. Kirby. 2006. Farmland birds and resource protection in the UK: Cross-cutting solutions for multi-functional farming? Biological Conservation, 129: $530-542$.

Brennan, L.A., and V.P. Kuvlesky. 2005. North American grassland birds: an unfolding conservation crisis? Journal of Wildlife Management, 69: 1-13.

Buckingham, D.L., W.J. Peach, and D.S. Fox. 2006. Effect of agricultural management on the use of lowland grassland by foraging birds. Agriculture, Ecosystems and Environment, 112: 21-40.

Buenestado, F.J., P. Ferreras, M. Delibes-Mateos, F.S. Tortosa, J.A. Blanko-Aguiar, and R. Villafuerte. 2008. Habitat selection and home range size of red-legged partridges in Spain. Agriculture, Ecosystems and Environment, 126: 158-162.

Burger, L.W., D. Mackenzie, R. Thackston, and S.J. Demaso. 2006. The role of farm policy in achieving large-scale conservation: Bobwhite and buffers. Wildlife Society Bulletin, 34: 986-993.

Burel, F., J. Baudry, A. Butet, Ph. Clergeau, Y. Delettre, D. Le Coeur, F. Dubs, N. Morvan, G. Paillat, S. Petit, C. Thenail, E. Brunel, and J-C. Lefeuvre. 1998. Comparative biodiversity along a gradient of agricultural landscapes. Acta Oecologica, 19: 47-60.

Burnham, K. P., and D. R. Anderson, 2002. Model Selection and Multimodel Inference: A Practical-Theoretic Approach, 2nd ed. Springer-Verlag.

Cadman, M.D., D.A. Sutherland, G.G. Beck, D. Lepage, and A.R. Couturier (eds.). 2007. Atlas of the Breeding Birds of Ontario, 2001- 2005. Bird Studies Canada, 
Environment Canada, Ontario Ministry of Nature Resources, and Ontario Nature. Toronto, ON, Canada 706 p.

Calvo-Iglesias, M.S., U. Fra-Paleo, and R.A. Dias-Valera. 2009. Changes in farming system and population as drivers of land cover and landscape dynamics: The case of enclosed and semi-opened systems in Northern Galicia (Spain). Landscape and Urban Planning, 90: 168-177.

Chamberlain, D.E., J.D. Wilson, and R.J. Fuller. 1999. A comparison of bird populations on organic and conventional farm system in southern Britain. Biological Conservation, $88:$ 307-320.

Chamberlain, D.E., and R.J. Fuller. 2000. Local extinctions and changes in species richness of lowland farmland birds in England and Wales in relation to recent changes in agricultural land-use. Agriculture, Ecosystems and Environment, 78: 1-17.

Chamberlain, D.E. 2002. Effect of agricultural intensification on birds: Evidence from monitoring data. Birds and agriculture, Aspects of Applied Biology. Proceedings of the Association of Applied Biologists, 67: 1-10.

Chapman, R.N., D.M. Engle, R.E. Masters, and D.M. Leslie. 2004. Grassland vegetation and bird communities in the southern Great Plains of North America. Agriculture, Ecosystem and Environment, 104: 577 -585.

Clavel, J., R. Julliard, and V. Devictor. 2010. Worldwide decline of specialist species: toward a global functional homogenization? Front Ecol Environ 2010; doi:10.1890/080216. www.frontiersinecology.org Accessed online November 2010.

Colvin, B.A. 1985. Common Barn-Owl population decline in Ohio and the relationship to agricultural trends. Journal of Field Ornithology, 56: 224-235. 
Coppedge, B.R., D.M. Engle, R.E. Masters, and M.S. Gregory. 2001. Avian response to landscape change in fragmented Southern Great Plain grasslands. Ecological Applications, 11: 47-59.

Delisle, J.M, and J.A. Savidge. 1997. Avian use and vegetation characteristics of conservation reserve program fields. Journal of Wildlife Management, 61: 318-325.

Devictor, V. and F. Jiguet. 2007. Community richness and stability in agricultural landscapes. Agriculture, Ecosystems and Environment, 120: 179 -184.

Devictor, V., J. Clavel, R. Julliard, S. Lavergne, D. Mouillot, W. Thuiller, P. Venail, S. Villeger,and N. Mouket. 2010. Defining and measuring ecological specialization. Journal of Applied Ecology, 47: 15-25.

Donald, P.F., R.E. Green, and M.F. Heath. 2001. Agricultural intensification and the collapse of the Europe's farmland bird populations. Proceedings: biological sciences, 268: 25-29.

Donald, P.F., G. Pisano, M.D. Rayment, and D.J. Pain. 2002. The common agricultural policy: EU enlargement and the conservation of Europe's farmland birds. Agriculture, Ecosystems and Environment. 89: 167-182.

Donald, P. F., F.J. Sanderson, I.G. Burfield, and F.P.J. van Bommel. 2006. Further evidence of continent-wide impacts of agricultural intensification on European farmland birds, 1990-2000. Agriculture, Ecosystems and Environment, 116:189-196.

Duelli, P. 1997. Biodiversity evaluation in agricultural landscapes: An approach at two different scales. Agriculture, Ecosystems and Environment, 62: 81-91.

EBCC (European Bird Conservation Council). 2009. European Wild Bird Indicators. http://www.ebcc.info/index.php?ID=382 Accessed in October 2009. 
Farina, A. 1989. Bird community patterns in Mediterranean farmlands: A comment. Agriculture, Ecosystems and Environment, 27: 177-181.

Field, R.H., S. Benke, K. Badonyi, and R.B. Bradbury. 2007. Influence of conservation tillage on winter bird use of arable fields in Hungary. Agriculture, Ecosystems and Environment, 120: 399-404.

Filippi-Codaccioni, O., V. Devictor, Yv. Bas, J. Clobert, and R. Julliard. 2010a. Specialist response to proportion of arable land and pesticide input in agricultural landscapes. Biological Conservation, 143: 883-890.

Fillipi-Codaccioni, O., V. Devictor, Yv. Bas, and R. Julliard. 2010b. Towards more concern for specialization and less for species diversity in conserving farmland biodiversity, Biological Conservation, 143: 1493-1500.

Freemark, K., H. Dewar, and J. Saltman. 1991. A literature review of birds use of farmland habitats in the Great Lakes - St. Lawrence region. Technical Report Series, Canadian Wildlife Service, Environment Canada 114: 116 p.

Freemark, K. 1995. Assessing effects of agriculture on terrestrial wildlife: developing a hierarchical approach for US EPA. Landscape and Urban Planning, 31: 99-115.

Freemark, K. and C. Boutin. 1995. Impacts of agricultural herbicide use on terrestrial wildlife in temperate landscapes: A review with special reference to North America. Agriculture, Ecosystems and Environment, 52: 67-91.

Freemark, K.E. and D.A. Kirk. 2001. Birds on organic and conventional farms in Ontario: partitioning effects of habitats and practices on species composition and abundance. Biological Conservation, 101:337-350. 
Freemark, K.E. 2005. Farmlands for farming and nature. Pp. 193-200 In: J.A. Wiens and M.R. Moss (eds.). Issues in Landscape Ecology. Cambridge University Press, New York, USA.

Fuller, R.J. 2000. Relationships between recent changes in lowland British agriculture and farmland bird populations: an overview. Ecology and Conservation of Lowland Farmland Birds. Tring: British Ornithologists' Union, p. 5-16.

Fuller, R.J., D.E. Chamberlain, N.H.K. Burton, and S.J. Gough. 2001. Distributions of birds in lowland agricultural landscapes of England and Wales: How distinctive are bird communities of hedgerows and woodland? Agriculture, Ecosystems and Environment, 84: 79-92.

Fuller, R.J., S.A. Hinsley, and R.D. Swetnam. 2004. The relevance of non-farmland habitats, uncropped areas and habitat diversity to the conservation of farmland birds. Ibis. 146: 22-31.

Gabriel, D., S.M. Sait, J.A. Hodson, U. Schmutz, W.E. Kunin, and. T.G. Benton. 2008. Scale matters: the impact of organic farming on biodiversity at different spatial scales. Ecology Letters. Blacwell Publishing Ltd. CNRS

Galatowitch, S., L. Frelich, and L. Phillips-Mao. 2009. Regional climate change adaptation strategies for biodiversity conservation in a mid continental region of North America. Biological Conservation, 142: 2012 -2022.

Gaston, K.J., and R.A. Fuller. 2007. Biodiversity and extinction: loosing the common and the widespread. Progress in Physical Geography, 31: 213-225.

Giuliano, W.M. and S.E. Daves. 2002. Avian response to warm-season grass use in pasture and hayfield management. Biological Conservation, 106: 1-9. 
Gordon, C.E. (2000). Fire and cattle grazing on wintering sparrow in Arizona grasslands. Journal of range management, 53: $384-389$.

Grafen, A. and R. Hails. 2002. Modern Statistics for the Life Sciences. Oxford University Press Inc., New York, USA. 351 p.

Gupta, A.K. 2004. Origin of agriculture and domestication of plants and animals linked to early Holocene climate amelioration. Current Science, 87: 54-59.

Hart, J.F. 2005. Loss and abandonment of cleared farm land in the Eastern United States. Annals of the Association of American Geographers. 58: 417-440.

Heikkinen, R.K., M. Luoto, R. Virkkala, and K. Rainio. 2004. Effects of habitat cover, landscape structure and spatial variables on the abundance of birds in an agricultural - forest mosaic. Journal of Applied Ecology, 41: 824 -835.

Heinle, K., D. Alard, J. Clitherow, P. Cobb, L. Firbank, T. Kull, D. McCracken, R.F.A. Moritz, J. Niemela, M. Rebane, D. Wascher, A. Watt, and J. Young. 2008. Identifying and managing the conflicts between agriculture and biodiversity conservation in Europe - A review. Agriculture, Ecosystems and Environment, 124: $60-71$.

Henderson, I, N. Ravenscroft, G. Smith, and S. Holloway. 2009. Effects of crop diversification and low pesticide inputs on bird populations on arable land. Agriculture, Ecosystems and Environment, 129: 149-156.

Herkert, J.R. (2009). Response of bird populations to farmland set-aside programs. Conservation Biology, 23: 1036-1040

Herzog, F., S. Dreier, G. Hofer, C. Marfurt, B. Schupbach, M. Spiess, and T. Walter. 2005. Effect of ecological compensation areas on floristic and breeding bird diversity 
in Swiss agricultural landscapes. Agriculture, Ecosystems and Environment, 108: 189-204.

Herzon, I., and R.B. O'Hara. 2007. Effect of landscape complexity on farmland birds in the Baltic States. Agriculture, Ecosystems and Environment, 118: 297-306.

Herzon, I., A. Aunins, J. Elts, Z. Preiksa. 2008. Intensity of agricultural land-use and farmland birds in the Baltic States. Agriculture, Ecosystems and Environment, 125: 93-100.

Hietala-Koivu, R., J. Lankosski, and S. Tarmi. 2004. Loss of biodiversity and its social cost in an agricultural landscape. Agriculture, Ecosystems and Environment, 103: 75-83.

Horn, D.J. and R.R. Koford. 2000. Relation of grassland abundance to mowing of Conservation Reserve Program fields in North Dakota. Wildlife Society Bulletin, 28: 653-659.

Hultquist, J.M. and L.B. Best. 2001. Bird use of terraces in Iowa rowcrop fields. American Midland Naturalist, 145: 275-287.

Jepsen, J.U., C.J. Topping, P. Odderskair, and P.N. Andersen. 2005. Evaluating consequences of land-use strategies on wildlife populations using multiple-species predictive scenarios. Agriculture, Ecosystems and Environment, 105: 581-594.

Jobin, B., J.-L. DesGranges, and C. Boutin. 1996. Population trends in selected species of farmland birds in relation to recent development in agriculture in the St. Lawrence Valley. Agriculture, Ecosystems and Environment, 57: 103-116.

Jobin, B., L. Choiniere, and L. Belanger. 2001. Bird use of three types of field margins in relation to intensive agriculture in Quebec, Canada. Agriculture, Ecosystem and Environment, 84: 131-143. 
Jones, G.A., K.E. Sieving, and S.K. Jacobson. 2005. Avian diversity and functional insectivory on North-Central Florida farmlands. Conservation Biology, 19: 1234 1245.

Jones, G.A., and K.E. Sieving. 2006. Intercropping sunflower in organic vegetables to augment bird predators of arthropods. Agriculture, Ecosystems and Environment, 117: 171-177.

Johnson, D.H. and L.D. Igl. 1995. Contribution of the Conservation Reserve Program to populations of breeding birds in North Dakota. The Wilson Bulletin, 107: 709-718.

Julliard, R., J. Clavel, V. Devictor, F. Jiguet, and D. Couvert. 2006. Spatial segregation of specialists and generalists in bird communities. Ecology Letters, 9. 1237-1244.

Kati, V.I., and C.H Sekiroglu. 2006. Diversity, ecological structure, and conservation of the landbird community of Dadia reserve, Greece. Diversity and Distribution, 12: 620-629.

Kirk, D. A., C. Boutin, and K.E. Freemark. 2001. A multivariate analysis of bird species composition and abundance between crop types and seasons in southern Ontario, Canada. Ecoscience, 8:173-184.

Kleijn, D., F. Berendse, R. Smit, N. Gilissen, J. Smit, B. Brak, and R. Groeneveld. 2004. Ecological effectiveness of agri-environmental schemes in different agricultural landscapes in Netherlands. Conservation Biology, 18: 775-786.

Kleijn, D., and A. Baldi. 2005. Effects of set-aside land on farmland biodiversity: comments on Van Buskirk and Willi. Conservation Biology, 19: 963-966.

Kragten, S., K.B. Trimbos, G.R. de Snoo. 2008. Breeding skylarks (Alauda arvensis) on organic and conventional arable farms in The Netherlands. Agriculture, Ecosystems and Environment, 126: 163-167. 
Kuemmerle, T., P. Hostert, V.C. Radeloff, S. van der Linden, K. Perzanowski, and I. Kruhlov. 2008. Global change research in the Carpathian Mountain Region. Ecosystems, 11: 614-628.

Kujawa, K. 2002. Population density and species composition changes for breeding bird species in farmland woodlots in western Poland between 1964 and 1994. Agriculture, Ecosystem and Environment, 91:261 -271.

Lemoine, N., H-G. Bauer, M. Peintinger, and K. Bohning-Gauser. 2007. Effect of climate and land-use change on bird abundance in a Central European Bird Community. Conservation Biology, 21: 495-503.

Lokemoen, J.T. and J.A. Beiser. 1997. Bird use and nesting in conventional, minimumtillage, and organic cropland. The Journal of Wildlife Management, 61: 644-655.

Maisonneuve, Ch., L. Belanger, D. Bordage, B. Jobin, M. Grenier, J. Beaulieu, S. Gabor, and B. Filion. 2006. American Black Duck and Mallard distribution and habitat relationship along a forest-agriculture gradient in Southern Quebec. The Journal of Wildlife Management, 70: 450-459.

Martin, P.A. and D.J. Forsyth. 2003. Occurrence and productivity of songbirds in prairie farmland under conventional versus minimum tillage regime. Agriculture, Ecosystem and Environment, 96: 107-117.

Matson, P.A., W.J. Parton, A.G. Power, and M.J. Swift. 1997. Agricultural intensification and ecosystem properties. Science, 277: 504-509.

Mattison, E.H.E., and K. Norris. 2005. Bridging the gaps between agricultural policy, land-use and biodiversity. Trends in Ecology and Evolution, 20: 610-616. 
McMaster, D.G., J.H. Devries, and S.K. Davis. 2005. Grassland bird nesting in haylands of Southern Saskatchewan: Landscape influence and conservation priorities. The Journal of Wildlife Management, 69: 211-221.

McNeely, J.A., and S.J. Scherr. 2003. Ecoagriculture: Strategy to Feed the World and Save Wild Biodiversity. Island Press, Washington.

McPherson, M., C. Nielson, and K. Proudlock. 2008. Tier one Standards - Generalized Habitat Standards for Ecozones within Agricultural Regions in Canada. National Agri-Environmental Standards Initiative Technical Series Report, No. 4-8: 277 p.

MEA (Millennium Ecosystem Assessment). 2005. Ecosystems and Human well-being. Biodiversity synthesis report. World Resource Institute. Washington. DC. 85 p.

Mineau, P., C.M. Downes, D.A. Kirk, E. Bayne, and M. Csizy. 2005. Patterns of bird species abundance in relation to granular insecticide use in the Canadian prairies. Ecoscience, 12: 267-278.

Mischenko, A., and O. Sukhanova. 2008. Trends of bird numbers during the habitat successions in the farmlands of Central Russia. Changes in the bird populations and numbers in the result of anthropogenic transformation of habitats and succession processes. Proceedings of the Russian Bird Conservation Union, 128 - 137.

Moulton, C.E., R.S. Brady, and J.R. Belthoff. 2006. Association between wildlife and agriculture: Underlying mechanisms and implications in Burrowing Owls. The Journal of Wildlife Management, 70: 708-716.

Murphy, M. T. 2003. Avian population trends within the evolving agricultural landscape of Eastern and Central United States. Auk, 120: 20-34. 
NABCI (North American Bird Conservation Initiative U.S. Committee). 2010. The State of the Birds 2010 Report on Climate Change,. U.S. Department of the Interior: Washington, DC, USA.

Newton, I. 2004. The recent declines of farmland bird populations in Britain: an appraisal of casual factors and conservation actions. Ibis, 146: 579-600.

Nikolov S.C. 2010. Effects of land abandonment and changing habitat structure on avian assemblages in upland pastures of Bulgaria. Bird Conservation International, 20: $200-213$.

Noble, D.G. and M.J. Raven. 2002. Regional trends in farmland birds in UK. Birds and agriculture, Aspects of Applied Biology. Proceedings of the Association of Applied Biologists, 67: $141-146$.

Nocera, J.J., G.J. Parsons, G.R. Milton, and A.H. Fredeen. 2005. Compatibility of delayed cutting regime with bird breeding and hay nutritional quality. Agriculture, Ecosystem and Environment, 107: 245-253.

NRC (Natural Resources Canada). 2010. Climate Change Impacts and Adaptation. http://adaptation.nrcan.gc.ca/perspective/summary Accessed in September 2010.

O'Connor, R.J., and M. Shrubb. 1986. Farming and birds. Cambridge university press. Oxford. UK. 290 p.

Ogden, L.J.E., Sh. Bittman, D.B. Lank, and F.C. Stevenson. 2008. Factors influencing farmland habitat use by shorebird wintering in the Fraser River Delta, Canada. Agriculture, Ecosystems and Environment, 124: 252-258. 
OMAFRA (Ontario Ministry of Agriculture, Food and Rural Affairs). 2009. Website: http://www.omafra.gov.on.ca/english/stats/agriculture_summary.htm\#area Accessed in July 2010.

OPF (Ontario Partners in Flight). 2005. Ontario LandBird Conservation Plan: Lower Great Lakes/ St. Lawrence Plain (North American Bird Conservation Region 13), Priorities, Objectives and Recommended Actions. Environment Canada/ Ministry Nature Resources. 15 p.

Padoa-Schioppa, E., M. Baietto, R. Massa, and L. Bottoni. 2006. Bird communities as bioindicators: The focal species concept in agricultural landscapes. Ecological Indicators, 6: 83-93.

Pagiola, S. 2010. Saving biodiversity - debate. IUCN - World Conservation Magazine. July 2010. http:/www.iucn.org/knowledge/publications_doc/world_conservation/ Accessed online August 2010.

Pascual, J.A., A.D.M. Hart, P.J. Saunders, H.V. McKay, J. Kilpatrick, and P. Prosser. 1999. Agricultural methods to reduce the risk to birds from cereal seed treatments on fenlands in Eastern England: Sowing depth manipulation. Agriculture, Ecosystems and Environment, 72: 59-73.

Peach, W.J., L.J. Lovett, S.R. Wotton, and C. Jeffs. 2001. Countryside stewardship delivers cirl bunting (Emberiza cirlus) in Devon, UK. Biological Conservation, 101: $361-373$.

Perkins, A.J., M.J. Whittingham, R.B. Bradbury, J.D. Wilson, A.J. Morris, and Ph. R. Barnett. 2000. Habitat characteristics affecting use of lowland agricultural grasslands by birds in winter. Biological Conservation, 95: 279-294. 
Perlut, N.G., A.M. Strong, T.M. Donovan, and N.J. Buckley. 2008. Regional population viability of grassland songbirds: Effects of agricultural management. Biological Conservation, 141: 3139-3151.

Peterjohn, B.J. 2003. Agricultural landscapes: can they support healthy bird populations as well as farm products? Auk, 120: 14-19.

Piha, M., J. Tiainen, J. Holopainen, and V. Vepsalainen. 2007. Effects of land use and landscape characteristics on avian diversity and abundance in a boreal agricultural landscape with organic and conventional farms. Biological Conservation, 140: 50 -61.

Puckett, H.L., J.R. Brandle, R.J. Johnson, and E.E. Blankenship. 2009. Avian foraging patterns in crop field edges adjacent to woody habitat. Agriculture, Ecosystem and Environment, 131:9-15.

Pueyo, I., and S. Begueria. 2007. Modelling the rate of secondary succession after farmland abandonment in a Mediterranean mountain area. Landscape and Urban Planning, 83: 245-254.

Ribic, Ch., R.R. Conford, J.R. Herkert, D.H. Johnson, N.D. Niemuth, D.E. Naugle, K.K. Bakker, D.W. Sample, and R.B. Ranfrew. 2009a. Area sensitivity in North American grassland birds: patterns and processes. Auk, 14: 233- 244.

Ribic, Ch.A., M.J. Guzy, and D.W. Sample. 2009b. Grassland bird use of remnant prairies and Conservation Reserve Program fields in an agricultural landscape in Wisconsin. American Midland Naturalist, 161: 110-122.

Rodgers, R.D. 2003. Effect of wheat-stubble height and weed control on winter pheasant abundance. Wildlife Society Bulletin, 30: 1099-1112. 
Rodriguez, J.P. 2002. Range contraction in declining North American bird populations. Ecological Applications, 12: 238-248.

Rodriguez, C. and K. Wiegand. 2009. Evaluating the trade-off between machinery efficiency and loss of biodiversity-friendly habitats in arable landscapes: The role of field size. Agriculture, Ecosystems and Environment, 129: 361-366.

Sampson, F.B. and F.L. Knopf. 1994. Prairie conservation in North America. BioScience, 44: 418-421.

Sanderson, F.J., A. Kloch, K. Sachanowicz, and P.F. Donald. 2009. Predicting the effect of agricultural change on farmland bird population in Poland. Agriculture, Ecosystems and Environment, 129: 37-42.

Sauberer, N., K. Zulka, M. Abensperg-Traun, H-M. Berg, G. Bieringer, N. Milasowszky, D. Moser, Ch. Plutzar, M. Pollheimer, Ch. Storch, R. Trostl, H. Zechmeister, and G. Grabherr. 2004. Surrogate taxa for biodiversity in agricultural landscapes of eastern Austria. Biological Conservation, 117: 181 -190.

Scholefield, P., L. Firbrank, S. Butler, K. Norris, L.M. Jones, and S. Petit. 2010. Modelling the European Farmland Bird Indicator in response to forecast land-use change in Europe. Ecological Indicators, 11: 46-51.

Sirami, C., L. Brotons, I. Burfield, J. Fonderflick, and J-L. Martin. 2008. Is land abandonment having an impact on biodiversity? Biological Conservation, 141: 450459.

Siriwardena, G.M., S.R. Baillie, H.Q.P. Crick, and J.D. Wilson. 2001. Changes in agricultural land-use and breeding performance of some granivorous farmland passerins in Britain. Agriculture, Ecosystems and Environment, 84: 191 - 206. 
Smith, A.C. 2010. Prioritizing Management Options for Conservation, with Applications in Avian Landscape Ecology. Ph.D. Thesis. Dept.Biology, Carleton University, Ottawa, Canada. 175 p.

Sotherton, N.W. 1998. Land use changes and the decline of farmland wildlife: an appraisal of the set-aside approach. Biological Conservation, 83: 259-268.

Spark, T.H., T. Parish, and S.A. Hinsley. 1996. Breeding birds in field boundaries in an agricultural landscape. Agriculture, Ecosystems and Environment, 60: 1-8.

Statistics Canada. 2009. Census of Agriculture 2006. www.statcan.gc.ca

Stevens, D.K., and R.B. Bradbury. 2006. Effect of the Arable Stewardship Pilot Scheme on breeding birds at field and farm scales. Agriculture, Ecosystems and Environment, 112: $283-290$.

Swagemakers, P., H. Wiskerke, and J.D. Van Der Ploeg. 2009. Linking birds, fields and farmers. Journal of Environmental Management, 90: 185 -192.

Teyssedre, A., and D. Couvet. 2007. Expected impact of agriculture expansion on the world aviafauna. C.R. Biologies, 330: 247-254.

Tucker, G.M., and M.I. Evans. 1997. Habitats for birds in Europe: a conservation strategy for the wider environment. BirdLife International. Cambridge, UK.

Turvey, J. and B. Koney. 2006. Ontario's agricultural policies, sustainable urban communities and the greenbelt. Post World Planners Congress: Planning for food seminar. 39 p.

Vandermeer, J., M. one Noordwijk, J. Anderson, Ch. Ong, and I. Perfecto. 1998. Agriculture, Ecosystems and Environment, 67: 1-22. 
Van Turnhout, Ch.A.M., R.P.B. Foppen, R.S.E.W. Leuven, H. Siepel, and H. Esselink. 2007. Scale-dependent homogenization: Changes in breeding bird diversity in the Netherlands over a 25-year period. Biological Conservation, 134: 505-516.

Veech, J.A. 2006. A comparison of landscapes occupied by increasing and decreasing populations of grassland birds. Conservation Biology, 20: 1422-1432.

Vepsalainen, V. 2007. Farmland Birds and Habitat Heterogeneity in Intensively Cultivated Boreal Agricultural Landscapes. PhD thesis (Academic Dissertation), Helsinki University, Helsinki, Finland. 52 p.

Verhulst, J., A. Baldi, and D. Kleijn. 2004. Relationship between land-use intensity and species richness and abundance of birds in Hungary. Agriculture, Ecosystems and Environment, 104: 465-473.

Vickery, J.A., R.B. Bradbury, I.G. Henderson, M.A. Eaton, and Ph. V. Grice. 2004. The role of agri-environment schemes and farm management practices in reversing the decline of farmland birds in England. Biological Conservation, 119: 19-39.

Walker, S., R. Price, and R.T.T. Stephens. 2008. An index of risk as a measure of biodiversity conservation achieved through land reform. Conservation Biology, 22: 48-59.

Wallace, I. and M. Brklacich. 2009. Agriculture and Rural Resources. The Effects of Climate Change on Agriculture, Land Resources, Water Resources and Biodiversity. (Ed. M Walsh). Chapter 9:234-297.

Warner, R.E. 1994. Agricultural land use and grassland habitat in Illinois: Future shock for Midwestern birds? Conservation Biology, 8: 147-156. 
Warren, K.A., and J.T. Anderson. 2005. Grassland songbird nest-site selection and response to mowing in West Virginia. Wildlife Society Bulletin, 33: 285 -292.

Winter, M., D.H. Johnson, J.A. Shaffer, T.M. Donovan, and W.D. Svedarsky. 2006. Patch size and landscape effects on density and nesting success of grassland birds. The Journal of Wildlife Management, 70: 158-172.

With, K.A., A.W. King, and W.E. Jensen. 2008. Remaining large grasslands may not be sufficient to prevent grassland bird declines. Biological Conservation, 141: 31523167.

Woodhouse, S.P., J.E.G. Good, A.A. Lovett, R.J. Fuller, and P.M. Dolman. 2005. Effect of land-use and agricultural management on birds of marginal farmlands: a case study in the Llyn Peninsula, Wales. Agriculture, Ecosystems and Environment, 107: 331340.

Wretenberg, J, T. Part, and A. Berg. 2010. Changes in local species richness of farmland birds in relation to land-use changes and landscape structure. Biological Conservation, 143: 375-381. 
Appendix: Supplemental Information

Table A1 Pearson correlations among explanatory variables. All statistically significant $(p \leq 0.05)$ correlations are shaded; those above 0.500 are bolded.

\section{A. Landscapes with 5 to $94 \%$ farmlands (181 subdivisions)}

\begin{tabular}{|c|c|c|c|c|c|c|c|c|c|c|c|c|c|c|}
\hline & CROP & SFALP & TSPP & NPP & TWWP & FSAP & AVFS & AVCRS & CTPHA & FERTIN & PESTIN & AMPF & SWDIFR & SWDICR \\
\hline CROP & 1.000 & & & & & & & & & & & & & \\
\hline SFALP & .006 & 1.000 & & & & & & & & & & & & \\
\hline TSPP & -.333 & .075 & 1.000 & & & & & & & & & & & \\
\hline NPP & -.214 & .016 & -.093 & 1.000 & & & & & & & & & & \\
\hline TWWP & -.521 & .035 & -.016 & .001 & 1.000 & & & & & & & & & \\
\hline FSAP & -.308 & -.102 & .064 & -.151 & -.009 & 1.000 & & & & & & & & \\
\hline AVFS & -.216 & .179 & .118 & -.234 & .058 & .191 & 1.000 & & & & & & & \\
\hline AVCRS & .060 & -.115 & -.111 & .094 & -.046 & -.035 & -.803 & 1.000 & & & & & & \\
\hline CTPHA & -.444 & .024 & -.053 & .237 & .033 & .074 & .039 & .122 & 1.000 & & & & & \\
\hline FERTIN & .107 & .266 & -.023 & .194 & -.209 & -.053 & .015 & -.093 & -.099 & 1.000 & & & & \\
\hline PESTIN & -.233 & -.172 & .082 & .049 & .190 & -.260 & .118 & .080 & .294 & -.564 & 1.000 & & & \\
\hline AMPF & .067 & -.145 & .031 & .063 & -.159 & -.034 & -.316 & .095 & -.043 & -.121 & -.147 & 1.000 & & \\
\hline SWDIFR & .669 & -.071 & -.327 & -.175 & -.511 & -.279 & -.483 & .533 & .007 & .126 & .066 & .215 & 1.000 & \\
\hline SWDICR & -.086 & -.161 & -.120 & -.102 & .196 & .080 & .353 & -.397 & -.014 & -.298 & .137 & -.160 & -.280 & 1.000 \\
\hline
\end{tabular}


Table A2 Synopsis of studies on birds and agriculture in temperate North America

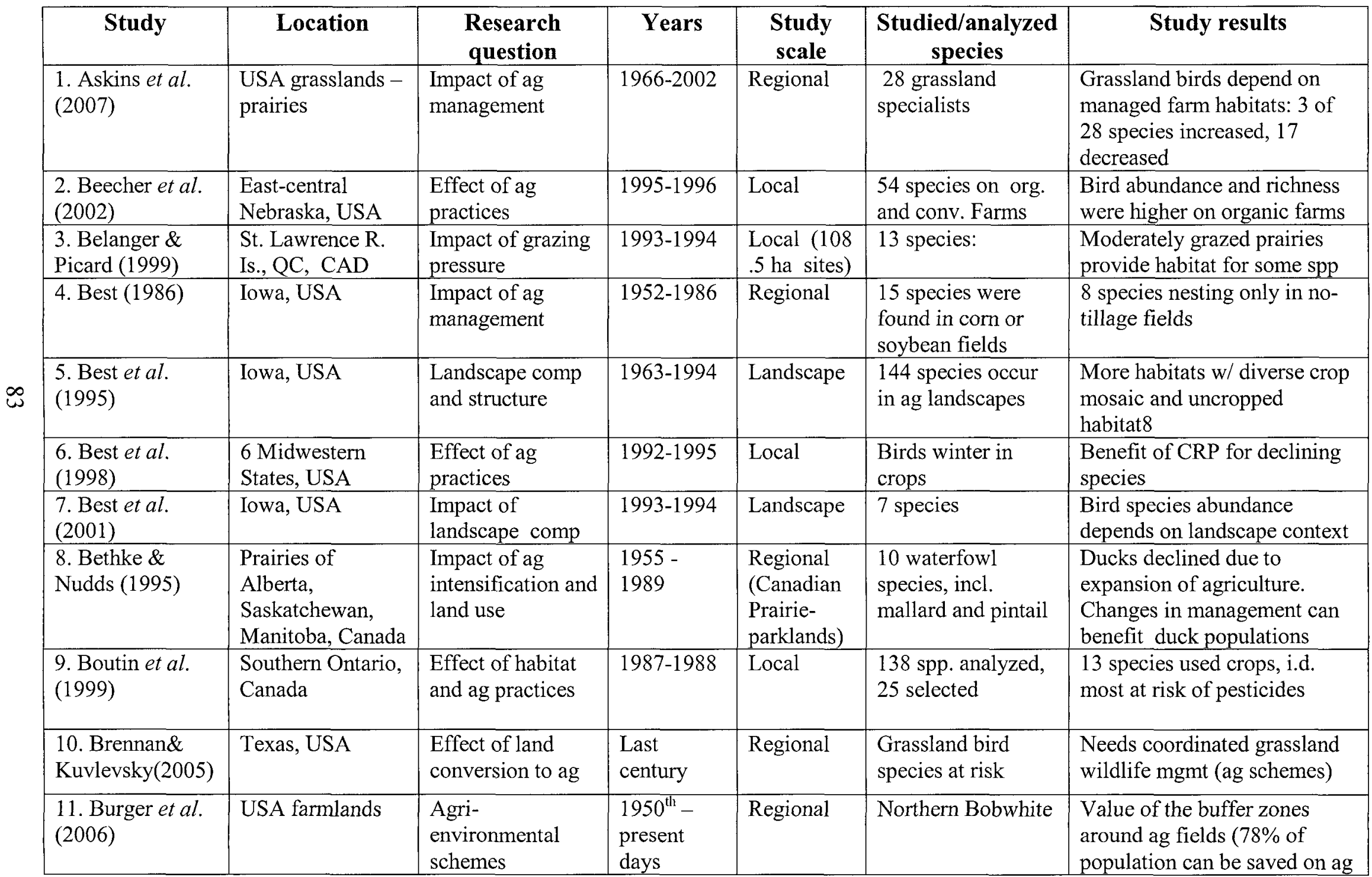




\begin{tabular}{|c|c|c|c|c|c|c|}
\hline Study & Location & $\begin{array}{l}\text { Research } \\
\text { question }\end{array}$ & Years & $\begin{array}{l}\text { Study } \\
\text { scale }\end{array}$ & $\begin{array}{c}\text { Studied/analyzed } \\
\text { species }\end{array}$ & Study results \\
\hline & & & & & & lands) \\
\hline $\begin{array}{l}\text { 12. Chapman et } \\
\text { al. (2004) }\end{array}$ & $\begin{array}{l}\text { Southern Great } \\
\text { Plains, USA }\end{array}$ & $\begin{array}{l}\text { Effect of ag } \\
\text { practices }\end{array}$ & $1998-1999$ & Local & $\begin{array}{l}\text { Grassland bird } \\
\text { species (GB) }\end{array}$ & $\begin{array}{l}\text { Seeded grasslands benefit } \\
\text { GB, but without disturbance } \\
\text { regimes few species }\end{array}$ \\
\hline 13. Colvin (1985) & Ohio, USA & $\begin{array}{l}\text { Impact of ag } \\
\text { intensification }\end{array}$ & $1931-1980$ & Regional & Barn Owl & $\begin{array}{l}\text { Changes in land use impacted } \\
\text { barn owl }\end{array}$ \\
\hline $\begin{array}{l}\text { 14. Coppedge } e t \\
\text { al. (2001) }\end{array}$ & Oklahoma, USA & $\begin{array}{l}\text { Impact of land use } \\
\text { changes }\end{array}$ & $1965-1995$ & Regional & $\begin{array}{l}\text { Grassland bird } \\
\text { (GB) community }\end{array}$ & $\begin{array}{l}\text { Conversion crops to ag } \\
\text { grassland provide suitable } \\
\text { habitat for some GB }\end{array}$ \\
\hline $\begin{array}{l}\text { 15. Delisle \& } \\
\text { Savidge (1997) }\end{array}$ & $\begin{array}{l}\text { South-eastern } \\
\text { Nebraska, USA }\end{array}$ & Effect of land use & $1991-1995$ & Local & $\begin{array}{l}\text { Grassland bird } \\
\text { species }\end{array}$ & $\begin{array}{l}\text { Effect of field size and shape } \\
\text { on the wildlife benefit of CRP }\end{array}$ \\
\hline $\begin{array}{l}\text { 16. Freemark et } \\
\text { al. (1991) }\end{array}$ & $\begin{array}{l}\text { The Great Lakes } \\
\text { region, Canada }\end{array}$ & $\begin{array}{l}\text { Literature review } \\
\text { of habitat use } \\
\text { within farm }\end{array}$ & $\begin{array}{l}\text { Since } \\
1950^{\text {th }}\end{array}$ & $\begin{array}{l}\text { Local - } \\
\text { landscape }\end{array}$ & $\begin{array}{l}\text { Birds use of } \\
\text { farmland habitat }\end{array}$ & $\begin{array}{l}58 \text { references used to identify } \\
\text { birds in farmland habitats }\end{array}$ \\
\hline $\begin{array}{l}\text { 17. Freemark \& } \\
\text { Kirk (2001) }\end{array}$ & $\begin{array}{l}\text { Southern Ontario, } \\
\text { Canada }\end{array}$ & $\begin{array}{l}\text { Effect of habitat } \\
\text { and ag practices }\end{array}$ & 1990 & Local & $\begin{array}{l}43 \text { species observed } \\
\text { on conventional } \\
\text { and organic farms }\end{array}$ & $\begin{array}{l}\text { Importance of non-cropped } \\
\text { habitats and less intensive ag } \\
\text { management }\end{array}$ \\
\hline $\begin{array}{l}\text { 18. Giuliano \& } \\
\text { Daves (2002) }\end{array}$ & $\begin{array}{l}\text { Southwest } \\
\text { Pennsylvania, } \\
\text { USA }\end{array}$ & $\begin{array}{l}\text { Effect of ag } \\
\text { practices }\end{array}$ & $1996-1997$ & Local & $\begin{array}{l}15 \text { commonly } \\
\text { observed grassland } \\
\text { birds }\end{array}$ & $\begin{array}{l}\text { Warm-season grasses benefit } \\
\text { birds in pastures and hayfields }\end{array}$ \\
\hline $\begin{array}{l}\text { 19. Gordon } \\
(2000)\end{array}$ & $\begin{array}{l}\text { Southern Arizona, } \\
\text { USA }\end{array}$ & $\begin{array}{l}\text { Effect of grazing } \\
\text { intensity }\end{array}$ & $1997-1999$ & Local & $\begin{array}{l}\text { Grassland sparrows } \\
\text { (4 species) }\end{array}$ & $\begin{array}{l}\text { Moderate cattle grazing can } \\
\text { be compatible with species } \\
\text { conservation }\end{array}$ \\
\hline $\begin{array}{l}\text { 20. Herkert } \\
(2009)\end{array}$ & $\begin{array}{l}12 \text { state regions in } \\
\text { USA }\end{array}$ & $\begin{array}{l}\text { Effect of ag } \\
\text { practices }\end{array}$ & $1966-2007$ & $\begin{array}{l}\text { Regional - } \\
\text { Landscape }\end{array}$ & $\begin{array}{l}\text { Grassland birds } \\
\text { occurrin within } \\
\text { farmlands }\end{array}$ & $\begin{array}{l}\text { Set-aside lands provide } \\
\text { population level benefits to } \\
\text { grassland birds }\end{array}$ \\
\hline $\begin{array}{l}\text { 21. Horn \& } \\
\text { Koford }(2000)\end{array}$ & $\begin{array}{l}\text { North Dakota, } \\
\text { USA }\end{array}$ & $\begin{array}{l}\text { Effect of ag } \\
\text { practices }\end{array}$ & $1997-1998$ & Local & Grassland birds & $\begin{array}{l}\text { Mowing of CRP field provide } \\
\text { mosaic of habitats for birds }\end{array}$ \\
\hline $\begin{array}{l}\text { 22. Hultquist \& } \\
\text { Best (2001) }\end{array}$ & Iowa, USA & $\begin{array}{l}\text { Effect of adjacent } \\
\text { habitat }\end{array}$ & $1996-1997$ & Local & Grassland birds & $\begin{array}{l}\text { Contribution of terraces to } \\
\text { bird conservation is minor }\end{array}$ \\
\hline 23. Jobin et al. & Southern Quebec, & Impact of ag & 1960-1992 & Regional & Farmland bird & Many species declined in the \\
\hline
\end{tabular}




\begin{tabular}{|c|c|c|c|c|c|c|}
\hline Study & Location & $\begin{array}{l}\text { Research } \\
\text { question }\end{array}$ & Years & $\begin{array}{l}\text { Study } \\
\text { scale }\end{array}$ & $\begin{array}{c}\text { Studied/analyzed } \\
\text { species }\end{array}$ & Study results \\
\hline (1996) & Canada & intensification & & - Local & $\begin{array}{l}\text { community }-28 \\
\text { species }\end{array}$ & $\begin{array}{l}\text { result of intensive farming, } \\
\text { some benefited }\end{array}$ \\
\hline $\begin{array}{l}\text { 24. Jobin et al. } \\
\text { (2001) }\end{array}$ & Quebec, Canada & $\begin{array}{l}\text { Effect of adjacent } \\
\text { habitat }\end{array}$ & 1995 & Local & Farmland birds & $\begin{array}{l}\text { Hedgerows, windbreaks and } \\
\text { herbaceous field margins } \\
\text { habitats for wildlife }\end{array}$ \\
\hline $\begin{array}{l}\text { 25. Jones et al. } \\
\text { (2005) }\end{array}$ & $\begin{array}{l}\text { North-central } \\
\text { Florida, USA }\end{array}$ & $\begin{array}{l}\text { Effect of ag } \\
\text { practices }\end{array}$ & $2000-2001$ & Local & $\begin{array}{l}\text { Birds on organic } \\
\text { and con. farms }\end{array}$ & $\begin{array}{l}\text { Farms supported } 89-96 \% \\
\text { birds breeding in the region; } \\
\text { abundances were influenced } \\
\text { by crop type and } \\
\text { heterogeneity }\end{array}$ \\
\hline $\begin{array}{l}\text { 26. Jonson \& Igl } \\
\text { (1995) }\end{array}$ & $\begin{array}{l}\text { North Dakota, } \\
\text { USA }\end{array}$ & $\begin{array}{l}\text { Effect of ag } \\
\text { practices }\end{array}$ & $\begin{array}{l}1967 ; \\
1992-1993\end{array}$ & Local & $\begin{array}{l}\text { Grassland birds } \\
\text { (GB) }\end{array}$ & $\begin{array}{l}\text { Termination of CRP may } \\
\text { cause population declines }\end{array}$ \\
\hline $\begin{array}{l}\text { 27. Kirk et al. } \\
(2001)\end{array}$ & $\begin{array}{l}\text { Southern Ontario, } \\
\text { Canada }\end{array}$ & $\begin{array}{l}\text { Effect of habitat } \\
\text { and ag practices }\end{array}$ & 1988 & Local & Farmland birds & $\begin{array}{l}\text { Importance of non-cropped } \\
\text { and cropped habitats for bird }\end{array}$ \\
\hline $\begin{array}{l}\text { 28. Lokemoen \& } \\
\text { Beiser (1997) }\end{array}$ & $\begin{array}{l}\text { Southeast North } \\
\text { Dakota, USA }\end{array}$ & $\begin{array}{l}\text { Effect of ag } \\
\text { practice }\end{array}$ & 1991-1993 & Local & Grassland birds & $\begin{array}{l}\text { Bird densities are higher on } \\
\text { minimum tillage and organic } \\
\text { fields }\end{array}$ \\
\hline $\begin{array}{l}\text { 29. Maisonneuve } \\
\text { et al. } 2006\end{array}$ & $\begin{array}{l}\text { Southern Quebec, } \\
\text { Canada }\end{array}$ & $\begin{array}{l}\text { Impact of ag } \\
\text { intensification }\end{array}$ & 1998-1999 & Local & $\begin{array}{l}\text { Mallard and } \\
\text { American black } \\
\text { duck (ABD) }\end{array}$ & $\begin{array}{l}\text { ABD was threatened by } \\
\text { conversion of native habitats } \\
\text { into cropland }\end{array}$ \\
\hline $\begin{array}{l}\text { 30. Martin \& } \\
\text { Forsyth (2003) }\end{array}$ & $\begin{array}{l}\text { Southern Alberta, } \\
\text { Canada }\end{array}$ & $\begin{array}{l}\text { Effect of ag } \\
\text { practices }\end{array}$ & 1995-1996 & Local & $\begin{array}{l}\text { Grassland bird } \\
\text { species }\end{array}$ & $\begin{array}{l}\text { Minimum tillage benefits to } \\
\text { species that nested in } \\
\text { farmlands }\end{array}$ \\
\hline $\begin{array}{l}\text { 31. McMaster et } \\
\text { al. (2005) }\end{array}$ & $\begin{array}{l}\text { Southern } \\
\text { Saskatchewan, } \\
\text { Canada } \\
\end{array}$ & $\begin{array}{l}\text { Effect of ag } \\
\text { practices }\end{array}$ & $1999-2000$ & $\begin{array}{l}\text { Local - } \\
\text { landscape }\end{array}$ & $\begin{array}{l}\text { Grassland bird } \\
\text { species ( } 26 \text { species) }\end{array}$ & $\begin{array}{l}\text { Conversion of cropland into } \\
\text { hay benefits to a variety of } \\
\text { grassland birds }\end{array}$ \\
\hline $\begin{array}{l}\text { 32. Moulton et } \\
\text { al. } 2006\end{array}$ & $\begin{array}{l}\text { South-western } \\
\text { Idaho, USA }\end{array}$ & $\begin{array}{l}\text { Factors impacting } \\
\text { the } \mathrm{BO} \\
\text { populations }\end{array}$ & $2001-2002$ & $\begin{array}{l}\text { Local - } \\
\text { landscape }\end{array}$ & $\begin{array}{l}\text { Burrowing Owl } \\
\text { (BUOW) }\end{array}$ & $\begin{array}{l}\text { Implications to management } \\
\text { of BUOW in agricultural } \\
\text { landscapes }\end{array}$ \\
\hline $\begin{array}{l}\text { 33. Murphy } \\
\text { (2003) }\end{array}$ & $\begin{array}{l}\text { Eastern and } \\
\text { Central USA }\end{array}$ & $\begin{array}{l}\text { Impact of ag } \\
\text { intensification }\end{array}$ & $1980-1998$ & Regional & Grassland birds & $\begin{array}{l}\text { Avian population changes are } \\
\text { strongly linked to ag land use }\end{array}$ \\
\hline
\end{tabular}




\begin{tabular}{|c|c|c|c|c|c|c|}
\hline Study & Location & $\begin{array}{c}\text { Research } \\
\text { question }\end{array}$ & Years & $\begin{array}{c}\text { Study } \\
\text { scale }\end{array}$ & $\begin{array}{c}\text { Studied/analyzed } \\
\text { species }\end{array}$ & Study results \\
\hline $\begin{array}{l}\text { 34. Nocera et al. } \\
(2005)\end{array}$ & $\begin{array}{l}\text { Nova Scotia, } \\
\text { Canada }\end{array}$ & $\begin{array}{l}\text { Effect of ag } \\
\text { practices }\end{array}$ & $2000-2003$ & Local & 3 grassland species & $\begin{array}{l}\text { Delaying of hayfields cutting } \\
\text { conserve breeding birds }\end{array}$ \\
\hline $\begin{array}{l}\text { 36. Ribic et al. } \\
\text { (2009b) }\end{array}$ & Wisconsin, USA & $\begin{array}{l}\text { Effect of } \\
\text { landscape }\end{array}$ & $2002-2003$ & $\begin{array}{l}\text { Local - } \\
\text { landscape }\end{array}$ & Grassland species & $\begin{array}{l}\text { Diversity of habitat types is } \\
\text { needed conserve grassland } \\
\text { birds as a group }\end{array}$ \\
\hline $\begin{array}{l}\text { 37. Rodgers } \\
(2003)\end{array}$ & $\begin{array}{l}\text { North-western } \\
\text { Kansas, USA }\end{array}$ & $\begin{array}{l}\text { Effect of ag } \\
\text { practices }\end{array}$ & $1990-1995$ & Local & $\begin{array}{l}\text { Ring-necked } \\
\text { Pheasant (RIPH) }\end{array}$ & $\begin{array}{l}\text { Row-crop stubble height and } \\
\text { unsprayed field margins } \\
\text { benefit to RIPH }\end{array}$ \\
\hline $\begin{array}{l}\text { 38. Rodriguez } \\
(2002)\end{array}$ & $\begin{array}{l}\text { North America } \\
\text { (USA, Canada) }\end{array}$ & $\begin{array}{l}\text { High human } \\
\text { impact (ag) }\end{array}$ & $1968-1993$ & Regional & $\begin{array}{l}27 \text { common bird } \\
\text { species }\end{array}$ & $\begin{array}{l}\text { Steep population declines as a } \\
\text { result of ag impact }\end{array}$ \\
\hline 39. Veech (2006) & $\begin{array}{l}\text { Midwest and } \\
\text { Great Plains, } \\
\text { USA }\end{array}$ & $\begin{array}{l}\text { Landscape } \\
\text { structure }\end{array}$ & $1982-2002$ & $\begin{array}{l}\text { Regional - } \\
\text { landscape }\end{array}$ & $\begin{array}{l}36 \text { grassland- } \\
\text { nesting bird species }\end{array}$ & $\begin{array}{l}\text { Effect of landscape } \\
\text { composition \& habitat amount } \\
\text { for grassland bird } \\
\text { conservation }\end{array}$ \\
\hline $\begin{array}{l}\text { 41. With et al. } \\
(2008)\end{array}$ & $\begin{array}{l}\text { Flint Hills, } \\
\text { Oklahoma \& } \\
\text { Kansas, USA }\end{array}$ & $\begin{array}{l}\text { Impact of } \\
\text { Landscape } \\
\text { structure }\end{array}$ & $1992-2005$ & $\begin{array}{l}\text { Regional - } \\
\text { landscape }\end{array}$ & $\begin{array}{l}3 \text { grassland species: } \\
\text { DICK, GRSP, } \\
\text { EAME }\end{array}$ & $\begin{array}{l}\text { Remnant grasslands managed } \\
\text { for ag or live stock production } \\
\text { are not sufficient to preserve } \\
\text { birds: extinction debt }\end{array}$ \\
\hline
\end{tabular}


Table A3 Candidate list of farmland birds for North America (Canada and the USA).

\begin{tabular}{|c|c|c|}
\hline Bird species & $\begin{array}{l}\text { Native } \\
\text { habitats }\end{array}$ & Farmland habitat \\
\hline Northern Bobwhite Colinus virginiatus & Grassiands & Crop/pasture \\
\hline Ring-necked Pheasant Phasianus colchicus & Grasslands & Crop/pasture \\
\hline Gray Partridge Perdle perdlx & Grasslands & Croplpasture \\
\hline American Kestrel Falco spraverius & Grassland & Crop/pasture \\
\hline Northen Harrier Cireus cianens & Grassland & \\
\hline Swainson's Hawk Buteo swainsoni & Grassland & Crop/pasture \\
\hline Killdeer Charadrus vociferous & Wet meadoi & Groppasture \\
\hline Marbled Godwit Limosa fedoa & Grassland & Crop/pasture \\
\hline Upland Sandpiper Bartramia longieaudata & (rrassland & Crop pasture \\
\hline Rock Pigeon Columba livia & Grassland rock & Crop/farmstead \\
\hline Mourning Dove Zenaida maeroura & Forest epenings & Farmsteadpastur \\
\hline Common-Ground Dove Columbina passerine & Forest edge & Crop/pasture \\
\hline Bann Owi rivto alba & Grassland & Croplpasture \\
\hline Burrowing Owl Athene cinicularia & Grassland & Crop/pasture \\
\hline Short-eared Ow 1 Asio lammeus & Openmeadow & Crop/pasture \\
\hline Common Nighthawk Chordeiles minor & Openings & Crop/pasture \\
\hline Loggerhead Shrike Lanius lidovicianus & 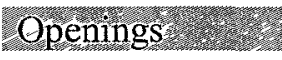 & Pasturectop \\
\hline Tree Swallow Tachycineta & Open wet areas & Farmstead/crop \\
\hline Barn Swallow Hirundo rustica & Open hills = & Famstead/pasture \\
\hline Horned Lark Eremophila alpestris & Open short grass & Crop/pasture \\
\hline House Wren Troglodytes aedon & Open woodland? & Farmsteadpasture \\
\hline European Starling Sturnus vulgaris & Openings & Farmstead/pasture \\
\hline House Sparrow Passer domestica & Grassland & Farmstead/crop \\
\hline House Finch Carpodacus mexicanus & Open areas & Farmstead/crop \\
\hline Brown headed Cowbird Molothrus ater & Grassland & Pasturectop \\
\hline Brewer's Blackbird Euphagus cyanocephalus & Open habitats & Farmstead/pasture \\
\hline Eastern Meadowlark Sturnella magna & Grassland & Pasturelerop \\
\hline Western Meadowlark Sturnella neglecta & Grassland & Pasture/crop \\
\hline Bobolink Dolichony oryzivortis & Grassland & Pasturelerop \\
\hline McCown's Longspur Calcarius mccownii & Grassland & Grazed pasture \\
\hline Chestnut-collared tongspur Calcarius ornatus? & Grassland & Grazed pasture \\
\hline Lark Bunting Calamospiza melanocorys & Grassland & Pasture/crop \\
\hline Savannah Sparrow Passerculus sanawichensis: & Grassland & Pasture crop \\
\hline Le Conte's Sparrow Ammodramus leconteii & Open meadow & Pasture/crop \\
\hline Henslow s Sparrow Ammodramus henstowil & Grassland - & Pasture/erop s \\
\hline Baird's Sparrow Ammodramus bairdii & Grassland & Pasture \\
\hline Grasshopper Sparrow Ammodramus savannarum & Grassland & Pasture \\
\hline $\begin{array}{l}\text { Clay-colored Sparrow Spizella pallid } \\
\text { Eidld Sparrow Spizella pusilla }\end{array}$ & $\begin{array}{l}\text { Shrubs/grassland } \\
\text { Grassland }\end{array}$ & $\begin{array}{l}\text { Pasture } \\
\text { Pasture crop? }\end{array}$ \\
\hline
\end{tabular}




\begin{tabular}{|c|c|c|}
\hline Vesper Sparrow Pooecetes gramineus & Open habitats & Crop/pasture \\
\hline Tark Sparrew Chondestes grammacus & Grassland & Pasturefrop \\
\hline Eastern Towhee Pipllo erythrophthalmus & Grassland & Pastur \\
\hline Diekeissel Spiza Americana & Grassland & Pasture/crop \\
\hline Wild Iurkey Melleagris gallopavo & Open forest & Edges \\
\hline Canada Goose Branta Canadensis & Wetland/meadow & Wetland/crop \\
\hline Mallard d nas platurhynchos & Wettand meadow & Range of hi \\
\hline Blue-winged Teal Anas discors & Wetlands/meadow & Wetland/p \\
\hline Northern Pintail Anas aeuta & Open meadow & Wetland/pasture \\
\hline Cattle Egret Bubulcus ibis & Wetland & Pasture/ other \\
\hline Turkey Vulture Cathartes aura & Forest openings & Pasturel other \\
\hline Red-tailed Hawk Buteo jamaicensis & Open habitats & Edges \\
\hline Ring billed Gull Larus delawarensis & Wetland & Disturbanees \\
\hline Great Horned Owl Bubo virginiatus & Openings & Woods/pasture \\
\hline $\begin{array}{l}\text { Red headed Woodiecker Melanerpes } \\
\text { erythrocephalis }\end{array}$ & $\begin{array}{l}\text { Open woods } \\
\text { clearings }\end{array}$ & Wood edges \\
\hline Northern Flicker Colaptes auratus & Open woodland & Wood edges \\
\hline Eastern Phoebe Sayornis phoebe & Edge habitats & Woods \\
\hline Eastern Wood-pewee Contopus virens & Woods & Woods \\
\hline Western Kingbird Lrannus verticalis & Open habitats & Woods \\
\hline Scissor-tailed Flycatcher Tyrannus forficatus & Open savanna & Woods \\
\hline Eastern Kinglird Thronnus turannus & Open woodland & Woods \\
\hline Great crested flycatcher Myiarchus crinitus & Open woodland & Woods \\
\hline Blue Jay cranocitta cristata & Forest & Eorest \\
\hline American Crow Corvus brachyrhynchos & Open habitats & Woods \\
\hline Cedar Waxwing Bombvcilla cedrorum & apen woodland & Woods \\
\hline Cliff Swallow Hirundo pyrrhonota & Open valleys & Edges \\
\hline Northern Mockingbird Minus polyglottes & Shrub habitat & Farmsteadredges \\
\hline Brown Thrasher Toxostoma rufum & Edge habitat & Woods \\
\hline Fastern Bluebird Sialia sialis & Open woodsedge & Woods \\
\hline American Robin Turdus migratorius & Open woods & Woods \\
\hline Ameriean Goldfinch earduelis iristis & Edge habitats - & Field margins \\
\hline Common Yellowthroat Geothlypis trichas & Thick shrubs & Woods \\
\hline Tellow breasted Chat Tcteria virens & Shrub & Abandoned fields \\
\hline Baltimore Oriole Icterus galbula & Woodland edges & Woods \\
\hline Orchard Oriole Icterusspurious & Riparian woods & Parkwoodlands \\
\hline Red-winged Blackbird Agelaius phoeniceus & Wetland & Pasture/others \\
\hline Common orackle Quiscalus quiscula & Wetland/Woods & Farmsteadothers \\
\hline Song Sparrow Melospiza melodia & Wetland/woods & Woods \\
\hline Chipping Sparrow Spizella passerine & Edge habitats & Woods \\
\hline Indigo Bunting Passerina cyanea & Edge habitats & Woods \\
\hline
\end{tabular}


Table A4 Characteristics of candidate farmland birds in Ontario. Information from references in Table A2, Birds of North America (2009) and Ontario Breeding Bird Atlas (OBBA; Cadman et al. 2007).

\section{Explanatory notes:}

* Denotes introduced species

Bold denotes priority species in Bird Conservation Region (BCR) 13

Nesting traits: $\mathrm{G}=$ ground; $\mathrm{O}=$ over-ground

Migration pattern: $\mathrm{R}=$ resident, $\mathrm{SM}=$ short-distance migrant, $\mathrm{LM}=$ long-distance migrant

Category: $\mathrm{FS}$ - farmland specialist, $\mathrm{FG}=$ farmland generalist, $\mathrm{O}=$ other

No. subdivisions: number of Census of Agriculture subdivisions $(\max =181)$ where species detected by OBBA point counts No. OBBA point counts: number of point counts at which species was detected in the 181 subdivisions

Changes between 2 OBBAs: Difference in \% probability of observation between 1981-1985 and 2001-2005 in the regions covered by the 181 subdivisions.

\begin{tabular}{|c|c|c|c|c|c|c|c|}
\hline Species & $\begin{array}{c}\text { OBBA } \\
\text { Species } \\
\text { code } \\
\end{array}$ & $\begin{array}{l}\text { Nesting } \\
\text { traits }\end{array}$ & $\begin{array}{l}\text { Migration } \\
\text { pattern }\end{array}$ & Category & $\begin{array}{c}\text { No. } \\
\text { Sub- } \\
\text { divisions }\end{array}$ & $\begin{array}{c}\text { No. OBBA } \\
\text { point } \\
\text { counts }\end{array}$ & $\begin{array}{c}\text { Changes } \\
\text { between } 2 \\
\text { OBBAs: }\end{array}$ \\
\hline Northern Bobwite Colinus virginiatus & NOBO & $\mathbf{G}$ & $\mathbf{R}$ & FS & 1 & 1 & $-65 \%$ \\
\hline Wild Turkey Melleagris gallopavo & WITU & $\mathrm{G}$ & $\mathrm{R}$ & FG & 40 & 70 & +++ \\
\hline *Grey Partridge Perdix perdix & GRPA & $\mathrm{G}$ & $\mathrm{R}$ & FS & 3 & 3 & $-44 \%$ \\
\hline Canada Goose Branta Canadensis & CAGO & $\mathrm{G}$ & SM & FG & 135 & 434 & +++ \\
\hline Northern Pintail Anas acuta & NOPI & $\mathrm{G}$ & LM & FG & 1 & 1 & $-20 \%$ \\
\hline Turkey Vulture Cathartes aura & TUVU & $\mathrm{O}$ & SM & FG & 100 & 240 & $+>50 \%$ \\
\hline American Kestrel Falco spraverius & AMKE & $\mathbf{O}$ & $\mathbf{S M}$ & FS & 76 & 153 & $-15--27 \%$ \\
\hline Northern Harrier Circus cianeus & NOHA & $\mathbf{G}$ & SM & FS & 64 & 104 & $++3-10 \%$ \\
\hline Red-tailed Hawk Buteo jamaicensis & RTHA & $\mathrm{O}$ & SM & FG & 105 & 207 & ++ \\
\hline Killdeer Charadrius vociferous & KILL & $\mathrm{G}$ & $\mathrm{SM}$ & FS & 79 & 2196 & $-36--39 \%$ \\
\hline
\end{tabular}




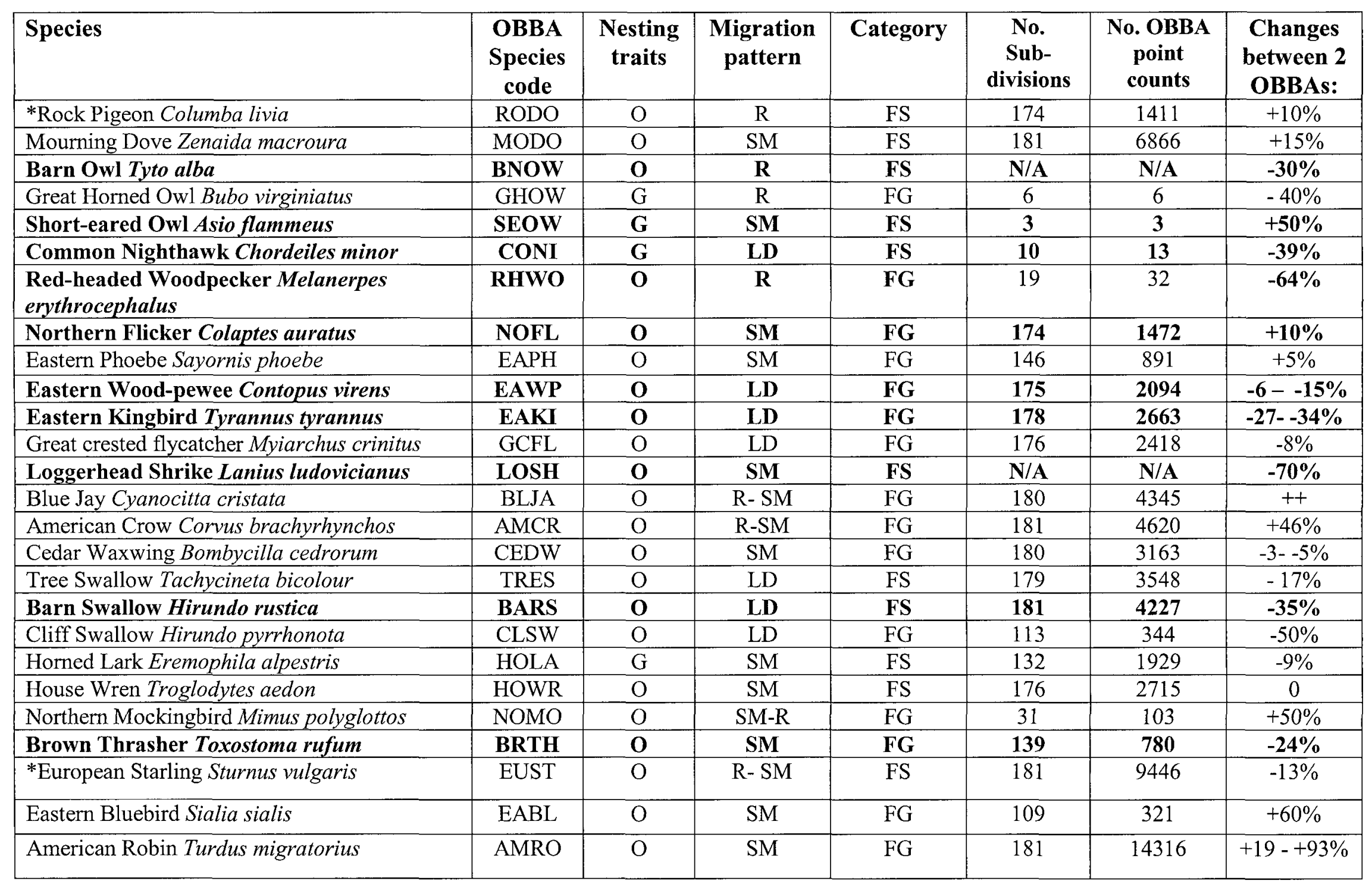




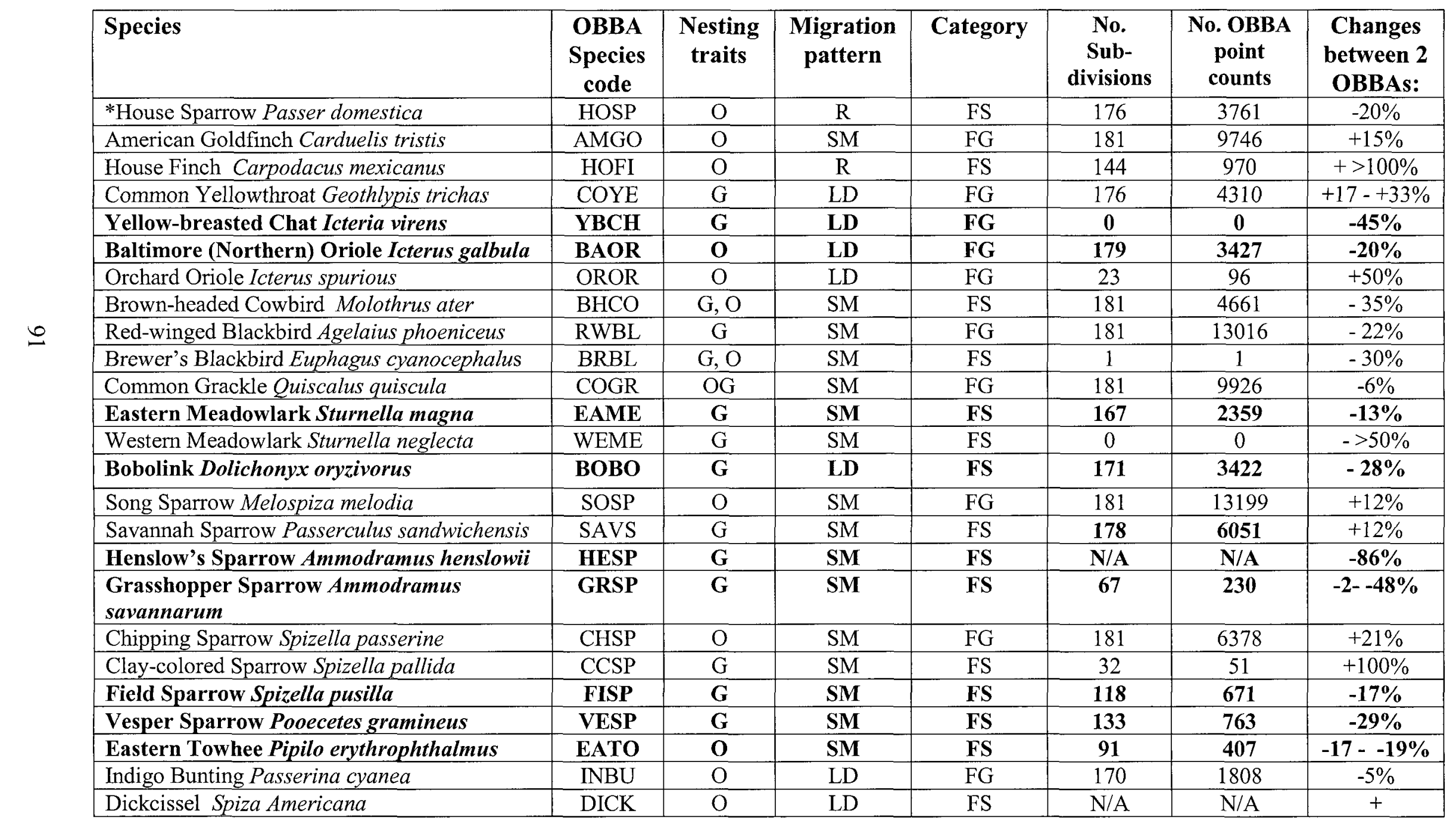


Table A5 Regression results for abundance of farmland birds on the final list for Ontario (41 species) using A. 181 subdivisions B. subdivisions with 5-40\% farmland C. subdivisions with 40-60\% farmland and D. subdivisions with 60-94\% farmland. Models presented using proportional partial regression coefficients (PPRC) for each explanatory variable. aR2 is adjusted R square (as a proportion). Base model is the best fitted model (typically lowest AICc) using all explanatory variables. $\triangle \mathrm{AICc}$ $<4$ bolded (as recommended threshold for competing models).

\section{A. Landscapes with 5 to $94 \%$ farmlands (181 subdivisions)}

\begin{tabular}{|c|c|c|c|c|c|c|}
\hline $\begin{array}{c}\text { Response } \\
\text { variable } \\
\text { (No. spp.) }\end{array}$ & Component & Final model with calculated PPRC & $\mathbf{R 2}$ & AICc & $\triangle \mathrm{AICc}$ & $\mathbf{P}$ \\
\hline \multirow{5}{*}{$\begin{array}{l}\text { Row crop } \\
\text { specialists } \\
\text { (6) }\end{array}$} & Composition & $0.95+1.1$ CROP -0.5 FSAP & 0.531 & 26.7 & 7.3 & 0.000 \\
\hline & Configuration & $0.02-0.5$ AVFS + 1.2 AVCRS & 0.239 & 114.2 & 94.8 & 0.000 \\
\hline & Practice & $0.04+0.7$ CTPHA +0.5 PESTIN & 0.331 & 90.7 & 71.3 & 0.000 \\
\hline & Heterogeneity & $1.0-0.8$ SWDIFR & 0.369 & 79.3 & 59.9 & \\
\hline & Base model & $0.2+1.2$ CROP -0.2 SWDICR-0.2TWWP -0.4 FSAP & 0.564 & 19.4 & 0 & 0.000 \\
\hline \multirow{5}{*}{$\begin{array}{l}\text { Pasture } \\
\text { specialists } \\
(12)\end{array}$} & Composition & $0.12+2.7$ TSPP +0.5 CROP +1.0 NPP -0.4 TWWP & 0.46 & 178.1 & 0 & 0.000 \\
\hline & Configuration & $0.4+0.5$ AVFS & 0.04 & 280.3 & 102.2 & 0.007 \\
\hline & Practice & $0.9+0.6$ CTPHA -0.5 PESTIN & 0.06 & 277.6 & 99.5 & 0.002 \\
\hline & Heterogeneity & No significant model & - & - & - & - \\
\hline & Base model & $0.12+2.7$ TSPP +0.7 CROP +1.0 NPP -0.4 TWWP & 0.46 & 178.1 & $\mathbf{0}$ & 0.000 \\
\hline \multirow{5}{*}{$\begin{array}{l}\text { Farmstead } \\
\text { specialists } \\
(12)\end{array}$} & Composition & $4.1+2.4$ CROP -3.7 TWWP +5.0 FSAP & 0.29 & 814.8 & 36.9 & 0.000 \\
\hline & Configuration & $6.5-8.3$ AVFS + 7.3 AVCRS & 0.27 & 822.7 & 44.8 & 0.000 \\
\hline & Practice & $2.6+5.8$ PESTIN & 0.28 & 816.3 & 38.4 & 0.000 \\
\hline & Heterogeneity & $10.0-5.6$ SWDIFR & 0.34 & 801.2 & 23.3 & 0.000 \\
\hline & Base model & 13.3 - 7.5 SWDIFR - 4.4 AVCRS +3.9 FSAP & 0.424 & 777.9 & $\mathbf{0}$ & 0.000 \\
\hline
\end{tabular}




\begin{tabular}{|c|c|c|c|c|c|c|}
\hline \multirow{3}{*}{$\begin{array}{l}\text { Farmland } \\
\text { specialists } \\
(30)\end{array}$} & Composition & $4.5+3.4$ CROP -3.3 TWWP + 4.4 FSAP & 0.33 & 843.6 & 27.6 & 0.000 \\
\hline & Configuration & $6.9+8.6$ AVCRS -8.1 AVFS & 0.24 & 866.1 & 50.1 & 0.000 \\
\hline & Heterogeneity & $11.7-6.3$ SWDIFR & 0.34 & 837.8 & 21.8 & 0.000 \\
\hline \multirow{3}{*}{$\begin{array}{l}\text { Edge farmland } \\
\text { generalists } \\
\text { (11) }\end{array}$} & Composition & $1.9+0.4$ TWWP + 1.3 NPP + 0.5 CROP & 0.127 & 452.0 & 1.3 & 0.000 \\
\hline & Configuration & $2.1+1.1$ AVFS & 0.05 & 466.1 & 15.4 & 0.002 \\
\hline & Base model & $1.6+0.7$ TWWP +1.1 AVCRS +1.0 NPP & 0.134 & 450.7 & $\mathbf{0}$ & 0.000 \\
\hline \multirow{5}{*}{$\begin{array}{l}\text { BCR } 13 \\
\text { priority species } \\
(15)\end{array}$} & Composition & $0.14+2.9$ TSPP +0.5 CROP + $0.8 \mathrm{NPP}-0.45$ TWWP & 0.45 & 220.9 & $\mathbf{0}$ & 0.003 \\
\hline & Configuration & $0.5+0.7$ AVFS & 0.036 & 320.3 & 99.4 & 0.006 \\
\hline & Practice & $1.0+0.7$ CTPHA -0.5 PESTIN & 0.05 & 318.0 & 97.1 & 0.003 \\
\hline & Heterogeneity & $0.5+0.4$ SWDICR & 0.02 & 323.9 & 103.0 & 0.048 \\
\hline & Base model & $0.14+2.9$ TSPP +0.5 CROP + 0.8 NPP -0.45 TWWP & 0.45 & 220.9 & $\mathbf{0}$ & 0.003 \\
\hline
\end{tabular}


Table A5 Regression results for abundance of farmland birds on the final list for Ontario (41 species) using A. 181 subdivisions B. subdivisions with 5-40\% farmland C. subdivisions with 40-60\% farmland and D. subdivisions with $60-94 \%$ farmland. Models presented using proportional partial regression coefficients (PPRC) for each explanatory variable. aR2 is adjusted R square (as a proportion). Base model is the best fitted model (typically lowest AIC) using all explanatory variables. $\triangle \mathrm{AICc}<4$ bolded (as recommended threshold for competing models).

\section{B. Landscapes with 5 to $40 \%$ farmlands ( 59 subdivisions)}

\begin{tabular}{|c|c|c|c|c|c|c|}
\hline $\begin{array}{c}\text { Response } \\
\text { variable } \\
\end{array}$ & Component & Final model with calculated PPRC & $\mathbf{R 2}$ & AICc & $\triangle \mathrm{AICc}$ & $\mathbf{P}$ \\
\hline \multirow{5}{*}{$\begin{array}{l}\text { All farmland } \\
\text { birds } \\
(40)\end{array}$} & Composition & $7.7+12.2$ CROP -7.8 TSPP & 0.44 & 306.7 & 6.7 & 0.000 \\
\hline & Configuration & $13.2-12.1$ AVFS + 9.0 AVCRS & 0.24 & 324.8 & 24.8 & 0.000 \\
\hline & Practice & $8.3+11.9$ PESTIN & 0.21 & 325.8 & 25.8 & 0.000 \\
\hline & Heterogeneity & $22.4-11.0$ SWDIFR & 0.374 & 312.1 & 12.1 & 0.000 \\
\hline & Base model & 22.3 -10.9 SWDIFR +7.2 CROP - 7.8 AVCRS & 0.511 & 300.0 & 0 & 0.000 \\
\hline \multirow{5}{*}{$\begin{array}{l}\text { Row crop } \\
\text { specialists } \\
\text { (6) }\end{array}$} & Composition & $0.037+0.2$ CROP -0.08 TWWP +0.1 SFALP & 0.452 & -160.0 & 0 & 0.000 \\
\hline & Configuration & $0.148-0.18$ AVFS +0.14 AVCRS & 0.188 & -138.1 & 21.9 & 0.001 \\
\hline & Practice & $0.036+0.2$ PESTIN + 0.1 CTPHA & 0.292 & -146.2 & 14.8 & 0.000 \\
\hline & Heterogeneity & $0.28-0.18$ SWDIFR & 0.249 & -144.0 & 16.0 & 0.000 \\
\hline & Base model & $0.037+0.2$ CROP -0.1 TWWP +0.1 SFALP & 0.564 & -160.0 & $\mathbf{0}$ & 0.000 \\
\hline \multirow{5}{*}{$\begin{array}{l}\text { Pasture } \\
\text { specialists } \\
(12)\end{array}$} & Composition & $0.2+0.8 \mathrm{NPP}+0.4 \mathrm{CROP}$ & 0.189 & 27.2 & 4.6 & 0.001 \\
\hline & Configuration & No significant model & - & - & - & - \\
\hline & Practice & $0.8-0.4$ FERTIN & 0.084 & 33.1 & 10.5 & 0.015 \\
\hline & Heterogeneity & No significant model & & & & \\
\hline & Base model & $0.44+0.4$ NPP +0.65 CROP -0.6 FERTIN & 0.266 & 22.6 & $\mathbf{0}$ & 0.000 \\
\hline \multirow{5}{*}{$\begin{array}{l}\text { Farmstead } \\
\text { specialists } \\
(12)\end{array}$} & Composition & $3.7+7.6$ CROP -3.9 TWWP -4.2 TSPP & 0.443 & 271.3 & 17.7 & 0.000 \\
\hline & Configuration & $6.3-9.7$ AVFS +6.9 AVCRS & 0.285 & 284.7 & 31.1 & 0.000 \\
\hline & Practice & $2.1+10.7$ PESTIN & 0.301 & 282.1 & 28.5 & 0.000 \\
\hline & Heterogeneity & $14.0-9.2$ SWDIFR & 0.501 & 263.2 & 9.6 & 0.000 \\
\hline & Base model & 18.8 -12.0 SWDIFR -6.8 AVCRS +3.3 FSAP & 0.587 & 253.6 & $\mathbf{0}$ & 0.000 \\
\hline Farmland & Composition & $4.1+7.9$ CROP -4.0 TWWP - 3.7 TSPP & 0.445 & 272.7 & 13.4 & 0.000 \\
\hline
\end{tabular}




\begin{tabular}{|c|c|c|c|c|c|c|}
\hline $\begin{array}{c}\text { Response } \\
\text { variable }\end{array}$ & Component & Final model with calculated PPRC & $\mathbf{R 2}$ & AICc & $\triangle \mathrm{AICc}$ & $\mathbf{P}$ \\
\hline \multirow{4}{*}{$\begin{array}{l}\text { specialists } \\
\text { (30) }\end{array}$} & Configuration & $6.9-10.6$ AVFS + 6.8 AVCRS & 0.279 & 286.9 & 28.1 & 0.000 \\
\hline & Practice & $2.8+10.7$ PESTIN & 0.283 & 285.3 & 26.5 & 0.000 \\
\hline & Heterogeneity & $14.5-9.0$ SWDIFR & 0.461 & 268.4 & 9.6 & 0.000 \\
\hline & Base model & 16.6-10.0 SWDIFR -6.8 AVCRS + 4.0 CROP & 0.562 & 258.8 & $\mathbf{0}$ & 0.000 \\
\hline \multirow{5}{*}{$\begin{array}{l}\text { Edge farmland } \\
\text { generalists } \\
\text { (11) }\end{array}$} & Composition & $2.0+1.7$ TWWP & 0.189 & 148.8 & 8.6 & 0.000 \\
\hline & Configuration & No significant model & & & & \\
\hline & Practice & $3.4-1.2$ FERTIN & 0.080 & 156.2 & 16.0 & 0.017 \\
\hline & Heterogeneity & No significant model & & & & \\
\hline & Base model & $2.2+2.2$ TWWP +3.3 AVCRS -1.8 FERTIN - 1.8 AVFS & 0.344 & 140.2 & $\mathbf{0}$ & 0.000 \\
\hline \multirow{5}{*}{$\begin{array}{l}\text { BCR } 13 \\
\text { priority species } \\
\text { (15) }\end{array}$} & Composition & $0.44+0.72 \mathrm{NPP}$ & 0.127 & 34.3 & 0 & 0.003 \\
\hline & Configuration & No significant model & & & & \\
\hline & Practice & $0.8-0.4$ FERTIN & 0.084 & 37.1 & 2.8 & 0.015 \\
\hline & Heterogeneity & No significant model & & & & \\
\hline & Base model & $0.44+0.72$ NPP & 0.127 & 34.3 & $\mathbf{0}$ & 0.003 \\
\hline
\end{tabular}


Table A5 Regression results for abundance of farmland birds on the final list for Ontario (41 species) using A. 181 subdivisions B. subdivisions with 5-40\% farmland C. subdivisions with 40-60\% farmland and D. subdivisions with $60-94 \%$ farmland. Models presented using proportional partial regression coefficients (PPRC) for each explanatory variable. aR2 is adjusted R square (as a proportion). Base model is the best fitted model (typically lowest AIC) using all explanatory variables. $\triangle \mathrm{AICc}<4$ bolded (as recommended threshold for competing models).

\section{Landscapes with 40 to $60 \%$ farmlands (54 subdivisions)}

\begin{tabular}{|c|c|c|c|c|c|c|}
\hline $\begin{array}{c}\text { Response } \\
\text { variable }\end{array}$ & Component & Final model with calculated PPRC & $\mathbf{R 2}$ & AICc & $\triangle \mathrm{AICc}$ & $\mathbf{P}$ \\
\hline \multirow{5}{*}{$\begin{array}{l}\text { All farmland } \\
\text { birds } \\
(41)\end{array}$} & Composition & No significant model & - & - & - & - \\
\hline & Configuration & $15.2-6.3$ AVFS & 0.067 & 300.0 & $\mathbf{0}$ & 0.031 \\
\hline & Practice & No significant model & - & - & - & - \\
\hline & Heterogeneity & No significant model & - & - & - & - \\
\hline & Base model & 15.2-6.3 AVFS & 0.067 & 300.0 & 0 & 0.031 \\
\hline \multirow{5}{*}{$\begin{array}{l}\text { Row crop } \\
\text { specialists } \\
\text { (6) }\end{array}$} & Composition & $0.03+0.12 \mathrm{CROP}$ & 0.117 & -117.7 & 6.5 & 0.006 \\
\hline & Configuration & No significant model & - & - & - & - \\
\hline & Practice & $0.093+0.2$ CTPHA & 0.175 & -121.4 & 2.8 & 0.001 \\
\hline & Heterogeneity & $0.28-0.1$ SWDIFR & 0.08 & -115.4 & 8.8 & 0.021 \\
\hline & Base model & $0.16+0.2$ CTPHA - 0.1 TWWP & 0.234 & -124.2 & 0 & 0.000 \\
\hline \multirow{5}{*}{$\begin{array}{l}\text { Pasture } \\
\text { specialists } \\
(12)\end{array}$} & Composition & $0.47+1.2$ TSPP & 0.217 & 77.5 & $\mathbf{0}$ & 0.000 \\
\hline & Configuration & No significant model & - & - & - & - \\
\hline & Practice & $1.2-1.0$ PESTIN & 0.90 & 85.3 & 7.8 & 0.015 \\
\hline & Heterogeneity & No significant model & - & - & - & - \\
\hline & Base model & $0.47+1.2$ TSPP & 0.217 & 77.5 & $\mathbf{0}$ & 0.000 \\
\hline
\end{tabular}




\begin{tabular}{|c|c|c|c|c|c|c|}
\hline \multirow{4}{*}{$\begin{array}{l}\text { Farmstead } \\
\text { specialists } \\
(12)\end{array}$} & Composition & $3.9-3.4$ TSPP +3.3 FSAP & 0.197 & 244.0 & 0.9 & 0.001 \\
\hline & Configuration & $7.7-5.6$ AVFS & 0.142 & 246.4 & 3.3 & 0.003 \\
\hline & Practice & $3.0+4.0$ PESTIN & 0.075 & 250.5 & 7.4 & 0.024 \\
\hline & Heterogeneity & $8.0-3.0$ SWDIFR & 0.09 & 249.6 & 6.5 & 0.015 \\
\hline \multirow{4}{*}{$\begin{array}{l}\text { Farmland } \\
\text { specialists } \\
(30)\end{array}$} & Composition & $+3.5+3.5$ FSAP & 0.069 & 257.7 & 2.1 & 0.03 \\
\hline & Configuration & $8.6-5.6$ AVFS & 0.104 & 255.6 & $\mathbf{0}$ & 0.009 \\
\hline & Practice & No significant model & - & - & - & - \\
\hline & Base model & $8.6-5.6$ AVFS & 0.104 & 255.6 & $\mathbf{0}$ & 0.009 \\
\hline \multirow{5}{*}{$\begin{array}{l}\text { Edge farmland } \\
\text { generalists } \\
\text { (11) }\end{array}$} & Composition & $+2.4+1.1 \mathrm{NPP}$ & 0.094 & 116.9 & 5.2 & 0.013 \\
\hline & Configuration & No significant model & - & - & - & - \\
\hline & Practice & $3.3-1.8$ PESTIN & 0.176 & 111.7 & 0 & 0.001 \\
\hline & Heterogeneity & $1.7+0.9$ SWDIFR & 0.07 & 118.3 & 6.6 & 0.028 \\
\hline & Base model & 3.3-1.8 PESTIN & 0.176 & 111.7 & 0 & 0.001 \\
\hline \multirow{5}{*}{$\begin{array}{l}\text { BCR } 13 \\
\text { priority species } \\
(15)\end{array}$} & Composition & $+0.53+1.3 \mathrm{TSPP}$ & 0.252 & 79.8 & 0 & 0.000 \\
\hline & Configuration & No significant model & - & - & - & - \\
\hline & Practice & $1.4-1.2$ PESTIN & 0.114 & 89.1 & 9.3 & 0.007 \\
\hline & Heterogeneity & $+0.29+0.6$ SWDIFR & 0.056 & 92.6 & 12.8 & 0.045 \\
\hline & Base model & $+0.53+1.3$ TSPP & 0.252 & 79.8 & 0 & 0.000 \\
\hline
\end{tabular}


Table A5 Regression results for abundance of farmland birds on the final list for Ontario (41 species) using A. 181 subdivisions B. subdivisions with 5-40\% farmland C. subdivisions with 40-60\% farmland and D. subdivisions with $60-94 \%$ farmland. Models presented using proportional partial regression coefficients (PPRC) for each explanatory variable. aR2 is adjusted $\mathrm{R}$ square (as a proportion). Base model is the best fitted model (typically lowest AIC) using all explanatory variables. $\triangle \mathrm{AICc}<4$ bolded (as recommended threshold for competing models).

\section{Landscapes with 60 to $94 \%$ farmlands (68 subdivisions)}

\begin{tabular}{|c|c|c|c|c|c|c|}
\hline $\begin{array}{c}\text { Response } \\
\text { variable }\end{array}$ & Component & Final model with calculated PPRC & $\mathbf{R 2}$ & AICc & $\triangle \mathrm{AICc}$ & $\mathbf{p}$ \\
\hline \multirow{5}{*}{$\begin{array}{l}\text { All farmland } \\
\text { birds } \\
\text { (41) }\end{array}$} & Composition & No significant model & - & - & - & - \\
\hline & Configuration & No significant model & - & - & - & - \\
\hline & Practice & No significant model & - & - & - & - \\
\hline & Heterogeneity & $20.3-5.5$ SWDICR & 0.085 & 355.4 & $\mathbf{0}$ & 0.01 \\
\hline & Base model & 20.3-5.5 SWDICR & 0.085 & 355.4 & $\mathbf{0}$ & 0.01 \\
\hline \multirow{5}{*}{$\begin{array}{l}\text { Row crop } \\
\text { specialists } \\
(6)\end{array}$} & Composition & $-0.53+1.0 \mathrm{CROP}$ & 0.239 & 68.5 & $\mathbf{0}$ & 0.000 \\
\hline & Configuration & No significant model & - & - & - & - \\
\hline & Practice & $0.25+0.6$ PESTIN & 0.056 & 82.9 & 14.4 & 0.03 \\
\hline & Heterogeneity & $1.3-0.9$ SWDIFR & 0.157 & 75.3 & 6.8 & 0.001 \\
\hline & Base model & $-0.53+1.0$ CROP & 0.239 & 68.5 & $\mathbf{0}$ & 0.000 \\
\hline \multirow{5}{*}{$\begin{array}{l}\text { Pasture } \\
\text { specialists } \\
(12)\end{array}$} & Composition & $-0.35+2.2$ TSPP +1.5 NPP +0.6 CROP & 0.554 & 70.1 & $\mathbf{0}$ & 0.000 \\
\hline & Configuration & $0.64+3.7$ AVFS, -3.5 AVCRS & 0.308 & 98.2 & 28.1 & 0.000 \\
\hline & Practice & 3.34 -1.7 PESTIN, -0.6 AMPF & 0.368 & 98.3 & 28.2 & 0.000 \\
\hline & Heterogeneity & $-0.12+1.4$ SWDIFR & 0.239 & 103.4 & 33.3 & 0.000 \\
\hline & Base model & $-0.35+2.2$ TSPP +1.5 NPP +0.6 CROP & 0.554 & 70.1 & $\mathbf{0}$ & 0.000 \\
\hline
\end{tabular}




\begin{tabular}{|c|c|c|c|c|c|c|}
\hline \multirow{5}{*}{$\begin{array}{l}\text { Farmstead } \\
\text { specialists } \\
\text { (12) }\end{array}$} & Composition & $7.9-3.0$ TWWP & 0.082 & 283.9 & 17.9 & 0.011 \\
\hline & Configuration & $8.7-3.3$ AVFS & 0.08 & 285.1 & 19.1 & 0.021 \\
\hline & Practice & $6.2+9.9$ PESTIN, -6.7 FERTIN & 0.221 & 274.1 & 8.1 & 0.000 \\
\hline & Heterogeneity & 12.4-3.6 SWDICR, -2.8 SWDIFR & 0.187 & 276.9 & 10.9 & 0.000 \\
\hline & Base model & 9.5 +9.4 PESTIN - 3.5 SWDICR - 5.0 FERTIN & 0.322 & 266.0 & $\mathbf{0}$ & 0.000 \\
\hline \multirow{5}{*}{$\begin{array}{l}\text { Farmland } \\
\text { specialists } \\
\text { (30) }\end{array}$} & Composition & $9.5-3.0$ TWWP & 0.058 & 305.0 & 9.3 & 0.028 \\
\hline & Configuration & No significant model & - & - & - & - \\
\hline & Practice & $8.8+9.4$ PESTIN, -7.6 FERTIN & 0.117 & 301.9 & 6.2 & 0.007 \\
\hline & Heterogeneity & $13.1-4.4$ SWDICR & 0.122 & 300.3 & 4.6 & 0.002 \\
\hline & Base model & 15.0 -4.6 SWDICR- 3.0 TWWP & 0.196 & 295.7 & $\mathbf{0}$ & 0.000 \\
\hline \multirow{5}{*}{$\begin{array}{l}\text { Edge farmland } \\
\text { generalists } \\
\text { (11) }\end{array}$} & Composition & $2.7+2.0 \mathrm{NPP}$ & 0.131 & 178.3 & 1.8 & 0.002 \\
\hline & Configuration & No significant model & - & - & - & - \\
\hline & Practice & 4.7-1.2 CTPHA - 1.4 FERTIN & 0.150 & 178.0 & 1.5 & 0.002 \\
\hline & Heterogeneity & No significant model & - & - & - & - \\
\hline & Base model & $3.2+1.6$ NPP - 1.0 CTPHA & 0.170 & 176.5 & $\mathbf{0}$ & 0.001 \\
\hline \multirow{5}{*}{$\begin{array}{l}\text { BCR } 13 \\
\text { priority species } \\
\text { (15) }\end{array}$} & Composition & $-0.41+2.2 \mathrm{TSPP}+1.8 \mathrm{NPP}+0.7 \mathrm{CROP}$ & 0.495 & 99.6 & $\mathbf{0}$ & 0.000 \\
\hline & Configuration & $0.7+4.1$ AVFS, -3.7 AVCRS & 0.273 & 122.7 & 23.1 & 0.001 \\
\hline & Practice & 4.0-1.9 PESTIN - 0.7 AMPF & 0.364 & 113.7 & 14.1 & 0.000 \\
\hline & Heterogeneity & $0.012+1.6$ SWDIFR & 0.221 & 126.1 & 26.5 & 0.001 \\
\hline & Base model & $-0.41+2.2 \mathrm{TSPP}+1.8 \mathrm{NPP}+0.7 \mathrm{CROP}$ & 0.495 & 99.6 & $\mathbf{0}$ & 0.000 \\
\hline
\end{tabular}

